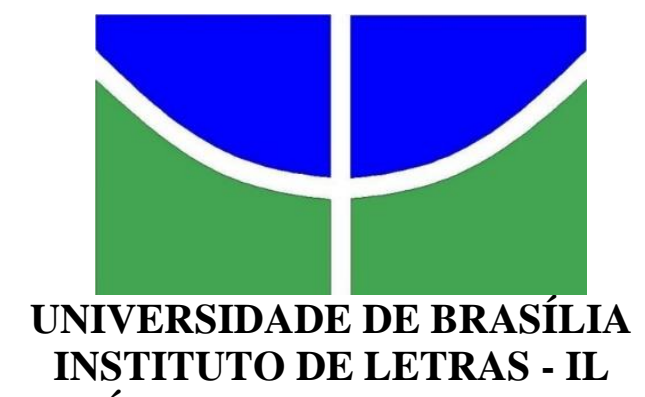

DEPARTAMENTO DE LÍNGUAS ESTRANGEIRAS E TRADUÇ̃̃O - LET PROGRAMA DE PÓS-GRADUAÇÃO EM LINGUÍSTICA APLICADA - PGLA

HELP ME TO HELP US:

\title{
PEER COACHING COMO FERRAMENTA PARA A FORMAÇÃO CONTINUADA DO PROFESSOR DE INGLÊS COMO LÍNGUA ESTRANGEIRA
}

\author{
BERND RENNER
}

DISSERTAÇÃO DE MESTRADO EM LINGUÍSTICA APLICADA 
BERND RENNER

HELP ME TO HELP US:

PEER COACHING COMO FERRAMENTA PARA A FORMAÇÃO CONTINUADA DO PROFESSOR DE INGLÊS COMO LÍNGUA ESTRANGEIRA

Dissertação apresentada ao Programa de PósGraduação em Linguística Aplicada da Universidade de Brasília, como parte dos requisitos para a obtenção do título de Mestre em Linguística Aplicada.

Orientador:

Prof. Dr. Augusto César Luitgards Moura Filho 


\section{BERND RENNER}

HELP ME TO HELP US:

PEER COACHING COMO FERRAMENTA PARA A FORMAÇÃO

CONTINUADA DO PROFESSOR DE

INGLÊS COMO LÍNGUA ESTRANGEIRA

Dissertação defendida e aprovada em 06 de novembro de 2015, como requisito parcial para a obtenção do título de Mestre em Linguística Aplicada, do Instituto de Letras da Universidade de Brasília.

BANCA EXAMINADORA

Prof. Dr. Augusto César Luitgards Moura Filho - Universidade de Brasília (Orientador e Presidente)

Profa. Dra. Laura Stella Miccoli - Universidade Federal de Minas Gerais (Examinadora Externa)

Profa. Dra. Gladys Quevedo-Camargo - Universidade de Brasília (Examinadora Interna)

Profa. Dra. Lúcia Maria de Assunção Barbosa - Universidade de Brasília (Examinadora Suplente) 


\section{AGRADECIMENTOS}

Gostaria de agradecer ao meu orientador, Professor Doutor Augusto César Luitgards Moura Filho, pelo acolhimento, pela sua generosidade de compartilhar conhecimentos, pelo estímulo durante o curso e pela orientação segura e pontual, tão fundamentais para a realização desta dissertação.

Gostaria de agradecer a todos os professores do PPGLA da Universidade de Brasília UnB, com os quais tive a honra de compartilhar conhecimento e aprender. Também agradeço a todos os funcionários da secretaria do programa pela atenção e apoio.

As professoras participantes desta pesquisa da UnB Idiomas e todos os que contribuíram de alguma forma para o desenvolvimento deste trabalho, também meus sinceros agradecimentos.

Agradeço, também, o apoio da CAPES, pela concessão da bolsa do Programa de Mestrado.

Aos meus pais e meus irmãos na Alemanha, sou imensamente grato.

Gostaria de agradecer a todos meus amigos os quais tive a honra de conhecer, desde a minha primeira chegada, ao Brasil, em 2011. Agradeço muito a cada um de vocês por me fazerem sentir em casa. Considero todos vocês meus irmãos, minha família brasileira. Obrigado pelo apoio constante. Obrigado pela amizade tão preciosa. 


\section{RESUMO}

O objetivo do presente estudo é investigar quais contribuições a implementação de um programa de peer coaching como ferramenta para a educação continuada exerce sobre o processo de desenvolvimento profissional no fazer pedagógico de professores de inglês. As práticas de coaching para uma formação colaborativa estão ganhando uma importância crescente em contextos educacionais. Contudo, o peer coaching como subcategoria do coaching ainda é um conceito pouco conhecido: o status de igualdade entre os colegas professores, o caráter não-avaliativo e o fato de que os participantes estão em controle do processo distanciam esse processo formativo das formas mais tradicionais de coaching. A pesquisa envolve tópicos tais como a formação inicial de professores de línguas no Brasil (PIMENTA, 2005; PAIVA, 2005), o professor reflexivo (SCHÖN, 1983; ALARCÃO, 2004) e a formação continuada de professores de línguas (CELANI, 2009; STURM, 2011). Os autores que dão suporte à seção sobre coaching são Gornall e Burn (2013) e Clutterbuck (2010), assim como, também, Showers e Joyce (1996) e Robbins (1991) para a seção sobre o peer coaching. Trata-se de uma pesquisa de caráter interpretativista na modalidade pesquisa-ação, caraterizando-se como um estudo qualitativo (CHIZZOTTI, 2006; DENZIN e LINCOLN, 2006). Os registros da pesquisa foram coletados por meio de um questionário inicial, entrevistas semi-estruturadas gravadas, notas de campo e um diário dialogado. Ao adotar uma abordagem interpretativista, procurei responder às perguntas de pesquisa, apontando possibilidades de como um programa de peer coaching pode ser utilizado na perspectiva reflexiva do ensino de inglês, ao mesmo tempo em que resumo as opiniões das professoras participantes em relação a esse processo formativo alternativo. Os resultados da pesquisa indicam que as atividades colaborativas promoveram a geração e a transferência de conhecimento entre as participantes e, assim, promoveram o crescimento profissional de ambas. Indico, também, possíveis estudos futuros sobre peer coaching, explorando novos caminhos desse conceito para uma formação continuada de professores em serviço.

Palavras-chave: Peer coaching. Formação continuada de professores. Ensino de inglês. 


\begin{abstract}
This paper investigates the contributions that the implementation of a peer coaching program, as a tool for continuing education, has on the process of professional development in the pedagogical practice of English teachers. Coaching practices for collaborative formation are gaining importance in educational contexts. However, peer coaching as a subcategory of coaching is still a not very well-known concept; the equal status of the teacher colleagues, its non-evaluative character and the fact that participants are in control of the process distinguish this formation procedure from other more traditional forms of coaching. The paper reviews topics such as the initial training of language teachers in Brazil (PIMENTA, 2005; PAIVA, 2005), the reflexive teacher (SCHÖN, 1983; ALARCÃO, 2004) and the continuing education of language teachers (CELANI, 2009; STURM, 2011). The authors that support the section on coaching are Gornall and Burn (2013) and Clutterbuck (2010), followed by Showers and Joyce (1996) and Robbins (1991) for the section on peer coaching. This is an interpretive study in the modality of action research, characterized as a qualitative study (CHIZZOTTI, 2006; DENZIN e LINCOLN, 2006). Research records were collected by means of an initial questionnaire, recorded semi-structured interviews, field notes and a discoursed diary. By adopting an interpretive approach, I sought to answer the research questions, pointing out possibilities of how a peer coaching program can be used in a reflexive perspective of teaching English. The results of the research indicate that the collaborative activities promote the generation and transfer of knowledge between participants, thereby supporting the professional growth of both. At the same time I summarize the opinions of the participating teachers in relation to this alternative formation procedure. I also indicate possible future studies on peer coaching that explore new ways of this concept for a continuous formation of teachers in service.
\end{abstract}

Keywords: Peer coaching. Continuing formation of teachers. English teaching. 


\section{LISTA DE FIGURAS}

Figura 1 Responsabilidades Para o Peer Coaching............................................... 46

Figura 2 A Espiral Pesquisa-ação....................................................................... 62 


\section{CONVENÇÕES DE TRANSCRIÇÕES}

(MARCUSCHI, 2003)

$\begin{array}{cl}(+) & \text { Pausa breve } \\ (++) & \text { Pausa média } \\ (+++) & \text { Pausa longa } \\ ((\text { comentário })) & \text { Comentário do pesquisador } \\ \text { ““ } & \text { Citação, discurso indireto ou referência a outras falas } \\ \text { MAIÚSCULA } & \text { Ênfase } \\ \text { Itálico } & \text { Palavra em língua estrangeira } \\ {[\ldots]} & \text { Supressão de trecho }\end{array}$




\section{SUMÁRIO}

1 INTRODUÇÃO......................................................................................................... 11

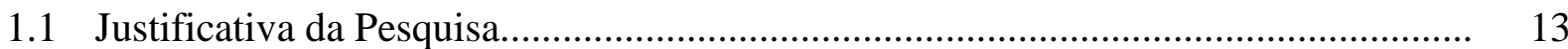

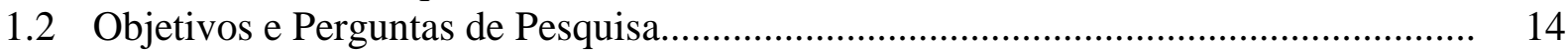

1.3 Referencial Teórico da Pesquisa..................................................................... 14

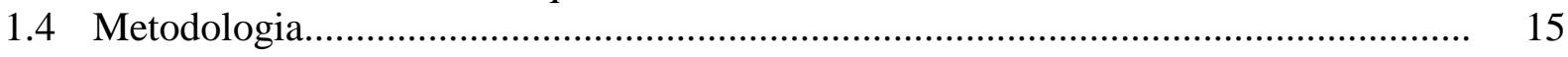

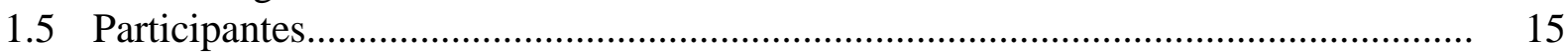

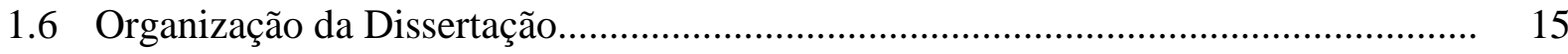

2 FUNDAMENTAÇÃO TEÓRICA..................................................................................... 17

2.1 A Formacão Inicial de Professores de Línguas (Inglês) no Brasil............................ 17

2.1.1 Uma breve história.............................................................................. 17

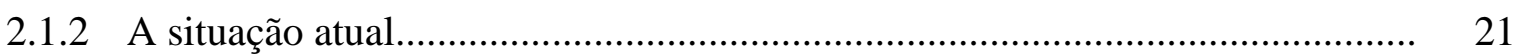

2.1.3 O professor reflexivo......................................................................... 27

2.2 A Formação Continuada de Professores no Brasil ............................................... 36

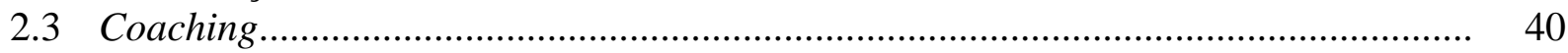

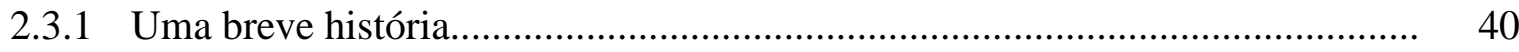

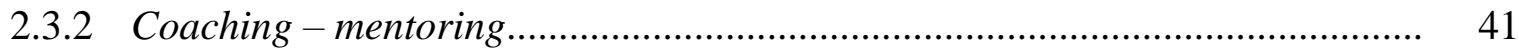

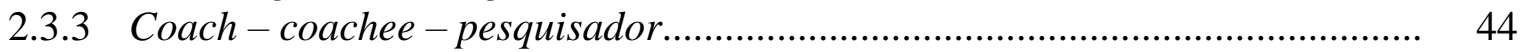

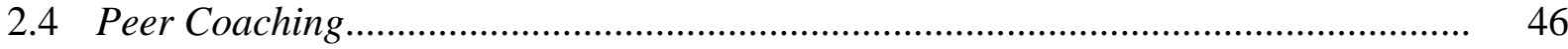

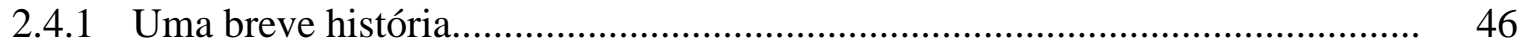

2.4.2 Modalidades do peer coaching ................................................................... 48

2.4.3 Operacionalizações do peer coaching ....................................................... 49

2.4.4 As contribuições do peer coaching............................................................ 51

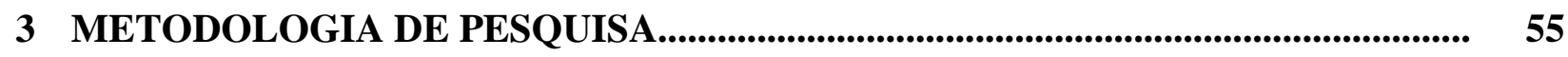

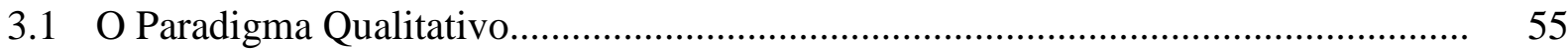

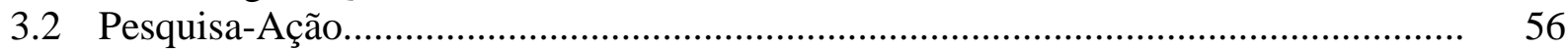

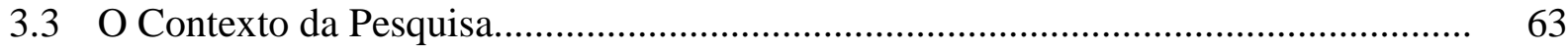

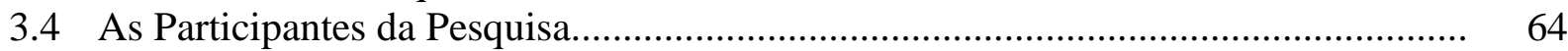

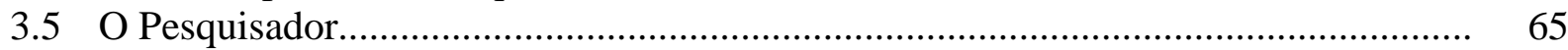

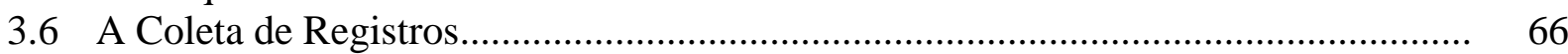

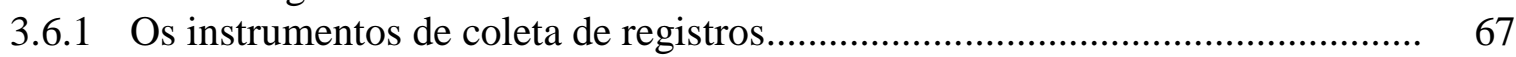

3.6.1.1 Questionário............................................................................ 68

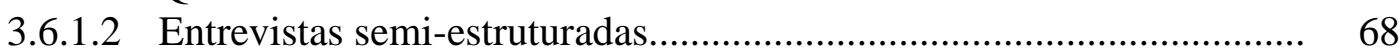

3.6.1.3 Notas de campo....................................................................... 69

3.6.1.4 O diário dialogado..................................................................... $\quad 70$

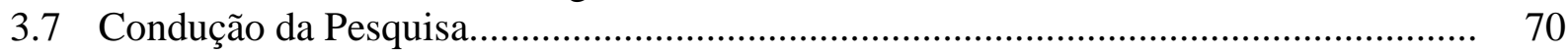

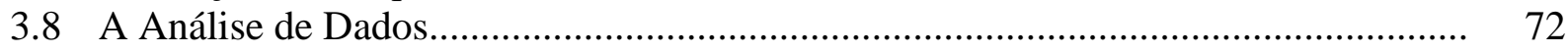

4 APRESENTAÇÃO E ANÁLISE DE DADOS ......................................................... 76

4.1 Revelações...................................................................................................... 76

4.1.1 Motivação Inicial em Relação à Participação no Projeto e às Expectativas dos Participantes. 
4.1.2 As primeiras impressões do pesquisador.................................................. 78

4.1.3 Formação de professores no Brasil............................................................ 78

4.1.3a Formação inicial das professoras.............................................................. 79

4.1.3b Formação continuada......................................................................... 80

4.1.3c Percepção da situação atual dos professores no Brasil..................................... 81

4.1.3d A reflexão crítica (no início/ao longo do projeto)....................................... 82

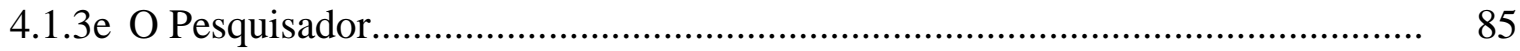

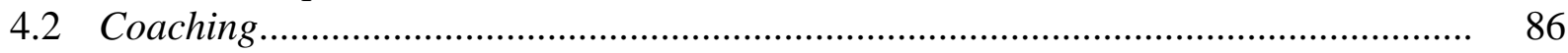

4.2.1 Associações espontâneas e experiências..................................................... 86

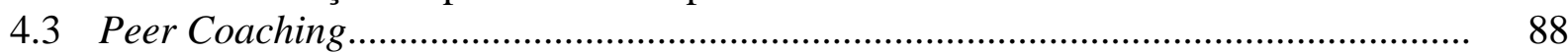

4.3.1 Atividades de peer coaching ................................................................. 88

4.3.1a Atividades realizadas durante as sessões de coaching

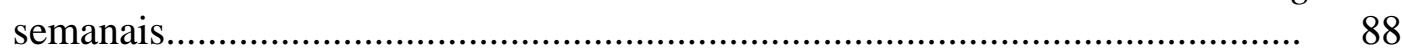

4.3.1b Atividades realizadas fora das sessões de coaching

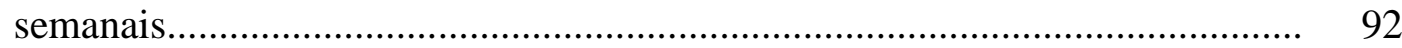

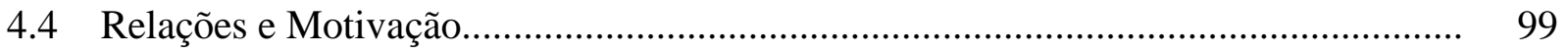

4.4.1 Relações participante/participante, participantes/pesquisador.......................... 99

4.4.2 Motivação e participação ao longo da pesquisa............................................. 101

4.4.3 Mudanças durante o projeto/especificações dos processos............................... 103

4.4.4 Preocupações sobre as participantes............................................................... 104

4.5 Avaliação das Atividades do Peer coaching/Entrevistas ao longo do Projeto...................................................................................................... 106

4.5.1 Opinião sobre o projeto (após a primeira metade dele).................................. 106

4.5.2 Melhoria das áreas marcadas na roda de coaching (após a primeira metade do projeto)................................................................................................ 107

4.5.3 Diálogo com e feedback do colega (após a primeira metade do projeto)........... 107

4.5.4 Expansão do conhecimento/melhorias/aprendizagem de novas habilidades..... 108

4.5.5 Autoavaliação (disposição/participação) durante o projeto (primeira metade).......

4.5.6 Como as participantes veem os benefícios do peer coaching .......................... 109

4.5.7 O cumprimento das expectativas........................................................... 110

4.5.8 Aspectos que agradam ou não as participantes........................................ 110

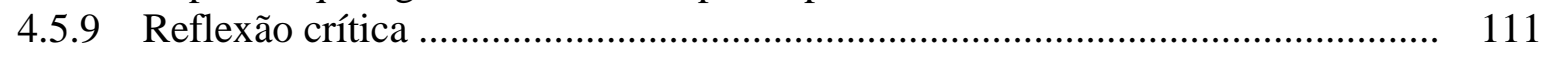

4.5.10 Roda de coaching ............................................................................... 112

4.5.11 Aspectos que fizeram sucesso no peer coaching ......................................... 113

4.5.12 Avaliação das participantes quanto à adequação do peer coaching à formação continuada.

4.5.13 A necessidade e/ou obregatoriedade de peer coaching ..................................... 114

4.5.14 O propósito de refazer ou não outra atividade de peer coaching...................... 115

4.5.15 Avaliação do pesquisador.......................................................................... 116

4.5.16 Avaliação do projeto de peer coaching como um tudo................................... 116

\section{REFLEXÕES FINAIS.}

5.1 Contribuições da Pesquisa.

5.2 Limitações da Pesquisa e Propostas para Estudos Futuros .................................... 121 
Apêndice A Carta-convite à Diretoria da UnB Idiomas

Apêndice B Termo de Consentimento Livre e Esclarecido à Diretoria da UnB

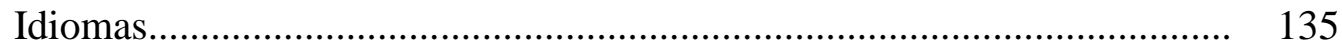

Apêndice C Carta-convite ao (à) Professor(a)............................................................. 136

Apêndice D Termo de Consentimento Livre e Esclarecido para o(a)

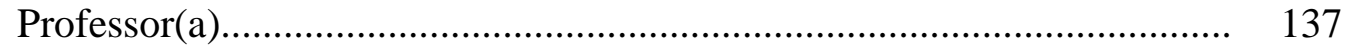

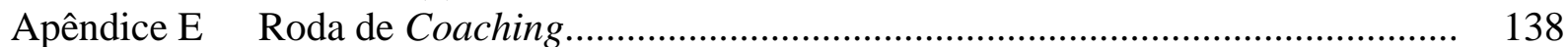

Apêndice F Autoavaliação do Professor........................................................................ 140

Apêndice G Roteiro de Questionário........................................................................... 142

Apêndice H Roteiro da Primeira Entrevista com as Participantes............................... 144

Apêndice I Roteiro da Segunda Entrevista com as Participantes................................. 145

Apêndice J Roteiro da Terceira Entrevista com as Participantes................................. 146

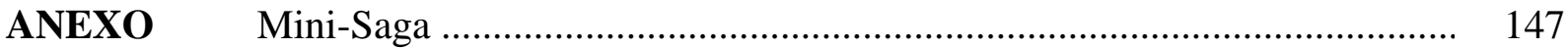




\section{INTRODUÇÃO}

No contexto de ensino/aprendizagem, parece sensato que os docentes tomem iniciativas com foco em melhorar seu desenvolvimento profissional durante suas práticas pedagógicas. Assim, a formação continuada de professores tem sido um assunto amplamente discutido em muitos países do mundo, como atesta o número crescente de publicações sobre o tema.

A pesquisa aqui relatada surgiu exatamente dessa necessidade de crescimento profissional detectada durante minha atividade como professor de inglês. Alguns questionamentos reflexivos sempre me acompanharam na minha atuação docente, tais como quais eram as maneiras mais eficientes que existiam para melhorar o meu trabalho em sala de aula e sobre como eu era percebido pelos meus alunos como professor. Preocupava-me, também, com meu estilo de ensinar línguas e os métodos que eu utilizava, questionando o meu desempenho docente em relação às necessidades dos meus alunos.

Por fim, percebi que essas questões não me eram exclusivas, mas sim partilhadas por colegas de trabalho, com muita frequência. Esse compartilhamento de dúvidas foi importante para buscar como essas questões poderiam ser solucionadas. O que me remeteu a Knight (2011), que também considera importante práticas colaborativas para uma formação continuada de professores a fim de melhorar e desenvolver suas vidas profissionais.

Ao desenvolver esta pesquisa no Brasil, busquei compreender quais eram os aspectos que os autores identificavam para melhoria tanto na formação inicial de professores no Brasil (PAIVA, 2005; CELANI, 2009; VIEIRA ABRAHÃO, 2009), quanto na educação continuada (PIMENTA, 2005; GATTI, 2008; MOURA FILHO, 2011), mais especificamente a formação reflexiva (ZEICHNER, 1993; ALMEIDA FILHO, 1993, 1995; SCHÖN, 1983, 1987, 1992). A partir desse levantamento inicial, foi possível perceber que o coaching (BARKLEY, 2005; CLUTTERBUCK, 2010; GORNALL e BURN, 2013) na modalidade de peer coaching ${ }^{1}$ (ROBBINS, 1991; SHOWERS e JOYCE, 1996; GOTTESMAN, 2000) apresentou-se como alternativa capaz de potencializar as melhorias no ensino de línguas a partir dos esforços dos professores no sentido da profissionalização permanente.

\footnotetext{
${ }^{1}$ Orientação entre pares (esta e as demais traduções desta dissertação são de minha autoria)
} 
Nesse levantamento inicial de pesquisa, também observei que a bibliografia brasileira sobre o coaching ainda não é robusta e, de acordo com o que pesquisei, inferi que o coaching ainda é um assunto muito novo enquanto estratégia de educação continuada no Brasil. Portanto, entendo que a pesquisa relatada aqui pode trazer uma contribuição significativa a esse tema.

Contudo, o próprio conceito de coaching já se apresenta de forma bastante interessante para a educação. Segundo Araújo (1999), o coaching envolve um coach, que é a pessoa que dá apoio a um coachee, sendo essa última a pessoa que quer alcançar um determinado objetivo. Esse procedimento implica o desenvolvimento da autoconscientização do coachee (CLUTTERBUCK, 2010), a reflexão sobre o ensino desenvolvido (BARKLEY, 2005) bem como o uso de feedback e o questionamento eficaz (LANDSBERG, 1996), entre outros.

Dentro da estratégia de coaching, existem outras formas de ação como o peer coaching, que compreende a colaboração de colegas professores, como no caso da pesquisa aqui relatada, a fim de melhorar e expandir seus conhecimentos profissionais (ROBBINS, 1991). Em comparação com as formas tradicionais de coaching, o peer coaching, aplicado à educação estabelece um status de igualdade entre os professores e remove a importante dimensão de poder entre os participantes (SIEGEL, 2000). Vale ressaltar que as atividades são realizadas de forma não-avaliativa e o professor coachee também controla o processo por não ser hierárquico e, sim, colaborativo (BARTH, 2000).

O peer coaching como forma de educação continuada de professores, com origem nos Estados Unidos, ainda é um conceito pouco pesquisado na área de educação no Brasil. Sendo assim, a pesquisa aqui relatada propõe aprofundar um pouco mais esse assunto, por compreender o grande potencial de desenvolvimento profissional continuado que a área oferece. Ademais, o êxito do peer coaching em outros contextos de educação, mesmo não brasileiros, demonstra a sua validade na formação continuada de professores, inclusive o de línguas, que propõe uma educação colaborativa e baseada na prática e experiência pedagógica dos pares.

O desejo de explorar novas formas para uma formação continuada de professores, juntamente com o interesse para iniciar uma tentativa de melhorar a minha própria prática como professor de inglês, motivou-me a voltar-me para a vida acadêmica e escrever esta dissertação sobre peer coaching, o que se alinha bem com a seguinte motivação acadêmica: ajudar outros professores a melhorarem o ensino e a aprendizagem de línguas. 


\subsection{Justificativa da Pesquisa}

Desencadeado por mudanças sociais e uma crise da escola durante os anos 80 e 90, uma discussão sobre o profissionalismo dos professores surgiu em escala global. Com base nessa ideia de desenvolvimento, as primeiras proposições para uma formação continuada de professores começaram a influenciar as políticas em alguns países da Europa e das Américas (TEDESCO; FANFANI, 2004).

Em relação à educação no Brasil, Telles (2009, p.10-11) destaca a necessidade absoluta de uma formação continuada de professores de línguas:

[...] a educação continuada, particularmente relevante em um contexto educacional no qual a formação inicial na área de línguas, especialmente estrangeiras, é praticamente inexistente. A falta de políticas eficazes de ensino de língua estrangeira no país, da qual decorre o mito que "língua estrangeira não se aprende na escola", a qualidade insatisfatória dos programas de formação inicial inerente à licenciatura não só dupla mas, em muitos casos, curta fazem da formação continuada do professor de língua estrangeira uma necessidade premente.

Sendo assim, desde os anos 90, o governo brasileiro vem realizando vários esforços, a fim de melhorar essa situação, que serão apresentados no decorrer deste trabalho.

Contudo, Vezub (2007) relata que essas iniciativas são feitas de modo isolado e pontual e com curta duração. Além disso, as propostas estão focadas no professor individualmente, sem considerar o grupo, nem o seu atual estágio de desenvolvimento profissional, nem os contextos institucionais. O autor também aponta a falta de avaliação e monitoramento sistemáticos em relação às ações implementadas. Tais fatos provocam, por exemplo, a descontinuidade das políticas públicas.

Dessa forma, estudos que investigam e discutem formas diferentes de formação continuada de professores são relevantes, pois podem proporcionar novas possibilidades para docentes de línguas, para que possam refletir continuamente sobre suas práticas atuais.

Assim, estudos que lidam com coaching e outras formas colaborativas de aprendizagem e ensino, mesmo ainda recentes, merecem uma maior atenção por parte dos pesquisadores, pois, no contexto de formação continuada de professores, o peer coaching, como estratégia para o desenvolvimento da atividade de ensino de línguas, tem alto potencial, já que trabalha de maneira interpessoal e envolve dois ou mais professores. 
O peer coaching, como modalidade do coaching no sentido tradicional, é um conceito relativamento novo, mesmo na literatura internacional e, já durante as minhas primeiras investigações, não encontrei literatura em português disponível em relação a esse tema.

Contudo, várias pesquisas tratando do coaching/mentoring no contexto da formação continuada têm sido realizadas no Brasil, como, por exemplo, os estudos de Nogueira (2011) e Cunha (2014). Ainda assim, não encontrei qualquer tipo de pesquisa que desse enfoque ao peer coaching, ou seja, não há pesquisa voltada para o uso do peer coaching no ensino de línguas que tenha sido aplicada numa instituição brasileira, o que foi uma motivação adicional para eu assumir esse desafio.

\subsection{Objetivos e Perguntas de Pesquisa}

Na pesquisa relatada nesta dissertação, propus a estratégia do peer coaching no fazer pedagógico de professores de inglês como ferramenta para a educação continuada, buscando investigar as contribuições que esse programa traz ao processo de desenvolvimento profissional. A fim de orientar minha pesquisa, estabeleci como objetivos específicos:

1) investigar como um programa de peer coaching pode ser utilizado na perspectiva reflexiva do ensino de inglês;

2) apresentar as opiniões das professoras participantes do peer coaching em relação a esse processo formativo.

A partir desses objetivos propostos, este trabalho tem como objetivo responder as seguintes perguntas de pesquisa:

1) Como um programa de peer coaching pode ser utilizado na perspectiva reflexiva do ensino de inglês?

2) Quais as opiniões das professoras participantes do peer coaching em relação a esse processo formativo?

\subsection{Referencial Teórico da Pesquisa}

O construto teórico dessa pesquisa consiste em duas partes:

A primeira, a fundamentação teórica, trata da formação de professores de línguas. Os principais autores que dão suporte a essa seção são Pimenta (2005), Monteiro (2011), Silva (2013), Moura Filho (2011), Paiva (2005; 2006) e Barcelos (2011). Seguem depois a noção de 
professor reflexivo (DEWEY, 1958; ZEICHNER, 1993; SCHÖN 1983, 1987, 1992; BARTLETT, 1990; ALARCÃO 2004; PRABHU, 1990, entre outros) e a formação continuada de professores no Brasil (CELANI, 2009; GATTI, 2008; STURM, 2011; MOURA FILHO, 2011; NÓVOA, 1991, entre outros). A seção seguinte trata do conceito de coaching apoiada principalmente por autores como Gornall e Burn (2013), Clutterbuck (2010) e Barkley (2005). Finalmente, os autores que dão suporte à última seção dessa primeira parte do peer coaching são principalmente Showers e Joyce (1996), Robbins (1991) e Gottesman (2000).

A segunda parte, metodologia da pesquisa, é baseada em dois conceitos fundamentais: pesquisa qualitativa e pesquisa-ação. A pesquisa qualitativa baseia-se nas obras de autores como Duff (2002), Chizzotti (2006), Denzin e Lincoln (1994, 2006) e Erickson (1986). Já a pesquisa-ação é guiada principalmente por autores como El Andaloussi (2004), Cohen, Manion e Morrison (2011), Denzin e Lincoln (1994), Freebody (2003), Koshy (2005) e Kemmis e McTaggart (2000). Essa parte é composta, também, por base bibliográfica para a análise de dados, que teve como referências principalmente os textos de Bogdan e Biklen (1998) e Richardson (1994).

\subsection{Metodologia}

A pesquisa é de caráter interpretativista, na modalidade pesquisa-ação, e se propõe a responder as perguntas da melhor maneira possível, caraterizando-se como uma pesquisa qualitativa conforme abordam Chizzotti (2006) e Denzin e Lincoln (2006).

\subsection{Participantes}

As participantes da pesquisa são duas professoras de inglês da UnB Idiomas de Brasília, Brasil, que trabalham nessa instituição há vários anos.

\subsection{Organização da Dissertação}

Esta dissertação está dividida em cinco capítulos. O primeiro capítulo apresenta uma introdução que mostra meu interesse pelo tema, seguido pela justificativa e a contextualização 
da pesquisa. A seguir, apresento os objetivos gerais e específicos, bem como as questões nas quais a pesquisa está fundamentada e a metodologia adotada.

No segundo capítulo, delineio a fundamentação teórica da pesquisa, que abrange as seguintes partes: A formação inicial de professores de inglês no Brasil, O professor reflexivo, A formação continuada de professores de inglês no Brasil, coaching e peer coaching.

O terceiro capítulo explicita a metodologia de pesquisa adotada, os instrumentos utilizados para a coleta e análise de dados, bem como o contexto e as participantes do estudo.

No quarto capítulo, analiso e discuto os dados coletados em campo. Procurei uma avaliação e interpretação das minhas observações no presente estudo, estando ciente da subjetividade em relação à interpretação dos dados, por tratar-se de um estudo qualitativo interpretativista.

Nas considerações finais, retomo novamente vários aspectos da investigação como um todo. Nessa seção volto, com base nos dados apresentados no quarto capítulo, às perguntas de pesquisa a fim de apresentar os resultados obtidos, ao mesmo tempo mostrando as possíveis limitações do estudo no contexto atual.

No quinto e último capítulo, retomo e respondo as perguntas de pesquisa, aponto as contribuições delas, indico suas limitações e faço propostas para estudos futuros sobre o tema aqui abordado. 


\section{FUNDAMENTAÇÃO TEÓRICA}

Este capítulo tem como objetivo descrever as teorias relevantes que fundamentam a pesquisa relatada neste texto. Primeiramente, apresento a Formação Inicial de Professores de Línguas (Inglês) no Brasil, para depois traçar considerações acerca da Formação Continuada de Professores. A seção a seguir descreve o conceito de Coaching e, em seguida, discorro sobre o Peer Coaching.

\subsection{A Formacão Inicial de Professores de Línguas (Inglês) no Brasil}

\subsubsection{Uma breve história}

A fim de compreender a situação atual em relação à formação inicial de professores de línguas no Brasil, é necessário contemplar o desenvolvimento dela, ao longo de um recorte histórico.

O início dos esforços para uma formação inicial sistemática dos professores no Brasil aconteceu somente em 1930, com a criação do Ministério da Educação e Saúde Pública, sob a responsibilidade do ministro Francisco de Campos, tendo como medida de reforma educacional criar o Estatuto Básico das Universidades Brasileiras que instituiu, em 1934, a Faculdade de Filosofia, Ciências e Letras, em São Paulo (CHAGAS, 1979).

Com o seu principal foco direcionado para a formação de professores, essa nova instituição criou uma formação homogênea para professores do Ginásio, do Colégio e o Ensino Normal, que consistia de três anos de estudos específicos na área da especialização e mais um ano de curso, a fim de, finalmente, obter a licenciatura, que constitui o modelo atual da formação de professores no Brasil (VICENTI; LUGLI, 2009).

Nos anos seguintes, o ensino de línguas experimentou uma crescente relevância, não menos importante devido à Reforma Capanema, em 1942, e às mudanças conduzidas no sistema educacional brasileiro. As medidas dessa reforma, no que diz respeito ao ensino do inglês no Ensino Secundário, consistiram, por um lado, em torná-lo uma disciplina obrigatória no Ginásio e no Colegial e, por outro, no aumento da carga horária para 12 horas semanais (HELB 1, 2015).

A formação de professores após a segunda Guerra Mundial e ainda nos anos de 1960/70, influenciada por reformas políticas, econômicas e sociais, foi realizada sob o 
paradigma positivista, com "currículos pautados no domínio de habilidades apontadas pelas pesquisas como imprescindíveis ao bom professor e na capacidade de reproduzir técnicas e atividades em sala de aula" (CAVALCANTI; MOITA LOPES, 1991, p.114).

Em 1961, a primeira Lei de Diretrizes e Bases da Educação (doravante LDB) entrou em vigor, com o objetivo de regularizar o sistema educacional brasileiro. Como consequência, a obrigatoriedade existente para o ensino de inglês foi retirada da escola básica e do ensino médio, deixando-o opcional para que os próprios Conselhos Estaduais decidissem sobre o ensino da língua. Ao mesmo tempo, o inglês experimentou uma popularidade crescente no país, devido à influência cultural e econômica crescente dos Estados Unidos e ao desejo de que mais e mais brasileiros queriam aprender essa língua. Assim, ambas as LDBs, a primeira de 1961 (BRASIL 1, 2015) e a segunda, de 1971 (BRASIL 2, 2015), negligenciaram o ensino da língua inglesa, assim como outras línguas estrangeiras e, dessa forma, contribuiram para o retrocesso do desenvolvimento do ensino no contexto histórico do Brasil (HELB 2, 2015).

Outro aspecto importante nessa década de1960 foi a afluência de mais e mais pessoas do campo para as cidades que cresciam rapidamente e as crianças que eram de segmentos sociais que estavam, até então, excluídas da educação escolar precisavam de acesso às escolas. Dessa forma, a demanda de professores nas escolas básicas também aumentou significativamente (PIMENTA, 2005).

Já com a segunda LDB, de 1971, o ensino básico se reestruturou na época e tinha como lema "educação para todos". Um fato importante de se observar é que o Brasil teve de enfrentar uma duplicação do número de alunos entre 1960 e 1990 que, por sua vez, teve como efeito a carência de professores para cobrir as necessidades. Isso levou ao surgimento de muitas faculdades particulares em todo o país que passaram a oferecer cursos de Licenciatura em apenas 3 anos (SILVA, 2013).

No que diz respeito à formação profissional de professores de inglês no Brasil, Monteiro (2011) descreve duas fases distintas pelas quais esses professores passaram: a primeira, a partir do final dos anos 70 que durou até o início dos anos 80; e a segunda, a partir de meados da década de 80 que durou até o final da década de 90.

Ainda, segundo o autor, durante a primeira fase, a Licenciatura foi, na maioria dos casos, estritamente dividida em "disciplinas de conteúdo" (3 anos), seguido pelas disciplinas da "formação pedagógica" (1 ano), conhecido como "Modelo 3+1". Esse modelo foi alvo de 
fortes críticas dos professores da área pedagógica que interpretaram e questionaram essa separação como um preconceito evidente contra à formação pedagógica da Licenciatura: a disciplina "Prática de Ensino" foi inserida no Departamento de Educação, e, portanto, não acessível aos professores do Departamento de Letras que dominavam o idioma inglês.

Ainda, segundo o autor, essa primeira parte da formação profissional do professor de línguas foi seguida pelo ensino dos principais pressupostos teóricos da área de ensino de línguas estrangeiras, bem como os pressupostos psicológicos e pedagógicos das abordagens tradicional (gramática/tradução) e estrutural (abordagem estrutural), que refletem os conceitos subjacentes do tempo. Por fim, o autor relata que os estágios foram realizados principalmente no ensino da rede pública, devido ao fato de que a instituição tinha, naquele tempo, problemas significativos e uma grande demanda por soluções. As atividades que eram efetuadas no decurso do estágio consistiam, principalmente, na observação e participação das aulas que eram conduzidas pelo próprio professor da classe.

A segunda fase da formação de professores de línguas, a partir de meados dos anos 80, é descrita por Monteiro (2011) como período de transição para o modelo comunicativo.

Celani (1984, p.74), por sua vez, entende que:

[...] os nossos cursos de Prática de Ensino tenham como objetivo primordial não apenas informar o futuro professor sobre teorias e abordagens para o ensino de inglês e adestrá-lo no uso de técnicas e equipamentos mais ou menos sofisticados, em sala de aula, mais sim, e, antes de mais nada, capacitá-lo a avaliar essas teorias, abordagens e técnicas criticamente, face a realidade educacional em que irá atuar. $\mathrm{O}$ contato direto com essa realidade deverá ser feito nos estágios de observação e nos de regência, quando estes forem possíveis.

Segundo a autora, um dos principais problemas dessa fase de transição foi que os livros didáticos ainda eram baseados na abordagem estrutural, deixando quase nenhum espaço para a aplicação das ideias que a nova abordagem comunicativa exigia, ou seja, o foco no uso real da língua-alvo. Isso também foi agravado pelo fato de que muitos professores não dominavam suficientemente o idioma inglês, consequentemente, permanecendo despreparados e inseguros para o desafio de ensinar o inglês comunicacional (CELANI, 1984). As mudanças em relação à formação de docentes na década de 1980 baseiam-se, segundo Gimenez e Mateus (2009, p.115-116), em um novo pensamento que surgiu naquele tempo:

No quadro de uma sociedade capitalista globalizada na qual a categoria trabalho, em geral, e trabalho do professor, em específico, é substituida pelas categorias de prática, ganham destaque as investigações fenomenológicas que buscam iluminar a 
atividade humana mais do que descobrir padrões generalizáveis que a governam. Desse modo, a década de 80 protagonizou transformações mediadas por estudos na área do pensamento do professor com especial interesse sobre o que os professores sabem e como adquirem tais conhecimentos.

Em contraste com o paradigma positivista dos anos 1960/70, a prática de ensino nos anos 1980 passou a ser considerada como algo que acontecia de forma intuitiva, baseada e desenvolvida em sala de aula (FREITAS, 2003). Schön (1987, p.13) fala sobre os professores desse último período como "profissionais de destaque" caraterizados por terem "mais 'sabedoria', 'talento', 'intuição' e artistry (talento artístico)”.

Contudo, de acordo com Sturm (2011), foi apenas na década de 1990 que as pesquisas em relação à formação de professores de inglês no Brasil intensificaram-se, refletidas nas polêmicas, discussões e questionamentos veiculados pelas obras de vários autores (ALMEIDA FILHO, 1993,1999; MOITA LOPES, 1996; VIEIRA-ABRAHÃO, 1992, 1996, 1999; PAIVA, 1996, 1997). O ensino de inglês recebeu uma maior valorização, em 1996, com a promulgação da terceira LDB, que determinou a obrigatoriedade do inglês no ensino fundamental. A partir da $5^{\mathrm{a}}$ série, colocou-se, assim, nos currículos uma $\mathrm{LE}^{2}$ moderna obrigatória que podia ser escolhida pela própria instituição e uma segunda LE optativa, de acordo com as possibilidades da escola (HELB 3, 2015).

Dessa forma, é possível perceber, por meio da história, que o ensino de línguas estrangeiras no Brasil, inclusive o ensino de língua inglesa, objeto da pesquisa aqui relatada, teve muitos percalços com o estabelecimento de uma política pública que valorizasse tanto a formação do profissional de línguas quanto sua obrigatoriedade de ensino de línguas estrangeiras nas escolas. Portanto, apenas a partir da década de 90, ou seja, pouco tempo depois que a situação do ensino de línguas teve mais atenção como política pública, os pesquisadores passam a ter um olhar mais apurado quanto à formação inicial desse docente (TEDESCO; FANFANI, 2004).

Depois de resumir a história da formação de professores de línguas no Brasil, apresento a seguir um relato sobre a situação atual.

\footnotetext{
${ }^{2}$ Língua Estrangeira (doravante LE)
} 


\subsubsection{A situação atual}

Antes de discutir a situação da formacão inicial de professores de LE no Brasil, é necessário, a meu ver, realçar que características fazem um bom professor de LE, indicando inclusive as competências a serem adquiridas durante a formação inicial.

Em 1992, Vieira-Abrahão considerou certas caraterísticas essenciais para um professor de LE bem formado, das quais se destacam as seguintes:

1) a competência comunicativa na língua alvo;

2) ter consciência e crítica de sua prática;

3) ser consciente da sua função de educador, constantemente questionando os cursos de Letras e as disciplinas pedagógicas;

4) ser consciente da imprescindibilidade da aprendizagem continuada.

Por outro lado, Almeida Filho (2001, p.20) descreve as caraterísticas de um bom professor de LE da seguinte forma:

[...] são a competência implícita (que se desenvolve em nós a partir das experiências de aprender língua(s) que vivemos), competência teórica (corpo de conhecimentos que podemos enunciar), competência aplicada (o ensino que podemos realizar orientado e explicado pela competência teórica que temos), competência linguisticocomunicativa (a língua que se sabe e se pode usar) e a competência profissional (nosso reconhecimento do valor de ser professor de língua, nossa responsabilidade pelo avanço profissional próprio e dos outros e as ações correspondentes).

Além de todos esses atributos que um professor de língua estrangeira idealmente deveria ter, surge a pergunta sobre quais os objetivos que deveriam ser alcançados com relação à aprendizagem de línguas estrangeiras, oficialmente.

No Brasil, constam dos Parâmetros Curriculares Nacionais ${ }^{3}$ (BRASIL 3, 1998, p.19), que servem como "fonte de referência para discussões e tomada de posição sobre ensinar e aprender Língua Estrangeira nas escolas brasileiras", como objetivos que deveriam ser almejados a restauração do papel da Língua Estrangeira na formação educacional e o direito universal dos cidadãos de aprenderem uma língua estrangeira juntamente com a língua materna. Portanto, o mesmo documento ilustra que a situação real é, de fato, bastante diferente, mostra-se que pouca relevância é dada ao ensino de LE no Brasil:

\footnotetext{
${ }^{3}$ Parâmetros Curriculares Nacionais de Língua Estrangeira, publicados pelo MEC (Ministério de Educação) doravante PCNs.
} 
Deve-se considerar também o fato de que as condições na sala de aula da maioria das escolas brasileiras (carga horária reduzida, classes superlotadas, pouco domínio das habilidades orais por parte da maioria dos professores, material didático reduzido ao giz e livro didático, etc.) podem inviabilizar o ensino das quatro habilidades comunicativas. Assim, o foco na leitura pode ser justificado em termos da função social das LE no país e também em termos dos objetivos realizáveis tendo em vista as condições existentes (BRASIL 3, 1998, p.21).

A partir das assertivas acima, revela-se certa distância entre desejo e realidade, que é causada por uma variedade de razões, inclusive a qualidade da formação dos professores.

No entanto, segundo Celani (2009, p.10), a falta de interesse da parte política no Brasil no que diz respeito ao ensino de línguas estrangeiras leva, consequentemente, a várias deficiências para a formação dos professores que finalmente afetam os alunos diretamente. Durante sua formação inicial os professores são mal preparados para a realidade deles, faltando o conhecimento nos conteúdos, nas disciplinas bem como o saber sobre como conduzir o ensino na sala de aula. A autora considera que:

Esta falha é particularmente visível na área de ensino de línguas, com acentuada força na área de ensino de línguas estrangeiras, na qual conhecer significa também saber usar. As consequências dessa deficiência são particularmente preocupantes, de vez que [...], no caso das línguas-estrangeiras, podem causar distorções insanáveis nas representações dos alunos a respeito do ensinar-aprender uma outra língua.

Portanto, os estudantes, principalmente os das escolas públicas, são excluídos da aprendizagem de uma língua estrangeira. O "mito" de que "língua estrangeira não se aprende na escola", como descrito por Celani (2009, p.10), ainda pode ser percebido muitas vezes quando se aborda o tema. Silva (2013, p.8) confirma isso quando fala sobre a situação atual dos professores de inglês nas escolas públicas do Brasil, constatando que

[...] professores desestimulados ainda ensinam gramática e tradução, de maneira tradicional, a grupos de alunos totalmente desinteressados [...] Muitos fatores subjazem a este estado de coisa: infraestrutura escolar deficiente, na qual é visível a omissão do estado, da direção e da coordenação escolar; alunos apáticos e/ou agressivos; salários baixos; professores mal formados, carentes de programas de educação continuada e desvalorizados socialmente.

Moura Filho (2011, p.49), por exemplo, critica de forma veemente a situação atual da formação dos professores de Letras no Brasil, considerando-a um verdadeiro "círculo vicioso" que, como consequência, torna difícil para os professores de línguas ou até mesmo os impede de enfrentar os desafios com os quais se veem confrontados na vida moderna:

A persistência de condições inadequadas de formação de professores de Letras (MOITA LOPES, 1996, e PAIVA, 2004, inter alios), aliada a projetos pedagógicos conservadores, a inacessibilidade de experiências acadêmicas de ponta, ainda que de forma bibliográfica, aos processos de formação continuada, a desqualificação das habilidades e competências adquiridas fora da instrução formal, a dissociação entre 
teoria e prática e ao forte embasamento na racionalidade técnica, marcado pela valorização de técnicas de ensino e pela restrita participação dos alunos na construção de conhecimento, formam um verdadeiro círculo vicioso, que impede, ou no mínimo dificulta, uma qualificação de professores de línguas identificada com as reais demandas da sociedade, que os transforme em protagonistas de suas práticas profissionais e que os reencantem com seus papéis.

Segundo Paiva (2004), os problemas na formação de professores de inglês no Brasil são causados pela falta de conteúdos significativos em cursos de Letras, como pode ser visto em muitas instituições de Ensino Superior: conteúdos de formação de professor de LE são, geralmente, ignorados e é raro o curso que oferece atividades curriculares que estimulem reflexões sobre a aquisição, o ensino e aprendizagem de LE. A mesma autora (2006, p.64) também constata que "os espaços reservados nos projetos pedagógicos para a formação de professor de língua estrangeira e os conteúdos selecionados são insuficientes para uma boa formação do futuro professor de inglês".

Vieira Abrahão (2009) indica como deficiências de cursos para a formação de professores de línguas a falta de projetos de pesquisa, especialmente aqueles direcionadas para a reflexão e prática do professor de LE nas escolas públicas brasileiras, e a ausência de projetos de médio e longo prazo para esses professores, oferecidos pelas universidades brasileiras. No entanto, Silva (2013, p.12) comenta sobre a situação problemática contínua da formação de professores no Brasil, respectivamente os cursos de licenciatura:

[...] o MEC permanece aprovando cursos que formam professores sem preparo suficiente para exercer a docência. Infelizmente, nada mudou, o modelo datado de 30 anos atrás ofertando cursos de licenciaturas duplas, com currículos e bibliografias desatualizados, cujos propósitos incoerentes apresentam desconexão entre os objetivos do curso e o perfil de licenciando a ser formado.

Dutra e Mello (2004, p.37) também indicam os problemas provenientes de uma formação inicial rápida que, segundo os autores, não permite espaço suficiente para uma boa prepararação dos futuros professores:

Muitos desses cursos são ministrados em três anos e recebem alunos de escolas de ensino básico que também não investiram em um ensino de LE de qualidade. A maioria dos projetos pedagógicos que passam pela SESu, seja para autorização ou reconhecimento, devota ao ensino de inglês ou espanhol, cerca de 360 horas, ou no máximo 480 horas de ensino de língua estrangeira como acréscimo de 60 a 120 horas de literatura inglesa e norte-americana. A parte de formação de professor de língua estrangeira é praticamente inexistente e em muitos casos é de competência de departamentos de educação onde pedagogos não têm a formação específica na área de ensino de LE. As aulas de literatura são dadas geralmente em português e as turmas chegam a ter 50, 70 e até 90 alunos, inviabilizando a oferta de um ambiente adequado à prática de idioma. Como resultado, o sistema educacional brasileiro coloca no mercado de trabalho professores despreparados e muitos recorrem aos cursos de especialização em busca de uma regraduação, o que naturalmente não 
encontram. Esse contexto reforça, dia a dia, o preconceito de que só se aprende língua estrangeira em cursos livres.

Paiva (2004) ao referir-se ao já extinto Exame Nacional de Cursos (dito provão), aponta que a formação de professores de LE ainda estava negligenciada, seus conteúdos geralmente não ganhavam a atenção necessária, e quase não existiam cursos que promoviam a reflexão sobre a aquisição, a aprendizagem e o ensino de uma LE.

Celani (2003, p.20) analisa a situação atual do ensino de inglês no Brasil da seguinte forma:

O ensino de língua estrangeira, particularmente do inglês, encontra-se totalmente à
deriva, com professores, pais e alunos muitas vezes se perguntado a mesma coisa: O
que estamos fazendo aqui? Para que servirá esta tentativa frustrada de se
ensinar/aprender outra língua?

Segundo Barcelos (2011, p.150) essa situação é uma das razões para a opinião amplamente difundida de que as escolas públicas não são o lugar onde uma língua estrangeira pode ser aprendida, como ele constata: "trata-se de uma crença perniciosa, que fomenta práticas sociais que negam o direito à aprendizagem de línguas estrangeiras garantido a todo cidadão brasileiro pela Constituição Federal”.

A falta de competência do professor, que já foi mencionado acima, consequentemente leva a outro problema, descrito por Freire (2007, p.91): “a segurança com que a autoridade docente se move implica uma outra, a que se funda na sua competência profissional. Nenhuma autoridade docente se exerce ausente desta competência”.

Por isso, é necessário pensar em como criar uma melhor formação inicial de professores, com conteúdos relevantes no tocante à prática e aos desafios que o professor encontra, com conteúdos que conectem as partes teórica e prática e fornecam as ferramentas necessárias que permitam a ele começar sua carreira profissional bem preparado, com uma atitude positiva e com autoconfiança.

Barcelos, já em 1995, oferece algumas respostas possíveis para melhorar a formação de LE e os cursos de Letras, propondo uma reformulação do currículo envolvendo uma extensão da Prática de Ensino da língua-alvo, considerando o tempo real que se dedica a ela, que é um semestre, como muito curto. Ela também defende a inclusão de mais disciplinas específicas da Linguística Aplicada, como, por exemplo, o ensino e a aprendizagem de uma segunda língua/língua estrangeira como uma medida significativa para completar o Curso de Letras. 
Assim sendo, vários esforços foram introduzidos a fim de melhorar os Cursos de Letras, dos quais alguns serão apresentados a seguir. A Resolução $\mathrm{n}^{-} 2$ do $\mathrm{CNE}^{4}$ (de 09/12/2002, em vigor em 2005) determina o aumento das horas dedicadas ao estágio supervisionado para 400, a fim de atender às postulações de muitos formadores de professores para colocar um foco maior sobre a experiência prática dos futuros docentes (SILVA, 2013).

Outra medida realizada pela CAPES (Coordenação de Aperfeiçoamento de Pessoal de Nível Superior) consiste em fornecer bolsas, por meio do PIBID (Programa Institucional de Bolsa de Iniciação à Docência), para licenciandos que participam de projetos que foram iniciados pela IES, em colaboração com escolas de educação básica da rede pública de ensino. Os participantes desenvolvem, sob a orientação de professores da Licenciatura bem como da escola, programas e atividades didático-pedagógicas. O programa existe apenas desde 2009 (SILVA, 2013). Também, nos últimos anos, diversas instituições brasileiras têm se dirigido para o desenvolvimento de projetos tendo como objetivo melhorar a qualidade do ensino de inglês no setor público, no Brasil, como aponta Gimenez (2009).

A ANPOLL ${ }^{5}$, por exemplo, tem gerado alguns trabalhos de ordem política: seu subgrupo de pesquisa Formação de Professores, do grupo de pesquisa Linguística Aplicada como parte integrante dessa Associação, publicou, em 2009, um livro com o nome de "Formação Inicial e Continuada de Professores de Línguas: dimensões e ações na pesquisa e na prática”. O livro, ao ilustrar pesquisas conduzidas em várias regiões e contextos do país, trata de vários assuntos como o desenvolvimento continuado de professores por meio de recursos tecnológicos, das políticas públicas e da reflexão sobre a prática docente, só para citar alguns, refletindo a crescente importância dessa área no Brasil inteiro (CELANI, 2009).

Por fim, seria de suma importância mencionar Cardoso (2002, p.215), que recapitula vários pontos fundamentais para a desmotivação dos professores. No entanto, sua crítica, além de abordar todos os outros fatores apresentados por outros autores, também aponta a responsabilidade do próprio professor como ponto crucial para o processo de melhoria das questões relacionadas à profissão:

Toda essa falta de motivação pode ser explicada pelas várias dificuldades constantes na profissão docente no Brasil, principalmente na escola pública, como: a

\footnotetext{
${ }^{4}$ Conselho Nacional de Educação

5 A Associação Nacional de Pós-Graduação e Pesquisa em Letras e Linguistica, fundada em 1984, é uma organização brasileira de âmbito nacional que já realizou 28 chamados para Encontros Nacionais, com as reuniões centradas na política brasileira de Pós-Graduação, e também realiza debates no que diz respeito ao trabalho de os chamados GTs (Grupos de Trabalho) temáticos. Site no link - http://anpoll.org.br
} 
desvalorização financeira do professor, a falta de respeito aos profissionais do ensino, a falta de condições materiais e físicas para trabalhar, a falta de um plano de carreira, a presença de uma ideologia educacional não condizente com a necessidade popular, etc. Mas, nenhum desses problemas pode justificar a incompetência ou a irresponsibilidade de um professor que não quer se envolver com a educação [...]

Essa responsabilidade descrita por Cardoso (2002) para os professores tomarem iniciativas a fim de contribuirem para resolver esses problemas parece mesmo uma necessidade. Contudo, considerando o grande número de fatores descritos anteriormente que contribuem para a situação atual da formação de professores no Brasil, levanta-se, então, a pergunta: o que um professor individual pode fazer a fim de resolver certos problemas e melhorar sua própria situação profissional?

Sabota (2010, p.154) aponta a necessidade de utilizar uma reflexão constante já durante a formação inicial de professores, também apontando a necessidade para os professores de, autonomamente, procurarem respostas para as perguntas que surgem durante essa formação:

Para que os professores em formação sintam-se habilmente preparados para a docência, é preciso que os professores formadores incentivem o estudo e o aprimoramento constante desses profissionais, e, sobretudo, a autonomia na busca de opções que se adequem ao seu estilo de ensinar, à destreza no manejo das peculiaridades da sala de aula (como: gerenciamento de classe, disciplina, organização e planejamento de curso, entre outros) e à reflexão.

Essa necessidade de usar a reflexão como ferramenta que permite aos futuros professores se prepararem para os desafios que irão enfrentar na sua vida profissional também é enfatizada por Perrenoud (2002, p.104):

A formação de "profissionais reflexivos" deve se tornar um objetivo explícito e prioritário em um currículo de formação dos professores; em vez de ser apenas a familiarização com a futura prática, a experiência poderia, desde a formação inicial, assumir a forma simultânea de uma prática "real" e "reflexiva".

Depois de contemplar a formação inicial de professores no Brasil e suas implicações, serão explorados mais detalhadamente, na seção seguinte, os diferentes aspectos do conceito de "professor reflexivo" mencionado anteriormente, a fim de ver quais possibilidades oferece para ajudar os professores em formação, no nosso contexto. 


\subsubsection{O professor reflexivo}

Os estudos do filósofo pragmático norte-americano ${ }^{6}$ Dewey (1859-1952) são considerados os primeiros a apontar a relevância da ação reflexiva na educação. Ele estava muito preocupado com a educação de seu tempo, marcado pela tradição, autoridade, obediência e submissão, como descrito por Geraldi, Messias e Guerra (1998).

As ideias de Dewey (1958, apud MOURA FILHO, 2011, p.51-52), a propósito da "prática reflexiva", que surgiram dessa preocupação foram traduzidas em sugestões que refletem, especificamente, a importância da experiência que um professor deve ter a fim de efetuar um ensino reflexivo:

1) as perguntas que são contempladas pelos professores precisam ocorrer no contexto social do ensino;

2) um interesse natural do professor de resolver o problema é essencial;

3) as questões que afetam o professor precisam se originar a partir de sua prática pessoal;

4) a reflexão visa, finalmente, chegar a uma solução do problema;

5) espera-se do próprio professor que seja capaz de identificar e resolver as questões;

6) a intervenção tem que ser baseada em uma abordagem estruturada;

7) os problemas que estão sujeitos a observação se originam da própria experiência do professor na sala de aula;

8) o próprio professor precisa testar suas ideias sobre o ensino na sala de aula;

9) estes testes exigem determinadas ações que, por sua vez, mostram a discrepância natural que existe entre si mesmos e a ideia;

10) as ações reflexivas, consequentemente, geram um novo conhecimento que, finalmente, redefine uma aplicação do ensino.

Foi Zeichner (1993) quem primeiro caracterizou o conceito do "professor reflexivo", descrevendo um educador que usa a reflexão na sua vida profissional a fim de melhorar a qualidade de seu ensino. Porém, segundo Pimenta (2005), o termo "profissional reflexivo"

\footnotetext{
${ }^{6}$ PRAGMATISMO: Escola filosófica que defendia a origem empírica do conhecimento que pode ser alcancado por meio da experiência. Esta experiência é resultado de uma interação contínua entre as pessoas e seu ambiente e, portanto, reflete os sujeitos bem como os objetos em questão.
} 
remonta ao livro O Profissional Reflexivo de Donald Schön, publicado em 1983, e, portanto, ele pode ser considerado como principal formulador desse conceito.

Contudo, esse conceito começou a ser ouvido no mundo falante de português com a publicação do livro Os Professores e sua Formação, de 1992, do autor português António Nóvoa, e com o primeiro "Congresso sobre Formação de Professores nos Países de Língua e Expressão Portuguesa", realizada em Aveiro, Portugal, sob a coordenação de Isabel Alarcão, em 1993 (SOUZA; LOPES, 2012).

O forte impacto desse livro no Brasil, que consiste em uma coletânea de artigos de diferentes autores sobre o tema da formação reflexiva, é descrito por Geraldi, Messias e Guerra (1998, p.239):

Eram tantos textos e autores interessantes nesta obra, a começar pelo próprio organizador, que, mais que um conjunto de autores, nele apresenta-se uma nova forma de pensar/compreender o professor e a professora, bem como sua formação. Para nós, foi particularmente significativo por fortalecer e confirmar muitos dos argumentos e teses que há muitos anos defendíamos e vivíamos no Brasil.

Além disso, existem vários conceitos que tratam do professor reflexivo:

Silva (2005) considera a reflexão do professor um meio eficaz para teorizar a sua prática, a fim de expandir o seu conhecimento profissional, para efetuar mudanças e agir de forma autônoma. No entanto, ela não restringe esse conceito puramente à construção de conhecimento ao professor na escola, ela o vê também em um contexto político, como uma ferramenta dirigida contra o capitalismo e o poder, servindo para alterar a sociedade e superar a injustiça social, especialmente nos países pobres.

Para Kemmis (1986, apud BARTLETT, 1990, p.204), a reflexão

[...] não é apenas um processo individual e psicológico. É um quadro social e político, orientado para uma ação e historicamente incorporado, para se localizar no contexto histórico de uma situação, para participar em uma atividade social, e, também, para tomar partido nas questões. Além do mais, o material no qual a reflexão se aplica nos é dado socialmente e historicamente; por meio da reflexão que a ação informa, podemos transformar as relações sociais que caracterizam a nossa profissão e nossa situação de trabalho. ${ }^{7}$

Bartlett (1990) usa a expressão critical reflective teacher (professor crítico reflexivo), explicando que os professores devem considerar as suas ações em seu contexto histórico,

\footnotetext{
${ }^{7}$ do original: [...] is not just an individual, psychological process. It is an action oriented, historically-embedded, social and political frame, to locate oneself in the history of a situation, to participate in a social activity, and to take sides on issues. Moreover the material on which reflection works is given to us socially and historically; through reflection and the action which it informs, we may transform the social relations which characterise our work and our working situation.
} 
social e cultural o que, consequentemente, permite-lhes evoluir individual e coletivamente. A fim de efetuar essa reflexão crítica, ele sugere que os professores façam várias perguntas para si mesmos, das quais selecionei aquelas que interessam aos propósitos da pesquisa aqui relatada:

1) o que é relevante como conhecimento na aprendizagem de uma segunda língua?;

2) o que me levou a tornar-me um professor de segunda língua?;

3) estes motivos ainda existem para mim?;

4) quem tem o poder na minha sala de aula e como ele é expresso?;

5) como eu poderia ensinar de maneira diferente?;

6) como posso, pessoalmente, trabalhar para descobrir as contradições do meu ensino?;

7) como o que eu faço pode influenciar as oportunidades na vida dos meus alunos?;

8) quero revelar o "currículo oculto" - as inconsistências - da minha prática?.

A proposta de Schön (1992), com base nos estudos de Dewey, consistiu na aplicação da análise, problematização e reflexão da prática existente do professor. Para ele, são essas as medidas que devem viabilizar novas descobertas. No entanto, essa proposta foi fortemente criticada por Pimenta (2005, p.20), que não a considera adequada para cumprir o seu próprio entendimento de reflexão: "Frente a situações novas que extrapolam a rotina, os profissionais criam, constroem novas soluções, novos caminhos, o que se dá por um processo de reflexão na ação".

Nas questões de Schön (ibid.) mencionadas acima, reflete-se um processo cíclico de atividade na continuação desse questionamento. As ideias originais de Dewey refletidas neste ciclo foram base para vários conceitos de processos de investigação. Como é o caso de Bartlett (1990), que redefine esse processo cíclico, constatando que cada elemento do ciclo é reflexivo em si mesmo e, dependendo da ação que é realizada, nem todos os elementos necessariamente precisam ser aplicados. No entanto, cada elemento é guiado por questionamentos:

1) mapeamento: O que eu faço como professor?;

2) informação: Qual é o significado do meu ensino?;

3) discussão: Como me tornei assim?;

4) avaliação: Como eu poderia ensinar de forma diferente?; 
5) ação: O que e como devo ensinar agora?. ${ }^{8}$

Dewey caracterizou os dois conceitos de "ato de rotina" e "ato de reflexão", com base em seus pressupostos. De acordo com Moura Filho (2011, p.52),

\begin{abstract}
o ato de rotina é dirigido pelo impulso, pelos valores tradicionais vigentes e pela voz da autoridade. São filiados a essa orientação pessoas que acatam, sem questionamentos e de forma natural, as relações sociais nas quais estão inseridas, sem pensar em trabalhar por implantação de melhorias pessoais e coletivas. $\mathrm{O}$ "ato de reflexao", por sua vez, não é automatico, envolve emoção, intuição e paixão e é identificável em pessoas que buscam empenhar os melhores de seus talentos para a promoção de mudanças.
\end{abstract}

Foi na década de 1980 que as primeiras propostas com relação a uma formação reflexiva de professores surgiram (MOURA FILHO, 2011). Uma das principais razões pela qual essas propostas encontraram atenção é baseada na crise do sistema educacional naquele momento e que se originou, principalmente, na desconfiança do conhecimento profissional dos docentes o que, portanto, desencadeou uma "busca de uma nova epistemologia da prática profissional" (SCHÖN, 1992, p.80).

Schön foi o primeiro a apresentar uma alternativa ao modelo de formação do professor que tinha sido predominante até então e que foi baseado numa racionalidade técnica, seguindo as três etapas de expor o professor à teoria, à aplicação dessa teoria e, finalmente, à condução do estágio. Ele encampou muitas das noções de Dewey, aprimorandoas em seus livros, entre eles The Reflective Practicioner (O Profissional Reflexivo, 1983), que foi o ponto inicial para o desenvolvimento de uma nova maneira de se formar os docentes (MOURA FILHO, 2011).

Em seu livro, Educating the Reflective Practicioner (Formação de Profissionais Reflexivos, 1987), Schön apresenta um modelo que contém três etapas de reflexão consideradas por ele cruciais para efetuar o crescimento do pensamento prático dos professores. Ele descreve esse modelo da seguinte forma:

1) reflexão-na-ação: o professor reflete sobre uma ação espontaneamente, no momento em que está acontecendo;

2) reflexão sobre a ação: o professor reflete sobre o que deu errado, em busca de reenunciar suas práticas;

\footnotetext{
${ }^{8}$ do original: 1. mapping: what do I do as a teacher?; 2. informing: what is the meaning of my teaching?; 3 . contesting: how did I come to be this way?; 4. appraisal: how might I teach differently?; 5. acting: what and how should I teach now?
} 
3) reflexão sobre a reflexão na ação: supõe-se que esta última fase ajude o professor a obter novos conhecimentos, proativamente ajudando-o a entender novos problemas e encontrar recursos para ações futuras.

Schön, assim, valoriza a prática na formação dos profissionais, "mas uma prática refletida, que lhes possibilite responder as situações novas, nas situações de incerteza e indefinição", como aponta Pimenta (2005, p.20).

Apesar dos muitos aspectos positivos dessa reflexão, baseada nas ideias originais de Schön, Pimenta (2005, p.44) indica alguns problemas desse conceito: “[...] o individualismo da reflexão, a ausência de critérios externos potenciadores de uma reflexão crítica, a excessiva (e mesmo exclusiva) ênfase nas práticas, a inviabilidade da investigação nos espaços escolares e a restrição desta nesse contexto". O autor também justifica a imprescindibilidade de substituir o antigo modelo mencionado acima, destacando que:

[...] o profissional assim formado, conforme a análise de Schön, não consegue dar respostas às situações que emergem no dia-a-dia profissional, porque estas ultrapassam os conhecimentos elaborados pela ciência e as respostas técnicas que esta poderia oferecer ainda não estão formuladas (PIMENTA, 2005, p.19).

Mok (1994), por sua vez, afirma que a reflexão consiste em uma ação e a cogitação crítica sobre ela, observando-se permanentemente o desenvolvimento de uma medida, o que sublinha o carácter cíclico desse processo. Este procedimento, segundo Mok, permite que um professor tire conclusões sobre si mesmo. Ele chama essas conclusões de insights, que podem, possivelmente, efetuar mudanças fundamentais em como um professor se percebe na sua função.

Freitas (2009, p.51) destaca a necessidade da reflexão do professor para seu próprio ensino. Segundo ela, o termo "consciência" alcançou uma grande importância no contexto da formação de professores de LE nos anos 90. Ela até considera essa "consciência" um passo indispensável que inicia a autorreflexão de um professor:

Refletir sobre o próprio ensino, por sua vez, é a condição que leva o professor de LE a assumir um status profissional, deixando de ser visto como um mero operário a desempenhar seu ofício, seguindo caminhos ou direções que lhe são indicados ou repetindo fórmulas que lhe são prescritas por especialistas que estariam legitimamente autorizados a assim proceder, pois deles seria o saber resultante do pensar.

De acordo com Cavalcanti (1990), essa conscientização resultante de leituras e discussões promove a flexibilidade do professor e a habilidade para improvisar, na sala de 
aula. Fonseca (2009, p.91) também enfatiza a importância dessa conscientização para professores, mostrando os benefícios, bem como suas limitações:

A conscientização do professor vai permitir que ele conheça suas crenças, seus mitos, pressupostos culturais e ideias sobre como ensinar e aprender línguas, permitindo que se torne mais crítico na tarefa a que se propôs. Dúvidas, incertezas e questionamentos continuam a existir. Entretanto, a tomada de consciência possibilita uma maior discussão e possível entendimento dos fatos e consequentemente o início de tentativas de modificação de alguns aspectos ligados à prática em sala de aula.

Freeman (1989) traz um aspecto interessante sobre essa tomada de consciência no nosso contexto de reflexão, afirmando que esse mesmo processo sobre como se age na prática pedagógica já representa, subconscientemente, um dos aspectos da mudança, sem o professor necessariamente desejar alterar suas ações.

Freitas (1996) apoiado em Almeida Filho (1995), menciona que os professores realmente motivados não necessariamente precisam aplicar uma profunda sistematização a fim de refletir sobre as suas práticas de ensino, eles alcançam essa reflexão desejada por meio do partilhar de experiências com os colegas mais experientes ou pela participação em eventos.

De acordo com Almeida Filho (1995), os professores devem ter a oportunidade de refletir sobre si mesmos antes de compartilharem suas experiências com um supervisor, outro colega ou um pesquisador nesta área. Apesar disso, é essencial para o professor, depois dessa primeira autorreflexão inicial, compartilhar essas experiências com outra pessoa a fim de consolidar ideias refletidas e, finalmente, avançar profissionalmente.

Segundo Romero (2004), os professores em formação deveriam usar a autorreflexão e se concentrar em suas próprias atividades durante esse tempo, a fim de analisá-las e melhorálas. Sabota (2008) também recomenda a troca de experiências e ideias com outros colegas, a fim de alcançar novos conhecimentos e, finalmente, tornarem-se os professores que idealmente gostariam de ser. Dada a situação da formação de professores do Brasil descrita anteriormente, alguns autores brasileiros têm abordado as suas preocupações e, ao mesmo tempo, apontaram a importância da reflexão.

Para os professores que estão dispostos a refletir sobre sua prática, Almeida Filho (2005, apud MOURA FILHO, 2011, p.57-58), recomenda diferentes temas que orientam o processo de reflexão e poderão ser objeto de uma autoavaliação:

1) buscar sentidos globais do próprio ensino (em pormenores);

2) pautar-se por critérios próprios;

3) estabelecer juízos de coerência entre o que diz fazer e o que de fato faz; 
4) buscar dados e evidências nas gravações e transcrições de aulas (típicas);

5) buscar explicações para os procedimentos e conteúdos de suas aulas;

6) assumir a subjetividade do ato de avaliar interpretando e tomando providências para minimizar efeitos indesejados;

7) buscar rigor na amostragem, na triangulação de evidências e na completude das observações (gravações, notas de campo, diários);

8) buscar compreensões novas e crescentes acerca da complexidade dos processos de ensinar e aprender línguas na escola (teoria apropriada).

Para que um professor seja capaz de agir e iniciar o processo de reflexão, ele deve, idealmente, ser apoiado pela instituição em que está trabalhando, segundo Alarcão (2004, p.44):

O professor não pode agir isoladamente na sua escola. É neste local, o seu local de trabalho, que ele com os outros, seus colegas, constrói a profissionalidade docente. Mas se a vida dos professores tem o seu contexto próprio, a escola, de ser organizado de modo a criar condições de reflexividade individuais e coletivas. Vou mais longe. A escola tem de se pensar a si própria, na sua missão e no modo como se organiza para a cumprir. Tem, também ela, de ser reflexiva.

De todas as características que Alarcão (2004) lista ao descrever as condições necessárias que uma instituição disposta a integrar reflexão deve prestar, considero os seguintes pontos os mais importantes, como descrito por Moura Filho (2011, p.58):

1) ser capaz de liderar e mobilizar as pessoas;

2) assegurar uma atuação sistêmica;

3) assegurar a participação democrática;

4) pensar e escutar antes de decidir;

5) ser consequente;

6) acreditar que todos e a própria escola se encontram num processo de desenvolvimento e de aprendizagem.

Blatyta (2009, p.78) exige claramente do professor a postura de "lutar contra a falta de reflexão e contra respostas automáticas, únicas, autoritárias, buscadas quase sempre fora dele mesmo, e não dentro de suas experiências pessoais." Ela sugere algumas medidas a fim de promover a criação de uma ação reflexiva em sala de aula: dedicar algum tempo ao final de cada aula, a fim de anotar reflexões sobre o decurso dela bem como novas ideias que possam ter surgido. A discussão e a transferência dessas reflexões poderiam, por sua vez, promover reuniões pedagógicas e, possivelmente, contribuir para influenciar positivamente o ambiente na instituição. No entanto, a autora enfatiza que as mudanças só podem ser alcançadas por meio da reflexão constante e contínua, com base em uma visão crítica que, por sua vez, 
resulta de os professores serem confrontados com soluções alternativas, contradições e até mesmo conflitos causados pelas visões dos outros.

Cavalcanti e Moita Lopes (1991) demandam a reflexão dos professores sobre a sua prática em sala de aula e, consequentemente, à execução prática de pesquisa, tanto para a formação inicial quanto para a continuada de professores, a fim de promover o aprimoramento profissional. Foi Prabhu (1990) quem cunhou o termo "senso de plausibilidade", o que significa que os professores deveriam combinar conhecimentos antigos com os novos, a fim de criar novas perspectivas e mudar sua maneira adequada de pensar a fim de gerar verdadeiras mudanças que vêm de dentro.

Outro termo que é importante no nosso contexto e que foi originalmente cunhado por Almeida Filho (1993) é o termo “desestrangeirizar". Esse termo descreve o processo que aprendentes de uma LE desenvolvem na interlíngua e que lhes permite se familiarizar com a língua estrangeira que eles adquirem. Blatyta (2009) usa esse termo no presente contexto da reflexão dos professores, explicando que um professor precisa "desestrangeirizar" as teorias de suas leituras num processo que ela chama de "conscientização teórica", que consiste em experimentar novas técnicas e abordagens que, finalmente, resultam no desenvolvimento dessa consciência.

Pessoa (2011) mostra três aspectos importantes que surgiram como resultado da reflexão colaborativa sobre a prática pedagógica e textos teóricos: os professores que participaram de atividades colaborativas sentiram que eles não estão sozinhos, eles percebiam serem capazes de produzir conhecimento, e eles também foram capazes de mudar as suas práticas, consequentemente considerando esse processo como forma produtiva para a formação profissional de professores de línguas estrangeiras.

É fácil falar sobre possibilidades de como os professores podem ser reflexivos, a fim de melhorar as suas práticas de ensino. No entanto, a realidade dos professores, como o tempo limitado e os poucos recursos financeiros disponíveis a fim de participar de eventos e cursos, e para comprar literatura específica, muitas vezes impedem essas tentativas, tal qual descreve Freitas (2009).

Felix (2009) confirma os pontos acima mencionados, acrescentando que muitos professores também têm que lidar com uma grande carga de trabalho em sua vida profissional. A autora culpa, além disso, a falta de informação sobre a educação continuada e 
também o fato de que muitos professores simplesmente não reconhecem a sua importância, o que, em troca, ela explica com a falta de motivação atribuída à universidade como instituição formadora.

Blatyta (2009) indica outros problemas que podem, eventualmente, impedir esse processo de pesquisa, causado tanto pelas instituições quanto pelos próprios professores, os quais podem aparecer quando se trata da realização do processo de investigação bem como na implementação de mudanças, seja nos currículos ou na adoção de determinados procedimentos. Pimenta (2005, p.20), por sua vez, enfatiza a relevância da integração do conceito da reflexão como componente que constitui o processo da formação integral de professores, desde o início:

Portanto, os currículos de formação de profissionais deveriam propiciar o
desenvolvimento da capacidade de refletir. Para isso, tomar a prática existente (de
outros profissionais e dos próprios professores) é um bom caminho a ser percorrido
desde o início da formação, e não apenas no final, como tem ocorrido com o estágio.

Barth (1990) descreve três tipos diferentes de professores:

1) aquele que não quer olhar para si mesmo de forma crítica nem gostaria que outros o fizessem;

2) aquele que olha para si mesmo de forma crítica, mas não quer que mais ninguém o faça;

3) o professor eminente que esteja disposto a olhar para si mesmo de forma crítica e, ao mesmo tempo, solicita de seus colegas sugestões.

A situação ideal, de acordo com Barth, seria a de levar todos os professores para esse último nível. Nesse sentido, estou de acordo com Dutra e Mello (2004) quando afirmam que a verdadeira reflexão só pode surgir na vida prática de um professor se ele for considerado um profissional que se desenvolve permanentemente e faz isso por iniciativa própria. Também concordo com Freire (2007, p.22) quando ele afirma que "a reflexão crítica sobre a prática se torna uma exigência da relação Teoria/Prática sem a qual a teoria pode ir virando blablablá e a prática, ativismo".

Depois de contemplar vários aspectos relativos ao professor reflexivo, apresento, agora, um olhar mais próximo sobre que papel esse conceito poderia assumir em nosso contexto de formação de professores, mais precisamente em nosso contexto de formação continuada de professores, no Brasil. 


\subsection{A Formação Continuada de Professores no Brasil}

Tedesco e Fanfani (2004) relatam que foram as mudanças sociais e uma crise escolar em todo o mundo que, a partir do final do século XX, provocaram uma discussão sobre o profissionalismo dos professores que, por sua vez, resultaram nas primeiras proposições de uma formação continuada. No Brasil, segundo Celani (2009, p.9), as pesquisas na área de formação de professores, especificamente de professores de inglês, têm experimentado uma crescente atenção no meio acadêmico:

Embora a história da formação inicial e continuada de professores em geral e de professores de línguas em particular, no Brasil, não seja muito longa, em comparação à de outros contextos, relatos e discussões de pesquisas relativos a educação de professores, tanto inicial quanto continuada, têm se tornado cada vez mais frequentes no âmbito acadêmico.

Apesar dos esforços dos professores, as reformas dos currículos e as novas diretrizes para formação docente e as contínuas falhas no processo de formação nas universidades favoreceram o desenvolvimento de iniciativas que envolvem a formação continuada de professores (STURM, 2007; CAMARGO, 2007; SILVA, 2010 apud STURM, 2011). Pimenta (2005, p.21-22) alega outras razões que ilustram a crescente importância da formação continuada nas últimas décadas:

[...] ganhou força a formação contínua na escola, uma vez que aí se explicitam as demandas da prática, as necessidades dos professores para fazerem frente aos conflitos e dilemas de sua atividade de ensinar. [...] A partir da valorização da pesquisa e da prática no processo de formação de professores, propõe-se que esta se configure como um projeto de formação inicial e contínua articulado entre as instâncias formadoras (universidades e escolas).

Barcelos (2009) enfatiza a difícil situação para os professores depois de terminar seus estudos iniciais, ressaltando que eles são deixados sozinhos, sem qualquer ajuda ou orientação para a sua carreira em andamento. Ela defende uma iniciativa de apoio e de formação continuada para docentes formados recentemente para acompanhá-los na sua prática profissional diária.

Desde os anos 1990, o governo brasileiro vem realizando várias etapas a favor da formação continuada. Segundo Gatti (2008, p.64), foi a criação do Fundeb (Fundo de Manutenção e Desenvolvimento da Educação Básica e de Valorização dos Profissionais da Educação) pelo MEC, em 19989, que ofereceu, “pela primeira vez na história educacional do

\footnotetext{
${ }^{9}$ Retificação: Gatti se refere ao Fundef (Fundo de Manutenção e Desenvolvimento do Ensino Fundamental e de Valorização do Magistério) que vigorou de 1998 a 2006. O Fundeb foi criado, em 2006, em substituição ao Fundef.
} 
país, respaldo legal para o financiamento sistemático de cursos de formação de professores em serviço".

Com base nessas ações políticas, o número dos programas de formação continuada aumentou no final dos anos 90 no Brasil: foram iniciados vários programas de capacitação docente em regiões diferentes do país, dentre os Programas de Capacitação de Professores (Procap, Minas Gerais); o Programa de Educação Continuada (PEC), o Programa de Formação de Professores em Exercício (Proformação), concebido pelo MEC para formar os professores leigos no Centro-Oeste, Norte e Nordeste, e o Projeto Veredas, que é um resultado da parceria entre o governo de Minas Gerais e Instituições de Ensino Superior (IES) (GATTI, 2008).

Numerosos outros esforços nas políticas têm sido feitos nos anos seguintes para melhorar a formação contínua de docentes (disposições da LDBEN/MEC), Rede Nacional de Formação Continuada de Professores de Educação Básica (Rede). Em 2008, a Conferência Nacional da Educação Básica (Coneb), organizada em Brasília, deliberou o estabelecimento de políticas e programas nacionais. Em 2009, o Decreto 6.755 instituiu a Política Nacional de Formação de Profissionais do Magistério da Educação Básica, Plano Nacional de Educação (PNE) (GATTI, 2008).

Apesar de todos esses projetos e outras medidas que foram implementados no Brasil, Celani (2009, p.9) critica um ponto crucial que ela considera responsável pelo pouco êxito dessas iniciativas:

Frequentemente, sempre que um novo projeto, quer na esfera federal, quer em esferas estaduais ou municipais, é idealizado e em seguida implementado, raramente se pensa em, com antecedência, preparar os professores para sua implementação. Parece até que as autoridades, de modo geral, pressupõem que os professores estão sempre capacitados a compreender o novo e a pô-lo em prática sem necessidade de uma especial preparação.

No entanto, existem alguns outros problemas no que diz respeito à implementação de projetos, no contexto atual: Vezub (2007), por exemplo, relata que as iniciativas são feitas isoladamente, pontuais e de curta duração. Além disso, as propostas estão focadas no professor individual, sem considerar nem o seu atual estágio de desenvolvimento profissional, nem os contextos institucionais em que ele atua. Ele também aponta que há uma falta de monitoramento e avaliações sistemáticas a respeito das ações implementadas, resultando em uma descontinuidade das políticas. 
Para Almeida Filho (1995), o termo "formação" já implica o caráter dinâmico e contínuo desse processo. O uso de seu particípio passado, "formado", enganosamente lhe confere um caráter absoluto de ter completado uma determinada qualificação. No entanto, a palavra "formado" só deveria expressar que um professor tem conseguido uma qualificação que o oficialmente autoriza a trabalhar em sua profissão enquanto "formação" pode ser considerado um processo contínuo que deve ser parte de um todo do professor na vida profissional.

Reforçando essa ideia, Candau (2001, p.150) aponta que a formação continuada

[...] não pode ser concebida como um processo de acumulação (de cursos, palestras, seminários etc., de conhecimentos ou de técnicas), mas sim como um trabalho de reflexividade crítica sobre as práticas e de (re)construção permanente de uma identidade pessoal e profissional, em interação mútua. E é nessa perspectiva que a renovação da formação continuada vem procurando caminhos de desenvolvimento.

Moura Filho (2011) considera a formação continuada de professores o ponto de partida para romper o "círculo vicioso" que foi mencionado antes e que descreve as causas da insuficiência da situação atual da formação de professores de Letras no Brasil. Portanto, conforme o mesmo autor, a formação inicial não pode ser considerada um passo final, mas apenas um primeiro passo importante na formação de um professor. A formação continuada é necessária para que os docentes constantemente questionem e promovam suas práticas profissionais que "os tornem, de fato, membros ativos da Sociedade do Conhecimento ${ }^{10}$ e da informação, envolvidos em um fazer educacional transformado e transformador" (MOURA FILHO, 2011, p.50).

Candau (2001) e Santos (1998) também apontam que, no campo da educação, muitos autores concordam que nenhuma formação inicial pode ser considerada suficiente para o desenvolvimento profissional, o que exige um processo de educação continuada, a fim de combinar teoria e prática dos professores. Celani e Collins (2003), que implementaram dois programas de educação continuada para professores de escolas públicas no Brasil, relatam os vários efeitos positivos que resultaram desses programas:

1) uma maior abertura a mudanças;

2) uma maior delicadeza no que diz respeito às necessidades de seus alunos;

3) uma maior persistência quando confrontados com questões difíceis ou novas;

10 "Sociedade onde a criação, o compartilhamento e o uso do conhecimento são fatores indispensáveis à prosperidade e ao bem-estar das pessoas" (MOURA FILHO, 2011, p.50). 
4) uma melhor habilidade para lidar com as novas tecnologias;

5) o desenvolvimento de uma maior dinâmica no que diz respeito às suas práticas de ensino;

6) uma exaltação reforçada para a sua profissão.

Não podemos deixar de refletir que a formação continuada também pode contribuir para fazer jus às exigências que a profissão de professor cria. É evidente na maioria das outras áreas, seja no setor privado ou na administração pública, que as instituições e empresas regularmente treinam seus funcionários, a fim de prepará-los para as mudanças do mundo contemporâneo. Assim, a área da educação está também exposta a essas mudanças e, portanto, deveria reagir diante de tais mudanças que o ambiente de ensino traz constantemente, seja com o aperfeiçoamento de certas habilidades ou com o uso de novas tecnologias, por exemplo.

Reforçando essa ideia, Nóvoa aponta que "só uma reflexão sistemática e continuada é capaz de promover a dimensão formadora da prática. [...] Só o profissional, no entanto, pode ser responsável por sua formação“ (GENTILE, 2003, s.p.). Entendo, ao contrário desse autor, que há mais intervenientes nesse processo.

Nóvoa (1991, p.30) enfatiza que a formação continuada tem que ser realizada no contexto da vida real dos professores e no lugar onde o ensino acontece:

A formação continuada deve estar articulada com o desempenho profissional dos
professores, tomando as escolas como lugares de referência. Trata-se de um objetivo
que só adquire credibilidade se os programas de formação se estruturarem em torno
de problemas e de projetos de ação em torno de conteúdos acadêmicos.

Nóvoa (1991, p.30) menciona um fator importante para uma formação continuada, a experiência dos professores: “A formação continuada deve alicercar-se numa 'reflexão na prática e sobre a prática', através de dinâmicas de investigação-ação e de investigaçãoformação, valorizando os saberes de que os professores são portadores”.

No entanto, a necessidade para uma formação continuada de professores não se baseia exclusivamente em exigências ou problemas específicos, pelo contrário, resulta da própria natureza da profissão docente, como Freire (1991, p.58) descreve: "Ninguém nasce educador ou marcado para ser educador. A gente se faz educador, a gente se forma como educador, permanentemente, na prática e na reflexão da prática”. Pela reflexão dessa citação, ser educador, mais do que um ato de amor, é um investimento na formação. Para o 
desenvolvimento de um bom professor se requer uma aquisição permanente de novas formas de educar para a prática cotidiana. Por isso, são necessários novos conceitos para um modelo moderno de professor.

No contexto de formação continuada de professores, entendo que o peer coaching, como ferramenta para o desenvolvimento da atividade de ensino de línguas, tem alto potencial de eficiência, já que trabalha de maneira interpessoal e considera o grupo de professores como um todo.

\subsection{Coaching}

\subsubsection{Uma breve história}

Nao há consenso na literatura quanto ao surgimento dos primeiros princípios do coaching na história da humanidade. Pode-se imaginar que os relacionamentos de coaching foram existentes desde que as pessoas começaram a apoiar-se mutuamente, a fim de entender melhor o mundo em que viviam. Sócrates, já no século 5 a.C., recomendou “olhar para dentro de si" ${ }^{11}$, quando ele constatou que "aquele que mudaria o mundo primeiro mudaria a si mesmo“"12 (GORNALL; BURN, 2013, p.21).

Coach como profissão parece haver começado no início do século 20, com a quebra de velhas certezas que determinavam a vida até então, como, por exemplo, um sistema de classes e a infalibilidade da ciência, que, consequentemente, resultou no desenvolvimento de novas ideias e oportunidades em áreas da educação, psicologia, esporte, educação de adultos, descrevendo como os seres humanos poderiam alcançar seus objetivos e explorar o seu potencial (GORNALL; BURN, 2013).

Os autores consideram o livro O Jogo de Tênis Interior $^{13}$ (1975) do treinador de esportes americano Timothy Gallwey como altamente influente nesse contexto. Ele descreve como uma pessoa pode se tornar autoconsciente e atenta sobre seu próprio pensamento e suas reações em situações estressantes, vir percebendo seu diálogo interno, a fim de tomar medidas para alcançar a meta destinada. Seu chamado modelo "O jogo interior" 14 foi um marco na

\footnotetext{
${ }^{11}$ do original: Inward looking

12 do original: Let him who would move the world first move himself (Retificação: Sócrates, enquanto personagem de Platão. Cf., por exemplo, o diálogo Cármides (160d5-6))

${ }^{13}$ do original: The Inner Game of Tennis

${ }^{14}$ do original: The inner game
} 
história do coaching e serviu como um guia não apenas para muitos atletas, mas também o foi, mais tarde, para profissionais que viam no coaching um modelo de coaching GROW ${ }^{15}$ que foi amplamente aplicado na área do coaching corporativo na década de 1980, e especialmente, na de 1990.

Foi também o ramo das humanidades que teve uma forte influência sobre o desenvolvimento do coaching. O psicólogo americano Carl Rogers, um dos fundadores do chamado person-centered counselling (aconselhamento centrado na pessoa), mudou radicalmente o modelo predominante de tratar doenças psicológicas, colocando o paciente no foco do processo de tratamento, acreditando fortemente na capacidade do paciente de alcançar o seu próprio potencial, a fim de curar e crescer, com o médico só fornecendo as condições para o tratamento. A convicção humanista de que os seres humanos naturalmente são bons e têm a capacidade de tomar decisões sobre suas próprias vidas e, portanto, de repensar essas decisões novamente, reforça a crença de muitos "Treinadores"16 que acreditam que os Coachees $^{17}$ têm o potencial para alcançar metas, trabalhando de forma colaborativa (GORNALL; BURN, 2013).

O coaching teve um forte impulso nas últimas décadas, os coaches tornaram-se um componente fixo em quase todas as áreas da vida moderna, tais como negócios, saúde e educação. Várias organizações profissionais de coaching cresceram, como por exemplo, a International Coach Federation (ICF), criada em 1995 nos EUA, que atualmente ultrapassa mais de 20.000 membros de todo o mundo.

Depois desta breve descricão da história do coaching, explicitarei as diferenças entre coaching e mentoring, na seção seguinte.

\subsubsection{Coaching - mentoring}

Gornall e Burn (2013) constatam que, etimologicamente, o termo inglês coach é derivado de um meio de transporte puxado por cavalos, que traça as suas origens à palavra húngara kócs (carruagem), e que foi o nome da vila onde essa carruagem foi inicialmente elaborada e construída. Araújo (1999) descreve um coach como uma pessoa que dá apoio para

\footnotetext{
${ }^{15}$ GROW: G-Goal (Objetivo); R - Reality (Realidade); O-Options (Opções); W-Wrap up (Encerramento).

${ }^{16}$ do original: Coaches

${ }^{17}$ Essa expressão não possui uma tradução literal para o português. Ela se refere ao indivíduo que é guiado pelo treinando.
} 
alguém que possui um determinado objetivo a alcançar. Já para Wolk (2008), o conceito de coaching é mais profundo do que simplesmente um treinamento; ele se refere a algo que possa ser comparado a um tipo de arte, a um processo de aprendizagem que, além da autorreflexão, demanda uma profunda mudança interior, resultando em redefinição das crenças e dos modelos de um indivíduo.

Explicando a origem do conceito de mentoring, muitos autores referem-se a "Odisséia”, de Homero, na qual o mentor, uma figura de proteção, orientação e suporte age como um conselheiro sábio e confiável para Telêmaco, filho do rei Odisseu, durante sua longa ausência da casa (ROBERTS, 1999). Carruthers (1993, p.9) acrescenta mais uma perspectiva a isso, dizendo que "[...] O Mentor tinha que ser uma figura de pai, um professor, um modelo, um conselheiro acessível, um conselheiro de confiança, um provocador, um encorajador."18

Os dois conceitos de coaching e mentoring têm muitas características em comum: no contexto da educação ambos ajudam as pessoas envolvidas a acessarem a autoconsciência, para reforçar a sua motivação e dar um apoio emocional, a fim de atingir determinados objetivos, segundo Clutterbuck (2010). Ele constata que ambas as abordagens se concentram em alcançar uma mudança, aproveitando-se de processos que os coachees podem gerenciar por si mesmos. Estes processos consistem em:

- $\quad$ sensibilizar o coachee sobre o que está acontecendo;

- ajudar o coachee por meio do processo de compromisso;

- articular a crença na capacidade do coachee de possibilitar uma mudança;

- apoiar o coachee nos momentos de recaída;

- trabalhar sobre a qualidade do seu pensamento.

No entanto, devido a essas semelhanças, os dois termos são frequentemente confundidos, por isso, a seguir explico as principais diferenças. Segundo Landsberg (1996), o coaching busca estimular a capacidade do desempenho e do processo de aprendizagem de outros. Isto pode ser conseguido proporcionando feedback ou usando técnicas como motivação e questionamento eficaz, por exemplo. Coaching não é sobre o coach falando e dando instruções, é baseado em apoiar o coachee para ajudar-se a si mesmo por meio da interação dinâmica.

\footnotetext{
18 do original: (...) Mentor had to be a father figure, a teacher, a role model, an approachable counsellor, a trusted adviser, a challenger, an encourager.
} 
Barkley (2005, p.4) constata que, no contexto da educação, o coaching

[...] oferece, aos professores, um meio que é usado para alcançar metas, melhorar as estratégias e fazer uma diferença para os alunos e colegas. Com o coaching, os professores descobrem, geralmente, pela primeira vez, como refletir sobre o seu ensino de forma que agreguem valor aos seus métodos e um maior nível de profissionalismo. Eles se veem e se ouvem como educadores. Eles têm, também, oportunidades de receber feedback direto sobre como eles interagiram com seus alunos e, ainda, eles aumentam a própria capacidade de elaborar planos de aula que se concentram em estratégias específicas que eles querem implementar para alcançar todos os seus alunos. ${ }^{19}$

Contrariamente ao coaching, Podsen e Denmark (2007) definem o mentoring como uma relação permanente entre um novato e um especialista, em que é claramente definido que o especialista (respectivamente o mentor) fornece ajuda, apoio e orientação para que o novato desenvolva as habilidades que são necessárias para entrar ou continuar em sua carreira. As duas principais funções do mentor são: atuar como modelo e como especialista em seu campo de ensino. Assim, de acordo com Barkley (2005), um programa de mentoring geralmente consiste em tarefas específicas que são atribuídas ao mentor, que podem ser de natureza técnica, curricular ou comportamental.

Clutterbuck (2010) ilustra as diferenças das duas abordagens. Ele fala que o coaching é de duração mais curta, com a intenção de trabalhar em objetivos específicos, que podem ser desencadeados por um determinado problema ou uma oportunidade, enquanto o mentoring concentra-se na obtenção de metas de longo prazo e tem uma agenda mais aberta. Comparado ao coaching, o processo de mentoring consiste em um espectro mais amplo de atividades, como, por exemplo, ajudar o mente $e^{20}$ a desenvolver o seu próprio repertório de recursos. Enquanto que o coaching dá uma resposta para a pergunta em que o coachee quer melhorar, o mentoring visa responder à pergunta em quê (ou quem) o mentee quer tornar-se, ou seja, uma mudança mais holística.

Para Barkley (2005), a diferença fundamental entre coaching e mentoring é que o coach não precisa necessariamente ter uma maior competência profissional na área de atuação do coachee, enquanto o mentoring exige essa competência.

\footnotetext{
${ }^{19}$ do original: [...] provides a vehicle by which to achieve goals, improve strategies, and make a difference for students and colleagues. With coaching, teachers discover - usually for the first time - how to reflect on their teaching in ways that add value to their methods and an enhanced level of professionalism. They see and hear themselves as educators. They get opportunities for receiving direct feedback on how they have interacted with their students. They increase their ability to design lesson plans that focus on specific strategies they want to implement to reach all their students.

${ }^{20}$ Essa expressão não possui uma tradução literal para o português. Ela se refere ao indivíduo que é guiado pelo mentor.
} 
Na seção seguinte, apresento um olhar mais detalhado na constelação coach - coachee - pesquisador e as suas responsabilidades no contexto do projeto da pesquisa subjacente.

\subsubsection{Coach-coachee - pesquisador}

Segundo Clutterbuck (2010), o papel adequado, os comportamentos e as características que um coach precisa assumir dependem de uma variedade de circunstâncias e de outros fatores, como a complexidade de uma tarefa, o nível de prontidão do coachee no início do processo, a sua autoconfiança e capacidade no que diz respeito à tarefa. $\mathrm{O}$ autor completa essa primeira definição ao afirmar o seguinte:

Coaches atuam como estimuladores externos para o potencial que outras pessoas
tenham dentro de si. Eles usam uma combinação de paciência, perspicácia,
perseverança e carinho (às vezes chamado carisma) para ajudar $o(s)$ coachee $(s)$ a
encontrarem os recursos internos e externos para melhorar o desempenho
(CLUTTERBUCK, 2010, p.9 9$)^{21}$.

Por fim, o mesmo autor também levanta a questão sobre quais habilidades o coach e o coachee precisam para trabalhar juntos de forma eficiente e bem-sucedida. Para ele, o coaching pode acontecer em três níveis de operação diferentes que são associadas com diversas competências que um coach precisa:

- O coaching dia-a-dia: feito por um superior ou um colega no local de trabalho, por exemplo (competências: as habilidades básicas de ouvir e observar, motivar e encorajar, dentre outros);

- O coaching para melhorar certas habilidades físicas, técnicas ou comportamentais (competências: conhecimentos avançados de ouvir e dar feedback, o conhecimento especializado na área de desempenho, a compreensão de aprendizagem e de teorias motivacionais, dentre outros);

- O coaching para um indivíduo a fim de realizar uma transformação pessoal (competências: o conhecimento amplo sobre modelos de coaching e habilidades de aconselhamento, por exemplo).

No entanto, a fim de facilitar um processo de coaching profundo e valioso, o coachee deve ser capaz, ainda segundo Clutterbuck (2010), pelo menos em certa medida, de

\footnotetext{
${ }^{21}$ do original: Coaches act as external stimulators to the potential that other people hold within them. They use a combination of patience, insight, perseverance and caring (sometimes called charisma) to help the coachee(s) find the internal and external resources to improve performance.
} 
- falar sobre seus problemas, suas expectativas e os avanços alcançados durante o processo;

- darfeedback sobre o problema antes e depois das sessões de coaching;

- escutar ativamente e estar aberto para os elementos racionais e emocionais do problema;

- aprender de forma proativa, entre outras.

Para Gottesman (2000), o peer coaching implica dois colegas, do mesmo nível, treinando um ao outro. O autor descreve as características exigidas pelos professores (respectivamente o coach e coachee) a fim de realizar um programa de peer coaching com sucesso: ambos precisam ter uma mente aberta e devem estar interessados em descobrir melhores e novas maneiras para atuar na sala de aula. Eles precisam estar comprometidos com o peer coaching, ambos atuando no papel de colega e profissional ao mesmo tempo, e tentando discutir seu ensino sem elogiar e culpar seu par. Também precisam estar cientes de que a procura de formas alternativas e a melhora de suas habilidades não é uma forma de admitir fraqueza, muito pelo contrário: o objetivo final de todas as considerações e ações realizadas pretendem beneficiar seus alunos.

Na pesquisa aqui relatada, as responsabilidades dos três participantes são refletidas na seguinte constelação: coach - coachee - pesquisador, como mostra a figura 1. O peer coaching em si não é feito pelo pesquisador, é feito pelos peers (o coach e o coachee) que são convidados pelo pesquisador para assumir o papel de coach e coachee mutuamente, a fim de treinar e apoiar um ao outro. O pesquisador deve agir como um modelo crítico e positivo para fornecer um ambiente em que o coaching possa ser considerado como uma parte integrante da vida do dia-a-dia.

Assim, oriento, no meu papel ativo como pesquisador, o processo de peer coaching em suas diferentes etapas, sugerindo diferentes atividades e oferecendo apoio prático para o coach e o coachee, ajudando-as a avançar no projeto, agindo no papel de um motivador e consultor no sentido de estabelecer e manter a comunicação entre as participantes e fornecer atualizações sobre as tarefas, a fim de mantê-las no caminho de ajuda mútua. 


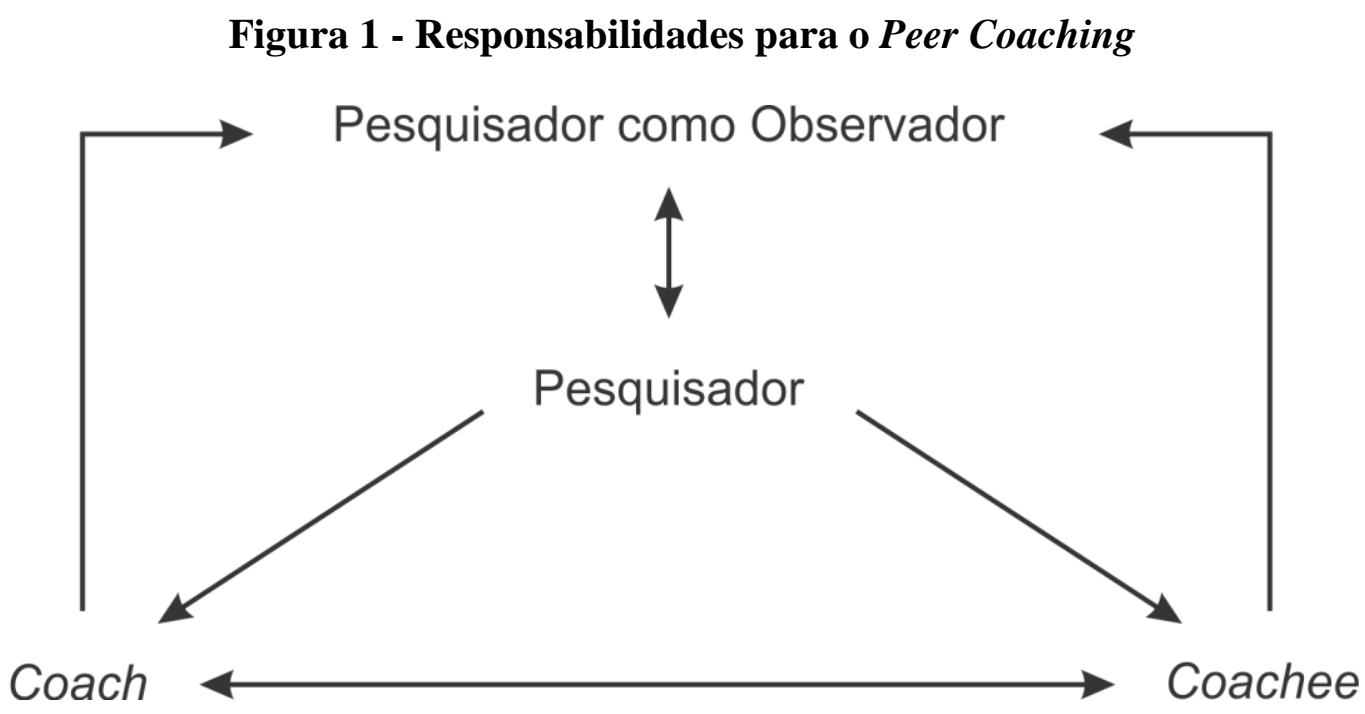

No meu segundo papel de pesquisador como observador, supervisiono o andamento do projeto e reflito sobre as atividades e os resultados dele a fim de adaptar o processo da pesquisa. Essa constelação reflete os princípios subjacentes à ideia que fundamenta minha pesquisa no dado texto, com base nos critérios mencionados anteriormente.

\subsection{Peer Coaching}

\subsubsection{Uma breve história}

No contexto de formação continuada de professores, o princípio do peer coaching entra em vigor como uma ferramenta para o desenvolvimento profissional (SHOWERS; JOYCE, 1996).

A influência dos educadores e pesquisadores norte-americanos Beverly Showers e Bruce Joyce pode ser considerada uma das maiores contribuições ao surgimento do peer coaching. Os autores (1996) constatam que o peer coaching tem suas raízes primordiais tanto no mundo do atletismo quanto na transferência de formação e remontam sua origem na área da educação na década de 1950 nos Estados Unidos, emergindo de movimentos nacionais que focaram na melhoria da qualidade acadêmica e da igualdade social.

No entanto, percebeu-se logo que estes esforços raramente levavam a mudanças efetivas. Já durante a década de 1970, as avaliações de desenvolvimento pessoal, 
concentrando-se nas estratégias de ensino e currículo, revelaram que apenas $10 \%$ dos participantes implementaram o que tinham aprendido:

Na década de 1970, as avaliações de desenvolvimento de pessoas, que focalizaram as estratégias de ensino e currículo, revelaram que apenas $10 \%$ dos participantes implementaram o que tinham aprendido. As quotas de transferência foram baixas, mesmo para aqueles que se ofereceram para o treinamento ${ }^{22}$ (SHOWERS; JOYCE, 1996, p.12).

Isso, de acordo com os autores, deveu-se à falta de conhecimento sobre como os professores aprendem estratégias de ensino e como as escolas podem divulgar inovações com sucesso. Em vez disso, assumiu-se que a falta de motivação, o esforço ausente e a atitude errada dos professores foram as razões para esse fracasso.

Inicialmente, Joyce e Showers (1980) acreditavam que uma combinação de modelar, de praticar sob condições simuladas, de praticar em sala de aula e de realizar o feedback poderia ser a forma de coaching mais produtiva. Na década de 1980, essa crença se mostrou verdadeira quando confirmaram a hipótese de que o coaching, como sequência do treinamento inicial, resultaria em uma transferência de conhecimento muito maior do que treinar sozinho (SHOWERS; JOYCE, 1996).

Com base nessas descobertas, os mesmos autores (1996) incluíram o peer coaching em seus programas de formação de professores e ainda conseguiram implementá-lo em algumas escolas envolvendo todo o corpo docente. O sucesso dessas iniciativas é realmente notável:

\begin{abstract}
O coaching ajudou quase todos os professores a implementarem novas estratégias de ensino. Igualmente importante, os professores que foram apresentados aos novos modelos poderiam treinar um ao outro, desde que eles continuassem a receber um acompanhamento periódico em contextos de formação. Assim, recomenda-se que as escolas organizem equipes de professores de peer coaching e disponibilizem ambientes escolares adequados para que os mesmos possam trabalhar juntos a fim de ganharem habilidades suficientes para atingir o processo de aprendizadem do aluno. Deixamos para trás os anos 1950 e 1960, quando a probabilidade de implementação era extremamente baixa, e passamos para uma fase com tecnologia muito simples, o que praticamente inverteu as probabilidades $^{23}$ (SHOWERS; JOYCE, 1996, p.14).
\end{abstract}

\footnotetext{
22 do original: In the 1970s, evaluations of staff development that focused on teaching strategies and curriculum revealed that as few as 10 percent of the participants implemented what they had learned. Rates of transfer were low even for those who had volunteered for the training.

${ }^{23}$ do original: Coaching helped nearly all the teachers implement new teaching strategies. Equally important, teachers introduced to the new models could coach one another, provided that the teachers continued to receive periodic follow-up in training settings. Thus we recommended that schools organize teachers into peer coaching teams and arrange school settings so that the teachers could work together to gain sufficient skill to affect student learning. We had moved from the '50s and '60s, where the probability of implementation was extremely low, to a very simple technology that virtually reversed the odds.
} 
Da mesma maneira que o peer coaching evoluiu como um meio alternativo de avaliação e melhoria dos professores, diferentes conceitos surgiram nas últimas décadas, que serão explicitadas na seção seguinte.

\subsubsection{Modalidades do peer coaching}

Antes de dar uma olhada mais atenta às diferentes modalidades que o peer coaching pode assumir, coloco uma definição inicial, a fim de ilustrar os princípios básicos desse processo formativo:

Peer coaching é um processo confidencial, através do qual dois ou mais colegas de profissão trabalham juntos para refletir sobre as práticas correntes; expandir, refinar e desenvolver novas habilidades; compartilhar ideias; ensinar uns aos outros; conduzir a pesquisa em sala de aula; ou resolver problemas no local de trabalho ${ }^{24}$ (ROBBINS, 1991, p.1).

Segundo Robbins (1991, p.1), outros nomes para peer coaching têm evoluído ao longo dos anos, como por exemplo, o peer support (apoio de pares), consulting colleagues (colegas consultores), peer sharing (partilhar entre pares) e care (cuidar). Isso também se deve ao fato de que a palavra coaching ainda causa certo tipo de desconforto para muitos professores, porque implica desigualdade entre os colegas.

Mas, na verdade, é justamente isso que não deveria acontecer. O ponto mais importante do peer coaching é que o status de igualdade profissional entre pares remove a importante dimensão de poder que é evidente em outras relações. Assim, os indivíduos que estão no mesmo nível podem fornecer comunicações horizontais críticas, como descrito por Siegel (2000). Robbins (1991, p.7), por sua vez, aponta alguns princípios básicos do peer coaching: "Apesar do tipo ou da abordagem, todos os esforços do peer coaching compartilham uma busca colaborativa para aperfeiçoar, expandir e melhorar o conhecimento sobre a profissão docente". 25

Joyce e Showers (1980) descrevem duas abordagens gerais do peer coaching: a primeira é baseada na formação de uma estratégia ou método específico para os professores implementarem novas habilidades que aprenderam durante um treinamento. $\mathrm{O}$ foco nesta

\footnotetext{
${ }^{24}$ do original: Peer Coaching is a confidential process through which two or more professional colleagues work together to reflect on current practices; expand, refine, and build new skills; share ideas; teach one another; conduct classroom research; or solve problems in the workplace.

${ }^{25}$ do original: Regardless of the type or approach, peer coaching efforts all share a collaborative quest to refine, expand, and enhance knowledge about the teaching profession.
} 
abordagem de peer coaching está diretamente relacionado ao conteúdo da sessão de orientação, que, finalmente, resulta numa transferência de habilidades. No entanto, a aplicação dessa abordagem como forma exclusiva de peer coaching ao longo do tempo pode resultar no desenvolvimento de certa rotina que transforma o processo de coaching em uma prática que carece de reflexão (HARGREAVES, 1989).

Robbins (1991) diz que a segunda abordagem de peer coaching é baseada em um foco especificado pelo professor, que - em contraste com o primeira abordagem - tem a intenção de trabalhar de forma colaborativa em torno de questões que não tenham surgido de orientação precendente. Em vez disso, as abordagens desse segundo tipo de peer coaching devem estimular a partilha profissional, aperfeiçoar as práticas de ensino e promover a reflexão dos professores. As atividades podem incluir a resolução de problemas específicos com a instrução, a elaboração de currículos e também os problemas com alunos.

Robbins (1991) afirma que as atividades de peer coaching necessariamente precisam ter um foco deliberado, com base no que realmente importa para os indivíduos envolvidos, a fim de alcançar um efeito permanente ao longo do tempo. A abordagem de peer coaching, na qual minha pesquisa se baseia, pertence ao segundo tipo descrito acima, e coloca o indivíduo e as questões que são importantes e relevantes para ele no foco da pesquisa.

$\mathrm{Na}$ seção a seguir, apresento diferentes formas que o peer coaching pode assumir.

\subsubsection{Operacionalizações do peer coaching}

Segundo Robbins (1991, p.2), “o peer coaching é tão individual e único como as pessoas que se dedicam a ele". ${ }^{26}$ Por isso, é importante entender as diferentes maneiras, que ele pode ser empregado, a fim de escolher as melhores alternativas para cada contexto.

Ainda segundo o mesmo autor, existem algumas maneiras de realizar o peer coaching, com as caraterísticas e atividades correspondentes que estão subjacentes a essas maneiras. O autor constata que uma dessas é shared observation (observação compartilhada), que pode ser realizada em pequenos grupos de professores. Normalmente, essa atividade consiste em uma pré-conferência, a observação da lição, e a pós-conferência. O professor cuja classe é observada por seus peer( $(s)$ está no controle do processo: ele determina o dia, a hora e o foco da observação e a forma como os dados são recolhidos por seus colegas, entre outros.

\footnotetext{
${ }^{26}$ do original: peer coaching is as individual and unique as the people who engage in it.
} 
Outra possibilidade de aplicar peer coaching é na forma de conduzir a pesquisa-ação: um professor formula um conjunto de hipóteses em relação a certas práticas de sala de aula. Depois essas hipóteses são testadas em sala de aula, com a ajuda de outro professor, que observa e toma notas. Em seguida, esses dados são analisados e discutidos com outros professores (ROBBINS, 1991).

Outra atividade que é sugerida por Shulman (1991) é o storytelling (narração de histórias) sobre experiências de ensino, oferecendo aos professores a possibilidade de compartilhar o conhecimento de sua vida profissional. Segundo o autor, essa maneira especial de compartilhar experiências permite aos professores aumentar seus repertórios técnicos dentro de um contexto descontraído, não ameaçador. O caráter colaborativo do relato de histórias faz com que os participantes se sintam confortáveis e ao mesmo tempo os impede de perceber essa atividade como sendo um aconselhamento, o que poderia ser percebido negativamente.

Caro (1991) sugere outra atividade chamada talk walking (conversar enquanto caminha), que, segundo o autor, visa a promover o diálogo entre colegas em relação a questões curriculares e instrucionais. Os professores podem simplesmente marcar um encontro para uma caminhada e refletir sobre planos de aula, o comportamento de um aluno específico, ou compartilhar qualquer outra experiência que eles fizeram dentro da sala de aula. Usado em um workshop, talk walking também pode apoiar a aprendizagem de novos conteúdos, combinando-os com o conhecimento já existente do professor. Os participantes podem emparelhar-se para uma caminhada e discutir os conteúdos recém-adquiridos, refletindo sobre como eles iriam aplicá-los em suas próprias salas de aula.

Outras atividades colaborativas que o peer coaching pode envolver, segundo Robbins (1991), são o desenvolvimento curricular e o planejamento de aulas, conduzido por pares ou em pequenos grupos de estudo. Os professores também podem reunir-se a fim de resolver problemas específicos dentro da sala de aula ou analisar vídeos de aulas gravadas, por exemplo. Nesse contexto, o autor não se esquece de mencionar que o peer coaching pode ser realizado entre professores com diferentes níveis de experiência, entre especialistas e novatos.

De acordo com Robbins (1991), as formas que o peer coaching pode assumir são ilimitadas e elas podem ser realizadas dentro e fora da sala de aula, por dois ou mais professores trabalhando em conjunto. No entanto, independentemente da forma que o peer 
coaching assume, o foco é sempre o professor como um aprendiz (FULLAN, BENNETT e ROLHEISER-BENNETT, 1990).

Por isso, a escolha das atividades de peer coaching da pesquisa aqui relatada foi feita por mim em conjunto com as professoras participantes da escola de línguas UnB Idiomas, sempre considerando o contexto da pesquisa e estando ciente das necessidades das docentes. Esse assunto será desenvolvido mais à frente nesta dissertação, especificamente no Capítulo 4 .

\subsubsection{As contribuições do peer coaching}

Segundo Kennedy (2005), o peer support e a colaboração desempenham muitos papéis. Muitos professores são suscetíveis de ficar mais à vontade para discutir sua prática com os colegas do que com seus superiores hierárquicos, quando questões que envolvem a gestão de desempenho podem dificultar a discussão honesta e aberta.

Gottesman (2000) propõe o peer coaching como ferramenta descomplicada e nãoameaçadora que oferece uma possibilidade entre colegas de apoiar um ao outro ao encontrar formas de melhorar as situações nas quais a instrução e a aprendizagem acontecem.

No entanto, como descrito por Almeida Filho (2009), as formas tradicionais de supervisão e orientação de professores de LE (muitas vezes descrita como "coaching") demasiadas vezes limitam-se a observação de aulas, as observações feitas num relatório, ou também ao preenchimento de formulários preparados anteriormente que apenas enfocam certos pontos que haviam sido definidos com antecedência, que consequentemente resultam em uma falta de análise crítica dos dados coletados e que também impedem um diagnóstico crítico e uma tomada de ações adequadas.

Barth (2000), por sua vez, destaca outra vantagem do peer coaching, que é o fato de que esse processo é não-avaliativo, voluntário e amplamente controlado pelo coachee, atribuindo, assim, a possibilidade de tomar posse por si mesmo, onde essa forma difere de formas tradicionais de supervisão. Isso torna possível, tanto para o coach quanto para o coachee tomarem a iniciativa, guiando-se para onde vão, para, finalmente, beneficiarem-se de apoio mútuo e de aprendizagem profissional.

Em contraste com as formas tradicionais de supervisão que enfocam o controle da qualidade, onde, em muitos casos, efeitos de apenas curto prazo foram observados, o conceito 
de peer coaching resulta em uma redução do isolamento e, além disso, prevê o crescimento profissional dos professores, criando habilidades reflexivas e analíticas (GOTTESMAN, 2000).

Baker e Showers (1984) descrevem o peer coaching com um processo no qual os profissionais da educação ajudam um ao outro na negociação da distância entre a aquisição de novas habilidades ou estratégias de ensino para aplicá-las com habilidade e eficiência para a instrução. Eles apontam que professores que tinham um relacionamento de coaching praticaram novas habilidades e estratégias com mais frequência e as aplicaram de forma mais adequada do que os seus colegas que trabalhavam sozinhos:

Os resultados de nossos estudos iniciais mostraram que os professores que tinham um relacionamento de coaching - isto é, que compartilharam os aspectos de ensino, planejado em conjunto, e reuniram suas experiências - praticaram as novas habilidades e estratégias mais frequentemente e as aplicaram de forma mais adequada do que os seus colegas que trabalhavam sozinhos para expandir seus repertórios. Os membros de peer coaching apresentaram uma maior retenção de novas estratégias a longo prazo e a utilização mais adequada dos novos modelos de ensino ao longo do tempo ${ }^{27}$ (BAKER; SHOWERS, 1984, p.2-3).

Becker (2011) também descreve vários efeitos positivos do peer coaching, como, por exemplo, um melhor/maior desempenho progressivo dos alunos desses professores, um melhor senso de competência profissional, um aumento da capacidade de analisar suas próprias lições e um maior repertório de estratégias/recursos instrucionais, só para citar alguns.

Para Robbins (1991) há varias razões para utilizar o peer coaching:

- a redução do isolamento entre os professores;

- a construção de normas de colaboração para permitir aos professores darem e receberem ideias e assistência;

- a criação de um fórum para abordar os problemas de instrução;

- o compartilhamento das práticas bem sucedidas;

- a transferência da orientação da oficina para o local de trabalho;

\footnotetext{
${ }^{27}$ do original: Results of our early studies showed that teachers who had a coaching relationship - that is, who shared aspects of teaching, planned together, and pooled their experiences - practiced new skills and strategies more frequently and applied them more appropriately than did their counterparts who worked alone to expand their repertoires. Members of peer-coaching groups exhibited greater long-term retention of new strategies and more appropriate use of new teaching models over time.
} 
- a promoção do professor como pesquisador;

- o incentivo para uma prática reflexiva.

O peer coaching tem o potencial de melhorar a vida profissional dos docentes de várias maneiras diferentes. $\mathrm{O}$ aumento da colaboração entre os professores de uma escola promove o compartilhamento de informações sobre o ensino e a aprendizagem e o desenvolvimento de um ambiente que apoia a experimentação e a tomada de riscos. Segundo Robbins (1991), por ter um maior apoio em sua escola, os professores sentem-se menos isolados e se beneficiam por terem a possibilidade de ensinar uns aos outros e partilhar recursos para a instrução e o currículo.

Para Gottesman (2000), o peer coaching dá aos professores a oportunidade de discutir suas lições profundamente e torna visíveis as coisas que eles fazem instintivamente, permitindo-lhes ampliar os seus conhecimentos de ensino e de coaching. Os professores recebem feedback de outros professores que lhes respeitam e, muitas vezes, aprendem melhor atuando no papel do coach do que no de coachee.

No nível institucional, de acordo com Gottesman (2000), o peer coaching pode fornecer um panorama confiável para a troca de experiências sobre problemas instrucionais, um sistema de apoio mútuo que aumenta o respeito, tanto em nível pessoal quanto profissional. Em vez de ser treinado por pessoas que não ensinaram por um longo tempo, ou que possivelmente nunca ensinaram, o peer coaching promove a transferência de conhecimentos e habilidades entre os professores da mesma instituição, aumentando, assim, a confiança e o respeito mútuo. A autora resume de forma clara, e ao mesmo tempo drástica, os efeitos potenciais que o peer coaching pode ter em nível institucional:

Nas escolas bem-sucedidas, os colegas vão compartilhar habilidades, práticas e conhecimentos uns com os outros para o bem do aluno. As "cavernas" terão paredes com janelas e portas abertas acolhedoras. O estacionamento não será mais o único terreno comum da escola. As discussões na sala dos professores focarão em instrução em vez de ser o "clube da fofoca": resmungar, fofocar e reclamar ${ }^{28}$ (GOTTESMAN, 2000, p. 38).

Todas as possibilidades e atividades do peer coaching visam melhorar a qualidade do ensino e o crescimento profissional, permitindo a uma escola construir uma comunidade de

\footnotetext{
${ }^{28}$ do original: In successful schools, colleagues will share skills, practice, and knowledge with each other for the good of the student. The "caves" will have walls with open windows and welcoming doors. The parking lot will no longer be the school's only common ground. Discussions in the lounge will focus on instruction instead of being the NBC Club: the nag, bitch, and complain club.
} 
professores que estão comprometidos com a aprendizagem ao longo da vida inteira (BARTH, 1990). Gottesman (2000), por sua vez, afirma que o peer coaching contribui para esse objetivo, como qualquer tipo de discussão, traz o processo de aprendizagem para frente, o que, no final, beneficia todo processo de ensino-aprendizagem, especialmente o aluno em sala de aula.

No capítulo a seguir, apresento o referencial metodológico que dá suporte à pesquisa relatada nesta dissertação. 


\section{METODOLOGIA DA PESQUISA}

Este capítulo tem como objetivo descrever os procedimentos metodológicos que foram utilizados durante a pesquisa para reunir e analisar os dados que compõem o corpus.

Desenvolvi uma pesquisa qualitativa e interpretativista, na modalidade pesquisaação, a fim de responder as perguntas que integram a pesquisa relatada nesta dissertação. Desse modo, busco investigar os dados em seu contexto natural, sendo o pesquisador o principal ator na interpretação dos registros obtidos (ERICKSON, 1986).

A seção a seguir descreve os princípios da pesquisa qualitativa bem como da pesquisa-ação, seguido pela apresentação do contexto da pesquisa e dos participantes e indicação dos procedimentos para a coleta de dados e a análise dos mesmos.

\subsection{O Paradigma Qualitativo}

Denzin e Lincoln (1994) afirmam que a pesquisa qualitativa tem uma história longa e respeitada nas disciplinas das ciências humanas, tais como a sociologia e a antropologia, desde os anos 1920 e 1930, logo seguidas por outras disciplinas das ciências sociais como a educação e o serviço social, apenas para citar algumas.

Além de estudos de caso (HATCH, 1978), as discussões sobre a pesquisa qualitativa foram quase inexistentes em livros da Lingüística Aplicada antes de 1989. A expansão atual dessa abordagem nos últimos anos reflete as tendências em ciências da saúde, ciências sociais, humanidades e educação bem como um crescente interesse em validade ecológica e na natureza social, cultural, situacional, abrangente e performativa da linguagem, do conhecimento e da aquisição (DENZIN; LINCOLN, 1994; LE COMPTE, MILLROY; PREISSLE 1992; MILES; HUBERMAN, 1994, apud DUFF, 2002).

As pesquisas qualitativas são baseadas numa suposição de que o mundo deriva da compreensão de que é construído por pessoas em contato com a realidade e em diferentes interações humanas e sociais. Elas, necessariamente, precisam basear-se em uma análise e uma interpretação dos fatos que revelam os significados atribuídos a esses fatos por pessoas que partilham deles (CHIZZOTTI, 2006).

A pesquisa qualitativa não dá preferência a uma única prática metodológica específica, nem recorre a uma coleção própria de métodos ou práticas (DENZIN; LINCOLN, 
2006). Segundo Chizzotti (2006, p.28), “os instrumentos necessários para se atingir o conhecimento devem estar nos meios de se coletar informações vividas pelos atores humanos dos fatos e qualquer paradigma deve recorrer à intuição humana e à inferência interpretativa".

O mesmo autor (2006) afirma que a pesquisa qualitativa aproveita-se de métodos numerosos de investigação para estudar um fenômeno no local em que ele ocorre, a fim de revelar o sentido do fenômeno bem como interpretar os significados que as pessoas atribuem a eles. Ele não deixa de comentar que, cada vez mais, pesquisadores mostram um crescente interesse nos fundamentos e nas possibilidades da pesquisa qualitativa, o que também se reflete em um número considerável de cursos, textos, artigos e pesquisas que se baseiam nos pressupostos qualitativos.

Denzin e Lincoln explicam que os pesquisadores estudam coisas em seus ambientes naturais, tentando entender e interpretar os fenômenos no que diz respeito aos significados que as pessoas dão a eles. Por isso, nesta investigação, adoto o conceito de pesquisa qualitativa como é vista sob a perspectiva de Denzin e Lincoln (2006, p.17):

[...] a pesquisa qualitativa é uma atividade situada que localiza o observador no mundo. Consiste em um conjunto de práticas materiais e interpretativas que dão visibilidade ao mundo. Essas práticas transformam o mundo em uma série de representações incluindo as notas de campo, as entrevistas, as conversas, as fotografias, as gravações e os lembretes. Nesse nível, a pesquisa qualitativa envolve uma abordagem naturalista, interpretativa, para o mundo, o que significa que seus pesquisadores estudam as coisas em seus cenários naturais, tentando entender, ou interpretar os fenômenos em termos dos significados que as pessoas a eles conferem.

Após ilustrar diferentes aspectos da pesquisa qualitativa, descrevo, na seção seguinte, as características da pesquisa-ação.

\subsection{Pesquisa-Ação}

A modalidade de pesquisa qualitativa na qual se fundamenta o estudo relatado nesta dissertação é pesquisa-ação (action research). Muitos autores consideram o psicólogo alemãoamericano Kurt Lewin como o verdadeiro criador da pesquisa-ação (EL ANDALOUSSI, 2004). Lewin perseguiu o objetivo de melhorar a vida dos grupos desfavorecidos da sociedade, e foi especialmente a combinação de ação e pesquisa do trabalho dele que atraiu pesquisadores tanto da área acadêmica quanto educacional (COHEN; MANION; MORRISON, 2011). 
Segundo El Andaloussi (2004), as teorias de Lewin já influenciaram amplamente o domínio do ensino, em níveis teórico e prático. Além disso, “a pesquisa-ação estimula o desenvolvimento dos poderes do pensamento reflexivo da discussão, da decisão e da ação das pessoas comuns, que participam em uma pesquisa coletiva sobre os distúrbios particulares que elas têm em comum" (ADELMAN, 1989, p.15).

De acordo com Zeichner (2001) e Hopkins (2002), a pesquisa de Lewin em questões sociais é frequentemente descrita como um marco importante no desenvolvimento da pesquisa-ação como metodologia. No entanto, há outros que atribuem as origens dessa prática particular de pesquisa para as obras bem anteriores de pesquisadores como Mayo, Roethlisberger e Dickson (HESS, 1983 apud EL ANDALOUSSI, 2004).

Dewey, em sua escola experimental de Chicago, pretendeu formar educadores e crianças dentro de um programa chamado Project Method:

O espírito pode desenrolar uma verdadeira atividade somente para algum objetivo que tenha em vista, para alguma dificuldade que deve ultrapassar, algum problema que deva resolver, alguma idéia a definir, algum plano a formular (DEWEY, 1929, p.74).

Diggins (1994) considera o fundamento da abordagem da pesquisa-ação a filosofia do Pragmatismo mencionado anteriormente. De todas as caraterísticas desse Pragmatismo, segundo Denzin e Lincoln (2006), são a criação do conhecimento, por meio da ação, a experimentação no presente contexto e a democracia participativa como método e meta os parâmetros que ressaltam nitidamente.

Segundo Bassey (1998), a pesquisa-ação pode ser aplicada em praticamente qualquer ambiente onde um problema que envolve pessoas, tarefas e procedimentos exigem uma solução, ou quando alguma alteração de recursos resulta em um resultado mais desejável. Para Ferrance (2000) a justificativa da pesquisa-ação se baseia nos princípios de que os professores trabalham de forma mais eficaz quando são incentivados a identificar e avaliar os seus próprios problemas e propor melhorias, e quando colaboram para ajudar uns aos outros para se desenvolverem profissionalmente.

Greenwood e Levin (2006, p.102) caraterizam a pesquisa-ação do seguinte modo:

1) a pesquisa-ação é uma investigação na qual há uma co-produção de conhecimentos entre os participantes e os pesquisadores por meio de processos comunicativos colaborativos nos quais todas as contribuições dos participantes são levadas a sério. Os significados construídos no processo de investigação conduzem a ação social, ou ainda essas reflexões sobre a ação levam a construção de novos significados; 
2) a pesquisa-ação trata a diversidade de experiência e de capacidades dentro do grupo local como uma oportunidade para o enriquecimento do processo de pesquisa/ação;

3) a pesquisa-ação produz resultados válidos de pesquisa;

4) a pesquisa-ação concentra-se no contexto; seu objetivo é resolver problemas da vida real em seu contexto.

Esses autores destacam o papel da chamada investigação co-produtiva que consiste na cooperação entre o pesquisador e os colaboradores, os participantes da pesquisa. Esse é um ponto em que os autores se diferenciam da crença positivista de muitas cientistas sociais que demandam de um pesquisador para manter a distância para o que é suposto ser observado, o que, de acordo com os autores, "leva ao distanciamento da produção de informações confiáveis, de interpretações significativas e de ações sociais na pesquisa social" (GREENWOOD; LEVIN, 2006, p.102).

Reason e Breadbury (2001) enfatizam o conhecimento prático da pesquisa-ação em suas vidas diárias, dizendo que pesquisa-ação significa focar em resultados práticos e criar novas maneiras de compreensão, porque a ação sem essa compreensão é "cega", como a teoria sem ação não teria sentido. Segundo eles, a pesquisa-ação começa com a experiência cotidiana e o desenvolvimento do processo de conhecimento vivido, o processo próprio de investigação sendo tão importante quanto os resultados específicos.

Uma boa pesquisa-ação emerge ao longo do tempo em um processo evolutivo e de desenvolvimento, como habilidade de desenvolvimento individual de investigação e como coletividades de desenvolvimento de investigação no seio de comunidades práticas (REASON; BRADBURY, 2001). Cohen e Manion (1994, p.192) articulam a natureza emergente da pesquisa-ação, definindo-a como

[...] essencialmente um processo in situ projetado para lidar com um problema concreto localizado numa situação imediata. Isto significa que, idealmente, o processo passo-a-passo é constantemente monitorado por períodos variados de tempo e por uma variedade de mecanismos (questionários, diários, entrevistas e estudos de caso, por exemplo), de modo que o feedback que se segue pode ser traduzido em modificações, ajuste, mudanças direcionais, redefinições, se for necessário, de forma a trazer benefícios duradouros para o próprio processo em curso, em vez de alguma ocasião futura. ${ }^{29}$

\footnotetext{
${ }^{29}$ do original: [...] essentially an on-the-spot procedure designed to deal with a concrete problem located in an immediate situation. This means that ideally, the step-by-step process is constantly monitored over varying periods of time and by a variety of mechanisms (questionnaires, diaries, interviews and case studies, for example) so that the ensuing feedback may be translated into modifications, adjustment, directional changes, redefinitions, as necessary, so as to bring about lasting benefit to the ongoing process itself rather than to some future occasion.
} 
Para Hopkins (2002), a pesquisa-ação consiste em uma combinação de um ato substantivo com um processo de investigação, ou seja, a ação é disciplinada pela investigação, é uma tentativa pessoal de compreensão ao ser envolvida em um processo de melhoria e reforma.

Para MacIntyre (2000), a pesquisa-ação é uma investigação em que, como resultado de uma rigorosa autoavaliação da prática corrente, o pesquisador foca em um assunto ou problema a fim de investigá-lo. Com base em informações do contexto, das pessoas que estarão envolvidas e sobre o estado da arte, ele prepara e implementa uma ação que será avaliada em seguida, a fim de desenhar conclusões baseadas nos resultados. $\mathrm{O}$ autor destaca que a reflexão constante é essencial durante o processo de investigação, o que pode ser conseguido por meio do debate mútuo, ao repensar e avaliar constantemente o conselho tirado da literatura, a questão de pesquisa bem como todos os outros aspectos do plano de ação, o que, consequentemente, provoca um caráter cíclico do processo.

Kemmis e McTaggart (1988, p.562) definem a pesquisa-ação como

[...] investigação deliberada e orientada para a solução que é de propriedade de e conduzida por um grupo ou uma pessoa. Caracteriza-se por ciclos espirais de identificação do problema, coleta sistemática de dados, reflexão, análise, ação orientada por dados conduzida e, finalmente, redefinição do problema. A ligação dos termos action e research destaca as características essenciais deste método: experimentar idéias na prática como um meio de aumentar o conhecimento sobre e/ou melhorar o currículo, o ensino e a aprendizagem. ${ }^{30}$

Uma das características mais importantes dessa abordagem na relação entre os pesquisadores e os participantes da pesquisa, tornando-se parceiros no processo, é partilhar a responsabilidade de identificar problemas específicos e aplicação local, estratégias orientadas para a ação (DENZIN; LINCOLN, 1994). A pesquisa-ação tem como objetivo o autoaperfeiçoamento profissional, que pode ser alcançado por meio da colaboração focada, segundo Freebody (2003), os proponentes desse tipo de pesquisa têm a intenção de permitir aos professores serem mais deliberativos e responsáveis em seus esforços para mudar a prática educativa.

Esse ponto essencial, ou seja, mudar a prática e a pesquisa em educação, também é enfatizado por Grundy (1994), que aponta que pesquisa-ação desafia a separação de pesquisa

\footnotetext{
${ }^{30}$ do original: [...] deliberate, solution-oriented investigation that is group or personally owned and conducted. It is characterized by spiralling cycles of problem identification, systematic data collection, analysis, data-driven action taken, and, finally, problem redefinition. The linking of the terms "action" and "research" highlights the essential features of this method: trying out ideas in practice as a means of increasing knowledge about and/or improving curriculum, teaching and learning.
} 
da ação, a separação do pesquisador e dos pesquisados (enfatizando a reforma das práticas educativas de toda a escola como uma comunidade), suposições sobre o controle do conhecimento e sobre a natureza da reforma educacional.

El Andaloussi (2004, p.86) constata que

na pesquisa-ação, a pesquisa tem a função de diagnosticar uma situação, iniciar uma ação, acompanhá-la, observá-la, conferir-lhe sentido, avaliando-a e incitando-a a desencadear novas ações. A pesquisa permite analisar uma situação para trazer um auxílio, esclarecer o significado do comportamento dos diferentes parceiros e também reduzir as divergências entre os participantes para que alcancem objetivos comuns.

O mesmo autor (2004) relata que a pesquisa-ação é determinada pelo estilo de pesquisa que se opera nela, podendo ela ser, por um lado, 1) a operação programada pelos pesquisadores, por outro lado 2) a situação natural e espontânea, bem como 3) um conjunto de operações planejadas em comum entre atores e pesquisadores.

Parece prudente a opinião de Bataille (1987 apud EL ANDALOUSSI, 2004) que considera o primeiro estilo descrito por El Andaloussi apenas uma estratégia de pesquisa e o segundo uma estratégia de ação, enquanto só o terceiro estilo é uma verdadeira pesquisa-ação, na medida em que "o dispositivo "pesquisa-ação" se torna dispositivo complexo", por este meio facilitando combinações entre elementos independentes. Ainda segundo o mesmo autor (apud EL ANDALOUSSI, 2004, p.89)

[...] a questão fundemantal, em uma pesquisa-ação, é a do significado do hífen: ora um dos termos (pesquisa, ação) é instrumentalizado a serviço do outro, ora o hífen visa a compactar os dois termos, ou então ele tem o sentido de uma articulação entre os dois termos (o que supõe logicamente que ambos tenham uma existência distinta).

Denzin e Lincoln (2006, p.100) definem a pesquisa-ação como:

[...] a pesquisa em que a validade e o valor dos resultados de pesquisa são testados por meio de processos colaborativos de geração e de aplicação do conhecimento do pesquisador profissional como insider em projetos de mudança social que visam a aumentar a imparcialidade, o bem-estar e a autodeterminação. Para nós, a pesquisaação é a única forma de pesquisa social que representa adequadamente essa agenda. $\mathrm{Na}$ pesquisa-ação, os colaboradores comunitários ou organizacionais trabalham em conjunto com os pesquisadores profissionais na definição de objetivos, na elaboração de questões de pesquisa, no aprendizado das habilidades de pesquisa, na combinação entre o conhecimento e os esforços, na condução da pesquisa, na interpretação dos resultados e na aplicação do que é aprendido para a produção de uma mudança social positiva.

Enquanto outros autores estabelecem que a pesquisa-ação envolve fatores e princípios já mencionados, Hult e Lennung (1980) e McKernan (1991) serão aqui referências 
porque acrescentam alguns princípios-chave da pesquisa-ação, dos quais gostaria de destacar os mais relevantes:

- concentra-se nos problemas que são de interesse imediato para os praticantes;

- é formativa, de modo que a definição do problema, os objetivos e a metodologia podem alterar durante o processo de pesquisa-ação;

- é colaborativa e utiliza o feedback de dados em um processo cíclico;

- é eclética metodologicamente;

- implica a avaliação e reflexão;

- é dialógica e enfatiza o discurso.

Dessa forma, Hult e Lennung e Mc Kernan contemplam de forma mais abrangente a pesquisa que aqui desenvolvo, pois eles apresentam princípios bem identificados com os que proponho neste trabaho.

Vários autores (LIU, 1997; CARR; KEMMINS, 1983; KEMMINS; MCTAGGART, 1988; ELLIOT, 1973; BARBIER, 2002, apud CHIZZOTTI, 2006) têm apresentado modelos próprios de pesquisa-ação na área da educação, baseando o processo de investigação sobre vários aspectos e procedimentos, a fim de realizar a pesquisa. Entretanto, cada um desses modelos pode ser condensado em alguma das fases, resumidas nos seguintes passos:

1) definir o problema;

2) formular o problema;

3) implementar a ação;

4) executar a ação;

5) avaliar a ação;

6) dar continuidade à ação.

Adoto a opinião de Koshy (2005) que determina ser útil considerar vários modelos. Ao mesmo tempo ele chama atenção para a dependência excessiva de um determinado modelo, seja seguir as etapas ou ciclos de um determinado modelo de forma rígida, poderia afetar adversamente a única oportunidade oferecida pela natureza emergente e de flexibilidade, que são as principais características da pesquisa-ação.

A pesquisa relatada nesta dissertação é baseada no modelo de Kemmis e McTaggart (2000) que descrevem pesquisa-ação como pesquisa participativa que envolve uma espiral de espirais autorreflexivos que consiste em: 
1) planejar uma mudança;

2) agir e preservar o processo e as consequências da mudança;

3) refletir sobre esses processos, consequências e replanejamento;

4) agir e observar;

5) refletir;

6) e assim por diante.

\section{Figura 2 - A Espiral Pesquisa-ação}

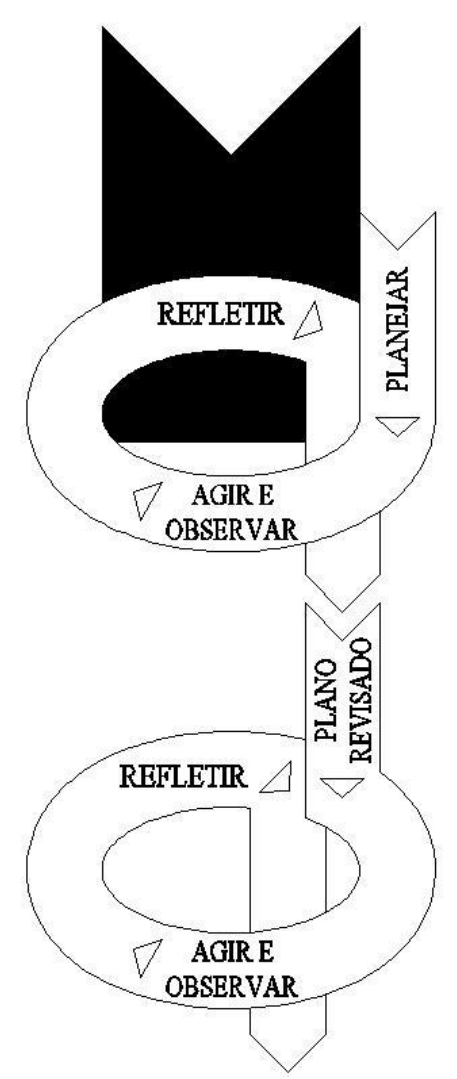

Fonte: Kemmis e McTaggart (2000 apud KOSHY, 2005)

A Espiral Pesquisa-ação (figura 2) proposta por esses dois autores consiste na seguinte sequência definida por Planejar, Agir e Observar e Refletir, o que se repete até a superação do problema ou mitigação dele até níveis aceitáveis. Essa síntese complementa os pontos mencionados acima. Contudo, os próprios autores recomendam que esse princípio seja aplicado de maneira flexível, ou seja, que essa estrutura de pesquisa-ação não deve ser rígida, mas sim flexível. Isso se baseia no fato de que, na realidade, os diferentes estágios podem 
sobrepor-se e não acontecer em momentos distintos, como é idealizado na ilustração 2: "Na realidade o processo provavelmente é mais fluido, aberto e reativo" 31 (KOSHY, 2005, p.5).

Dos vários modelos de pesquisa que existem, considero esse modelo o mais adequado para os meus propósitos, porque ele enfatiza fortemente o caráter reflexivoparticipativo da pesquisa-ação. Espero também que, devido ao seu caráter não-rígido e simplificado em que os participantes agem, possa-se desenvolver uma melhor compreensão geral do assunto e do contexto, capacitando-os a tomar as melhores ações possíveis, a fim de construírem seu próprio e melhor modelo possível de peer coaching, com base no atual contexto de suas realidades profissionais.

Depois de contemplar a pesquisa-acão como metodologia que é utilizada para conduzir o estudo aqui relatado, apresento o contexto em que esta pesquisa foi realizada.

\subsection{O Contexto da Pesquisa}

A pesquisa relatada neste texto foi realizada no Programa Permanente de Extensão UnB Idiomas, em Brasília, a antiga Escola de Línguas da Universidade de Brasília, onde já me tinha sido dada a possibilidade de fazer um estágio como professor de inglês.

O Programa Permanente de Extensão originou-se em 2008 a partir de uma iniciativa dos órgãos colegiados do Departamento de Letras (LET), do Instituto de Letras (IL) e do Decanato de Extensão (DEX) da Universidade de Brasília (UnB), garantindo uma nova concepção acadêmica para as atividades anteriormente desenvolvidas pela Escola de Línguas, possibilitando uma participação ativa do LET na realização das disciplinas de estágio supervisionado aos alunos dos cursos de Letras. ${ }^{32}$

Os cursos estão estruturados com o propósito de abrir programas sequenciais de idiomas, permitindo uma ampla gama de possibilidades de educação continuada para os alunos da universidade, mais especificamente, e para os alunos do Distrito Federal (DF), de modo mais abrangente. Atualmente, cerca de 15.000 alunos frequentam a UnB Idiomas por ano, com cursos oferecidos para 14 idiomas diferentes.

\footnotetext{
${ }^{31}$ do original: In reality the process is likely to be more fluid, open and responsive.

${ }^{32}$ Informações obtidas no site do UnB Idiomas. Disponível no link: 〈www.unbidiomas.unb.br〉
} 
A área de inglês dessa instituição emprega atualmente cerca de 70 professores para aproximadamente 5000 alunos, divididos em cerca de 200 grupos, em locais diferentes da cidade. Os cursos são oferecidos para todos os níveis (iniciante, intermediário, avançado), a oferta também inclui cursos especiais de inglês instrumental, conversação, aperfeiçoamento e cursos temáticos, só para citar alguns.

A pesquisa que dá suporte a este trabalho iniciou-se na UnB Idiomas pela apresentação dos conteúdos pretendidos e da sequência do projeto à supervisora da área de inglês. O próximo passo consistiu em enviar convites, por e-mail, para os potenciais participantes que tinham sido sugeridos pela supervisora, com base nos critérios mencionados anteriormente. O projeto era para ser realizado com duas duplas. Os quatro participantes que se voluntariaram foram então convidados para uma reunião inicial onde os princípios, os conteúdos e todas as outras informações com relação ao projeto foram apresentados por mim. Os participantes também aproveitaram essa oportunidade para fazer perguntas e dissipar suas dúvidas.

Durante essa reunião inicial, também ficou claro que o investimento de tempo que era esperado dos participantes ao longo do projeto não se limitaria às sessões semanais de coaching. Isto foi devido ao fato de que, com base na análise inicial ${ }^{33}$ dos pontos nos quais os participantes queriam trabalhar, os pares deveriam, em casa, pesquisar, por meio de leitura ou da internet, e elaborar atividades e apresentá-las para seus pares. Todos os participantes concordaram com essas demandas.

No entanto, depois de três semanas do início do projeto, um dos participantes decidiu desistir, por motivos pessoais. Apesar de muito esforço e muitos convites para outros professores da área de inglês, nenhum outro professor poderia ser encontrado para substituir o participante que tinha saído do projeto, portanto, apenas os dados da dupla que permaneceu foram utilizados para esta pesquisa.

\subsection{As Participantes da Pesquisa}

A seleção das professoras de inglês como participantes nesta pesquisa foi feita em cooperação com a supervisora da área de inglês da UnB Idiomas. Dos critérios para esta seleção, foi necessário que as participantes fossem do mesmo status profissional na instituição

\footnotetext{
${ }^{33} \mathrm{~A}$ análise inicial realizou-se por meio do coaching wheel, veja Apendice C.
} 
e motivadas para participar ativamente no projeto. Outro aspecto importante para realização de um projeto peer coaching precisou ser considerado: que as professoras pudessem trabalhar juntas, em duplas, pois necessitariam ter uma relação respeitosa e aberta uma com o outra, a fim de criar um ambiente confiante, que é essencial para o êxito da pesquisa, como já mencionado anteriormente.

Uma das professoras participantes é Maria. Ela tem 47 anos de idade e leciona inglês como LE há 25 anos, tanto para adultos quanto para adolescentes. Sua experiência inclui o ensino em diversas instituições no Brasil, bem como uma experiência profissional de dois anos no Senegal, África. Maria terminou sua formação inicial em Letras Portugues/Inglês em 1994 e, durante sua carreira, também completou cursos adicionais relacionados à proficiênca na língua inglesa bem como ensino de inglês. Durante o tempo em que esta pesquisa foi realizada, Maria dava aulas para 6 diferentes turmas de níveis diferentes de proficiência na UnB Idiomas, em diferentes localidades da instituição, com duas aulas semanais por turma.

A outra professora da pesquisa, Bárbara, tem 23 anos de idade e tem 6 anos de experiência profissional em diferentes escolas de línguas de Brasília, ensinando inglês como LE para adultos e crianças. No momento da implementação do projeto, a professora ainda não tinha terminado o curso da Licenciatura em Português/Inglês, no entanto, só faltava o estágio supervisionado. Durante a pesquisa, foram atribuídas à professora cinco turmas de níveis diferentes na UnB Idiomas e ela também dava aulas para algumas turmas em outras instituições e para alunos particulares.

\subsection{O Pesquisador}

Sou alemão, tenho 38 anos de idade, e tenho trabalhado como professor de inglês e alemão por vários anos e em diferentes países. Cheguei ao Brasil pela primeira vez em 2011 e decidi voltar em 2012 a fim de reiniciar minha vida acadêmica.

Como mencionado anteriormente, na pesquisa relatada nesta dissertação, acompanho o processo de peer coaching em suas diferentes etapas, oferecendo também apoio prático às participantes baseado na minha experiência como professor de línguas. Devido ao tempo limitado das participantes, que estavam ambas trabalhando muitas horas e em diferentes instituições, durante o andamento do projeto, também assumi outras responsabilidades, como por exemplo, recapitular as sessões de coaching por e-mail e manter a comunicação entre as 
participantes a fim de diminuir a carga de trabalho delas, estruturando o projeto e tornando mais fácil o controle das tarefas.

Tudo isso me colocou no papel de líder, consultor e também motivador, sempre tentando oferecer apoio quando fosse possível.

\subsection{A Coleta de Registros ${ }^{34}$}

Segundo Stringer (2007), a pesquisa-ação utiliza os dados qualitativos e quantitativos para ampliar e esclarecer a compreensão dos participantes em uma questão. Assim, Bogdan e Biklen (1998, p.106) atribuem uma grande importância à coleta dos registros que eles enfatizam da seguinte forma:

Os dados são tanto provas quanto pistas. Coletados cuidadosamente, eles servem
como fatos rígidos que dão suporte ao texto que você fará a partir de especulações
infundadas. Os dados lhe dão base no universo empírico e, quando coletados de
forma sistemática e com rigor, ligam a pesquisa qualitativa às outras formas de
ciência. Os dados envolvem detalhes que você precisa a fim de pensar
profundamente e minuciosamente sobre os aspectos da vida que você deseja
explorar. ${ }^{35}$

Considerando a natureza qualitativa da pesquisa relatada nesta dissertação, os instrumentos de coleta de dados são escolhidos tendo em vista a busca de respostas às perguntas da pesquisa.

Denzin e Lincoln (2006) constatam que, na pesquisa qualitativa, os pesquisadores usam uma grande variedade de métodos interpretativos associados, a fim de desenvolver a melhor compreensão possível do tópico. Eles comparam o pesquisador a um bricoleur, que é uma metáfora para designar pessoas com o perfil de "faça você mesmo", ou ainda, no contexto da produção de filmes, com alguém que reúne fotos, a fim de montar um filme. As unidades individuais devem finalmente resultar em uma descrição consistente do que foi encontrado, ilustrando a complexidade e profundidade do ocorrido:

O produto do trabalho do bricoleur interpretativo é uma bricolage complexa (que lembra uma colcha), uma colagem ou uma montagem reflexiva - um conjunto de

\footnotetext{
${ }^{34}$ Segundo Erickson (1986), os materiais brutos coletados são denominados "registros". Após passarem pelo processo de categorização, são nomeados como dados.

${ }^{35}$ do original: Data are both the evidence and the clues. Gathered carefully, they serve as the stubborn facts that save the writing you will do from unfounded speculation. Data ground you to the empirical world and, when systematically and rigorously collected, link qualitative research to other forms of science. Data involve the particulars you need to think soundly and deeply about the aspects of life you will explore.
} 
imagens e representações mutáveis, interligadas. Essa estrutura interpretativa é como uma colcha, um texto de performance, uma sequência de representações que ligam as partes ao todo (DENZIN; LINCOLN, 2006, p.20).

Koshy (2005) afirma que os pesquisadores devem estar conscientes das duas categorias de dados (respectivamente quantitativa e qualitativa) e considerar a sua utilidade no contexto de seu projeto de pesquisa. No entanto, é provável que um action-researcher (pesquisador-em-ação) usaria principalmente o paradigma qualitativo, no qual os dados podem surgir mais sob a forma de transcrições, descrições e documentos a serem analisados. De acordo com ele, os dados qualitativos na pesquisa-ação podem iluminar os sentimentos humanos e fornecer informações valiosas sobre ações e suas consequências.

Bogdan e Biklen (1998) explicam que os dados quantitativos podem ter um uso convencional na pesquisa qualitativa, o que seria o caso da utilização de informação estatística sobre os alunos, fornecida pelas escolas ou professores, por exemplo. Também pode fornecer informações descritivas (sobre idade, raça, sexo, status socioeconômico) e, consequentemente, abrir caminhos para explorar novas perspetivas.

\subsubsection{Os instrumentos de coleta de registros}

Nelson et al. (1992), constatam que as práticas da pesquisa deveriam ser escolhidas dependendo das perguntas que são feitas, as quais também dependem de seu próprio contexto. Tudo isso se baseia nas informações que são acessíveis e, no que o pesquisador pode elaborar, no contexto específico.

Segundo Finch (2005), um único instrumento de pesquisa pode produzir resultados enganosos se o peso excessivo é dado aos seus "achados". Em vez disso, ele aconselha utilizar uma série de instrumentos em paralelo para a investigação. Dessa forma, os resultados podem ser comparados e triangulados com maior confiança em suas implicações conjuntas. Esses instrumentos podem ser:

1) formas de avaliação em pares e autoavaliação;

2) questionários;

3) observação;

4) listas de verificação;

5) entrevistas; 
6) diário do professor; dentre outros.

Flick (1998) também considera a multiplicidade de métodos uma caraterística inerente à pesquisa qualitativa.

Nas seções seguintes serão descritos os instrumentos de coleta de registros que foram usados para o estudo aqui relatado.

\subsubsection{Questionário}

Koshy (2005) aponta que o uso de questionários no início de um projeto pode ser muito útil porque, muitas vezes, eles ajudam a coletar várias informações com relativa facilidade, as quais podem ser seguidas, se for necessário. Além disso, a análise de um questionário pode ajudar a desenvolver as questões que o pesquisador pode querer perguntar durante quaisquer entrevistas ou observações pessoais.

\subsubsection{Entrevistas semi-estruturadas}

Segundo Silveira (2002, p.120), entrevistas são "eventos discursivos complexos, forjados não só pela dupla entrevistador/entrevistado, mas, também, pelas imagens, representações expectativas que circulam - de parte a parte - no momento e situação de realização das mesmas e, posteriormente, de sua escuta e análise”.

Assim como Silveira (2002, p.122) reflete a ideia de Arfuch (1995) sobre a entrevista como gênero discursivo, abordando

[...] em primeiro lugar a situação comunicativa, regida pelo intercâmbio dialógico, seus participantes, sua vizinhança com a conversa cotidiana, os usos da linguagem, suas infrações, o que de previsível e de imprevisível tem esse jogo intersubjetivo da verdade (do coloquial ao formal, do chiste, do mal-entendido, da ironia ou da agressão).

As três entrevistas conduzidas (inicial, após a metade do tempo, final, ver Apêndices $\mathrm{H}$, I e J) na pesquisa que aqui relato, destinam-se a coletar registros descritivos nas próprias palavras das professoras, a fim de desenvolver alguns entendimentos sobre como elas interpretam aspectos determinados do mundo, como descrito por Bogdan e Biklen (1998). As perguntas das entrevistas do tipo semi-estruturadas foram desenvolvidas seguindo uma 
formulação flexível, a fim de permitir que as entrevistadas pudessem refletir sobre como expressar seus pensamentos, tendências e reflexões (ROSA; ARNOLDI, 2006).

Na pesquisa aqui relatada, o instrumento de coleta de gravação de áudio é usado para assegurar as entrevistas realizadas com as participantes. Isso tornou possível o acesso à informação recolhida a qualquer momento depois de gravada, a fim de permitir a análise das sessões posteriormente. As entrevistas foram transcritas por mim e serviram como fonte importante para a análise dos dados.

\subsubsection{Notas de campo}

Bogdan e Biklen (1998, p.107-108) definem notas de campo como "[...] relato escrito de que o investigador ouve, vê, experiencia e pensa no decurso da recolha e da reflexão sobre os dados de um estudo qualitativo". ${ }^{36}$

Os registros consistem em descrições de pessoas, objetos, lugares, eventos, atividades e conversas, assim como ideias pessoais, estratégias, reflexões, noções e padrões de notas que surgem durante o processo da pesquisa. As notas de campo também podem ajudar o pesquisador a manter o controle do desenvolvimento do projeto, a fim de visualizar como o plano de pesquisa foi afetado pelos dados coletados e de manter-se consciente de como ele foi influenciado por esses dados (BOGDAN; BIKLEN, 1998).

Ainda segundo os mesmos autores, outra função importante que as notas de campo exercem é que elas podem servir como um importante suplemento para entrevistas gravadas, ao liberarem os pesquisadores para registrar aspectos não verbais das entrevistas, as impressões e também as observações adicionais feitas antes e depois da entrevista. Outro aspecto é que elas podem fornecer um registro pessoal a qualquer estudo, o que possibilita ao pesquisador manter o controle do projeto e do plano de pesquisa. Assim, a redação das notas de campo tomadas segue as orientações apresentadas por Bogdan e Biklen (1998).

\footnotetext{
${ }^{36}$ do original [...] the written account of what the researcher hears, sees, experiences, and thinks in the course of collecting and reflecting on the data in a qualitative study.
} 


\subsubsection{O diário dialogado}

Os diários dialogados são documentos escritos de forma convencional (caderno) ou online. Os registros das atividades, chamadas de entradas, ocorrem de modo livre e sem obrigatoriedade, quando os participantes têm vontade de escrever, e ficam estimulados, quando o pesquisador sugere o registro, por exemplo, sobre um tópico específico (SABOTA, 2008 apud SABOTA, 2010).

Tápias-Oliveira (2005, p.167) usa o diário dialogado com alunos em processo de formação docente e recomenda-o como instrumento para efetuar a autopercepção e automonitoração deles que, por sua vez, possibilita identificar os pontos fortes (para aperfeiçoamento) bem como as dificuldades (para superação), considerando "o papel do diário como instrumento possibilitador da criação de um mundo figurado que permite a releitura de velhas práticas com novos olhos".

$\mathrm{Na}$ pesquisa aqui relatada, os diários foram escritos pelas participantes de forma online a fim de facilitar a troca entre elas e o pesquisador. Ao longo da pesquisa, as participantes fizeram a troca dos documentos duas vezes para que elas pudessem comentar o diário da parceira. Tais diários deram suporte às respostas das perguntas de pesquisa.

\subsection{Condução da pesquisa}

$\mathrm{Na}$ pesquisa aqui relatada, tenho a intenção de identificar as contribuições que a implementação de um projeto de peer coaching oferece às professoras de inglês em serviço, no contexto atual. Nesta seção, viso a esclarecer o contexto e os procedimentos que guiaram a dupla em peer coaching.

Realizei meu projeto no Programa Permanente de Extensão UnB Idiomas, situada na cidade de Brasília, onde, anteriormente, eu já havia tido a possibilidade de realizar um estágio como professor de inglês. A instituição oferece atualmente cursos de 14 línguas diferentes, atende cerca de 15 mil alunos por ano e é um dos centros de referência em ensino de línguas em Brasília. Por isso, entendi que na UnB Idiomas haveria um ambiente academicamente adequado para a implementação de um programa de peer coaching, uma vez que a maioria dos professores é formada em Letras e, portanto, tem formação inicial bem equiparada entre os pares. 
Após uma apresentação inicial à diretora dessa instituição sobre à implementação do peer coaching, foi assinado um Termo de Consentimento Livre e Esclarecido pela coordenadora geral (vide Apêndices A e B). Da mesma forma, ambas as professoras assinaram um Termo de Consentimento Livre e Esclarecido a fim de autorizar o uso dos registros resultantes da pesquisa (vide Apêndices C e D). As participantes da pesquisa tiveram suas identidades protegidas por pseudônimos, por princípios éticos.

Para o projeto, as duas professoras trabalharam juntas com o pesquisador (Bernd Renner) ao longo de um período de três meses. A chamada coaching wheel ${ }^{37}$ (roda de coaching) foi usada no início da pesquisa relatada nesta dissertação, a fim de definir os temas que as participantes queriam trabalhar. Cada participante preencheu sua própria roda de coaching, junto com seu par. As rodas serviram como ponto de partida para as atividades desenvolvidas que focaram na melhoria dos pontos específicos de ensino que tinham sido identificados, durante os próximos encontros.

Em sua roda de coaching inicial, Bárbara marcou os seguintes tópicos que queria trabalhar: atividades na sala de aula, prática da fala fora de sala de aula, correção de erros, literatura e cultura, tempo de fala dos alunos, autoavaliação do professor, planejamento de aulas e motivação/participação dos alunos. Ela considerou seu nível atual de satisfação, em relação a esses tópicos individuais, com valores entre 2 e 4, numa escala de 1 (baixo) a 10 (alto).

Comparativamente, Maria marcou os seguintes tópicos na sua roda de coaching: melhoria da fala dos alunos, pronúncia de palavras e frases difíceis, oportunidades da fala fora de sala de aula e melhoria de escrita dentro e fora de sala de aula. Ela considerou seu nível de satisfação, em relação a esses tópicos, com valores entre 4 e 8.

As reuniões semanais, ao longo de um período de 3 meses, ocorreram semanalmente todas às sextas-feiras, e foram iniciadas pelas reflexões e discussões subsequentes das participantes sobre experiências ou medidas específicas que tinham sido testadas por elas em sala de aula. Posteriormente, foram apresentadas, pelas participantes e também pelo pesquisador, novas atividades e sugestões para serem discutidas no grupo. Essas tinham sido

\footnotetext{
${ }^{37}$ A roda de coaching (GORNALL; BURN, 2013) é uma ferramenta que foi utilizada para definir e analisar os temas que as participantes trabalharam, ao longo da pesquisa (vide Apêndice E).
} 
elaboradas autonomanente pelos membros do grupo, antes das chamadas sessões de coaching semanais.

Ao fazer isto, elas ficaram livres para usar quaisquer recursos para preparar suas atividades, sejam esses literatura específica, experiências próprias ou também atividades para sala de aula encontradas na internet, por exemplo. Dessa forma, as professoras, junto com o pesquisador, focarem-se em questões determinadas inicialmente pelas participantes e, assim, trabalharam na melhoria das questões individuais.

As atividades adicionais que foram realizadas fora dos encontros regulares incluíram, por exemplo, observações em sala de aula, uma palestra em outra instituição de ensino bem como a escrita do diário dialogado mencionado anteriormente.

A observação em sala de aula supracitada deveria seguir certos critérios descritos por Gottesman (2000): o inviting teacher (o professor anfitrião) convida seu par (e o pesquisador) para observarem uma de suas aulas. Na pré-observação, o professor anfitrião define os parâmetros para a observação (isto é: hora, duração, dentre outros aspectos) e comunica os pontos em que ele quer ser observado pelo par que, durante a observação, atua como "câmera", observando os pontos correspondentes, a fim de tomar notas.

Durante a pós-observação, o par relata para o professor anfitrião suas descobertas. Essa última parte, supõe-se, deve ser realizada sob o princípio chamado no praise, no blame (sem elogio, sem acusação). Isso significa que o par não pode criticar a aula nem o professor anfitrião, nem de forma positiva nem negativa, quando relatar suas observações. Essa forma de realizar feedback sem qualquer julgamento deveria, segundo Gottesman (2000), ajudar a evitar de o professor anfitrião sentir-se criticado pessoalmente, o que poderia impedir o processo de peer coaching.

\subsection{A Análise de Dados}

Bogdan e Biklen (1998, p.106) comparam a busca de informações no processo de investigação do pesquisador com o trabalho de um mineiro que apanha pedras na busca de ouro. Assim, os dados coletados assumem importância ao serem abordados por uma estrutura de pensamento específica, que é a do pesquisador. Segundo os mesmos autores há uma grande variedade de diferentes estilos de pesquisa qualitativa e muitas formas de manipulação e de 
análise de dados. Esses autores (1998, p.157) descrevem a análise da seguinte forma:

A análise de dados é o processo de busca sistemática e organização das transcrições de entrevistas, das notas de campo e de outros materiais, que você acumula a fim de aumentar o seu próprio entendimento deles, e, também, de permitir-lhe apresentar para as outras pessoas o que você descobriu. A análise envolve trabalhar com dados, organizá-los, quebrando-os em unidades manejáveis, sintetizá-los, em busca de padrões, descobrir o que é importante e o que deve ser aprendido, e decidir o que você vai dizer para as outras pessoas. ${ }^{38}$

No contexto da pesquisa-ação, há vários autores que recomendam a técnica de triangulação para analisar os dados oriundos da pesquisa, após coleta por meio dos intrumentos descritos e justificados anteriormente: Creswell (2008), por exemplo, descreve a triangulação como um processo de corroboração de evidências de diferentes indivíduos, tipos de dados e métodos de dados, tendo como finalidade aumentar o rigor e a credibilidade da pesquisa com base em múltiplos pontos de vista.

Gorad e Taylor (2004) também recomendam a triangulação especificamente para pesquisa-ação, a fim de aumentar a validade da pesquisa. Comparados com que diz Creswell (2008), eles dão um passo adiante em sua definição mais complexa, ao afirmar que uma sinergia adicional vem do espaço triangular criado pela combinação de três pontos de vista.

No entanto, há outros autores como, por exemplo, Richardson (1994) que desafiam esse conceito de triangulação, considerando-o não suficiente. Ela explica que a pesquisa qualitativa deve ser sujeita à imagem de cristal:

[...] os cristais crescem, mudam, alteram-se [...] Cristais são prismas que refletem externalidades e refratam-se dentro si mesmos, criando diferentes cores, padrões, exibicões, que se lançam em diferentes direções (RICHARDSON, 1994, p.522).

A cristalização descrita anteriormente manifesta seu efeito na aplicação simultânea de métodos diversos, resultando numa imagem multidimensional e multifaceada de um só e mesmo fenômeno. A meu ver, uma pesquisa qualitativa deve basear-se em uma variedade de instrumentos e refletir vários aspectos, com o intuito de garantir uma compreensão mais profunda de um fenômeno. Portanto, adoto o que Richardson chama de conceito de cristalização, que é uma forma estendida da triangulação "plana".

\footnotetext{
38 do original: Data analysis is the process of systematically searching and arranging the interview transcripts, field notes, and other materials that you accumulate to increase your own understanding of them and to enable you to present what you have discovered to others. Analysis involves working with data, organizing them, breaking them into manageable units, synthesizing them, searching for patterns, discovering what is important and what is to be learned, and deciding what you will tell others.
} 
De acordo com Bogdan e Biklen (1998), há duas formas de análise de dados: a primeira consiste em analisá-los simultaneamente com o processo de coleta de registros, enquanto a segunda sugere que todos os registros têm de ser recolhidos antes do início do processo da análise. Na pesquisa aqui relatada, adoto a primeira modalidade de análise.

Assim, o próprio processo de análise de dados da pesquisa aqui relatada segue as orientações de Bogdan e Biklen (1998), que fornecem uma orientação estruturada para fazer da análise uma parte corrente da coleta de dados, ao mesmo tempo em que preparam o pesquisador para fazer uma análise final. Os autores sugerem o estabelecimento de certas categorias de dados, apontando, ao mesmo tempo, que a análise não se baseia apenas neles, mas também nas perspectivas e nos valores sociais que os investigadores possuem e que, portanto, influenciam a maneira como eles se aproximam e dão sentido aos dados. Assim, é o pesquisador, em última instância, que decide quais processos, atividades, eventos ou perspectivas ocorrentes da pesquisa tornam-se categorias.

Assim, os autores (1998) recomendam as seguintes etapas para começar a trabalhar com os dados:

1. Desenvolver uma lista preliminar com categorias; anotar novos códigos, ideias ou diagramas que eventualmente surjam durante a leitura por meio dos dados;

2. Atribuir esses códigos às unidades de dados (ou seja, pedaços de notas de campo, transcrições ou outros documentos) a fim de comprovar se as categorias existentes forem úteis. Se necessário, estas podem ser modificadas (antigas podem ser descartadas, novas podem ser desenvolvidas);

3. Estabelecer uma lista limitada de códigos (entre 30-50), experimentando com diferentes possibilidades de codificação, criar uma nova lista e assim por diante;

4. Reformular a lista novamente e, se necessário, limitar o número de códigos principais;

5. Desenvolver níveis diferentes de códigos: códigos principais (mais gerais, incorporando uma ampla gama de atividades, atitudes, comportamentos etc.) e, posteriormente, dividi-los em subcódigos a fim de avançar a análise ainda mais. 
$\mathrm{Na}$ pesquisa aqui relatada elegi como categorias de dados Revelações, Coaching, Peer Coaching, Relações e Motivação e, por final, Avaliação das Atividades do Peer coaching/Entrevistas ao longo do Projeto.

Este capítulo visou apresentar a metodologia empregada na pesquisa relatada nesta dissertação, descrevendo os princípios da pesquisa-ação, o contexto, as participantes e o pesquisador, a coleta de registros e o procedimento de análise de dados. Na capítulo seguinte, apresento e analiso os dados obtidos sobre peer coaching com professoras da UnB Idiomas, na Universidade de Brasília, Brasil - DF. 


\section{APRESENTAÇÃO E ANÁLISE DE DADOS}

A análise que se segue ocorre à luz dos princípios da pesquisa-ação e dos fundamentos teóricos e metodológicos abordados nos capítulos anteriores.

Os instrumentos de coleta de registros foram um questionário, entrevistas semiestruturadas realizadas com as professoras, as notas de campo do pesquisador e um diário dialogado escrito pelas participantes. Após concluir o projeto de peer coaching na UnB Idiomas, iniciei a transcrição das entrevistas, o que foi seguido por uma revisão cuidadosa de todos os documentos usados, a categorização dos registros e a subsequente análise de dados.

Com isso, pretendo evidenciar o processo formativo de peer coaching como proposta alternativa para a formação continuada de professores de inglês em serviço no Brasil.

\subsection{Revelações}

4.1.1 Motivação Inicial em Relação à Participação no Projeto e às Expectativas dos Participantes

Coloco as expectativas das participantes e suas motivações iniciais em relação à pesquisa no início da minha análise de dados, pois mostram os motivos individuais para a participação voluntária das duas professoras na investigação.

Questionada sobre a motivação para sua participação, Maria articula seu desejo de interagir e trocar experiências com outros colegas, ao mesmo tempo em que considera o projeto um desafio instigante à sua rotina, como mostra o excerto da primeira entrevista feita no dia 22/08/2014:

Minha motivação era trocar materiais de ensino, informações e ideias. Eu precisava
disso, eu sentia que estava trabalhando por mim o tempo todo, e queria algo que me
exigisse mais de mim mesma. Foi por isso que entrei. Eu preciso falar com as
pessoas, ouvir mais as pessoas, as coisas para as quais não temos tempo, porque nós
estamos muito ocupados, e se tiver algo mais sério, mais disciplinado, é mais
interessante, é por isso que estou me forçando nisso. Eu preciso disso, às vezes
precisamos sentir pressionados, pelo tempo, por algumas regras, pela autoridade,
porque se fosse por mim, por causa do tempo, provavelmente eu não me agendaria
para vir para cá e falar com você, acho que não.

A partir desse excerto, reconheço o desejo de Maria de superar o isolamento que sente em sua vida profissional. No entanto, parece interessante que, como voluntária, percebe o fator pressão como motivação adicional para participar do projeto, sugerindo que, sem a relativa obrigação, ela provavelmente não teria participado. 
Em outro excerto do dia 22/08/2014, ela é questionada sobre suas expectativas indicando novas inspirações para avançar profissionalmente: "Eu preciso de ideias diferentes de outras pessoas. Eu não sei quando vou me aposentar, mas até então eu preciso melhorar, eu não quero estar estagnada, eu não quero ficar parada no tempo com meu ensino".

Em outro momento, no entanto, ela se mostra cética sobre sua participação no projeto. Inicialmente, diz hesitar, mas, por fim, acaba por ceder e entrar no projeto, segundo se observa no excerto do diário dialogado do dia 31/08/2014: "No início, aceitei a ideia com relutância [...] Mas, depois de pensar melhor, achei que seria positiva. Eu me sinto como compartilhar minhas experiências de sala de aula com outra pessoa".

No caso da outra professora, Bárbara, parece que ela esteve realmente animada para participar da pesquisa, como reflete o excerto de seu diário dialogado do dia 22/08/2014: “Aceitaram-me para fazer parte da equipe! Finalmente estou prestes a participar de algo realmente maravilhoso: uma pesquisa sobre uma nova maneira de treinar professores, isto é peer coaching!’.

$\mathrm{Na}$ entrevista inicial do dia 22/08/2014, ela também afirma que, em sua vida profissional, ela nunca teve a chance de participar de uma iniciativa semelhante:

Bem, a minha motivação é a equipe que terei. Eu acho que isso é importante. Eu nunca trabalhei numa escola com pessoas que realmente queriam melhorar, que realmente queriam ser professores para sempre. [...] Mas aqui, sim, temos pessoas que realmente querem ser professores, e isso realmente me motiva a tentar melhorar mais a cada dia [...] e as minhas expectativas são as melhores possíveis, eu quero aprender com os meus amigos mais experientes, não sei eu não quero ter todas as respostas para as minhas perguntas, mas quero ter sempre essa energia para procurálas. É isso.

O excerto anterior também reflete que Bárbara, com pouca experiência na profissão, estava ansiosa para colaborar com outros professores que seguem a mesma meta que ela, que é de crescer profissionalmente, esperando se beneficiar das experiências deles. As palavras dela mostram que não espera encontrar soluções para todos os seus problemas, mas espera inspirar-se, a fim de ser capaz de ajudar a si mesma, em sua futura vida profissional como professora.

Apesar de ambas parecerem compartilhar o mesmo desejo de trabalhar numa equipe de colegas, acredito que Maria manifesta um desejo de trocar experiências com colegas, dispondo-se a assumir um papel ativo no processo, enquanto Bárbara coloca-se como aprendiz, na ânsia de aprender com os colegas mais experientes. 
Sem tentar definir com exatidão suas expetativas, a motivação geral por parte de Bárbara parece ser maior. Maria, por sua vez, decidiu participar apenas após alguma consideração, motivada pela chance de obter novas inspirações para superar certa estagnação percebida em sua vida profissional.

\subsubsection{As primeiras impressões do pesquisador}

Coloco também os meus próprios pontos de vista como pesquisador no início deste capítulo, a fim de dar uma melhor ideia sobre minhas expectativas e preocupações acerca do projeto, uma vez que se trata de uma pesquisa-ação:

[...] Eu estava e ainda estou preocupado com o projeto, especialmente sobre como manter a motivação das participantes durante os próximos 3 meses [...] A minha pesquisa-ação é um projeto piloto, estou tentando aplicar um projeto de peer coaching numa instituição que não tem, até agora, nenhum coaching em vigor. Uma preocupação adicional é o fato de que sou estrangeiro neste país. Não são apenas a comida e o tempo que são diferentes aqui, a mentalidade das pessoas, suas atitudes, suas crenças, por que elas fazem o que fazem, especialmente agora no contexto de ensino (de inglês), tudo é diferente. Acho que preciso ser muito cuidadoso no meu enfoque, em como me comunicar com as participantes, considerando o tempo limitado das professoras, ao mesmo tempo mantendo o meu foco e as atividades suficientes para avançar com o meu projeto.

O excerto das minhas notas de campo, realizado no dia 18/08/2014, após encontrar as participantes da pesquisa pela primeira vez, mostra minha preocupação no que diz respeito ao êxito do projeto e, principalmente, a apresentação deste às participantes.

No entanto, como outro excerto de minhas notas de campo do mesmo dia (18/08/2014) mostra, eu também estava mais otimista em relação a um percurso positivo do projeto, esperando obter bons resultados:

Minha primeira impressão foi muito boa. Antes e depois da minha apresentação, todos mostraram interesse no projeto, também fazendo perguntas sobre mim e minha motivação para fazê-lo. Antes da apresentação real, tivemos uma primeira conversa interessante sobre a vida de professores de inglês, sobre a UnB Idiomas etc. [...] Em suma, eu me sinto mais confiante agora, esperando realizar um bom projeto com resultados significativos.

\subsubsection{Formação de professores no Brasil}

Esta parte da minha análise trata das experiências existentes das participantes durante a formação inicial e continuada em suas vidas profissonais. O projeto de peer coaching na pesquisa relatada neste texto propõe-se como alternativa de processo formativo no contexto 
da formação continuada de professores. Considero importante ilustrar esses dados que fornecem informações sobre os conteúdos dos cursos e as percepções dos participantes durante o tempo que servem como base para esse projeto e a avaliação final dele pelas participantes.

\subsection{3a Formação inicial das professoras}

Maria fez o curso de Letras - Licenciatura em Português/Inglês na Universidade Federal de Goiás, Goiânia, entre 1990 e 1994. Na época, era chamado "Habilitação em Português e Inglês". Devido à sua proficiência em inglês e experiência em sala de aula preexistente, ela não tinha que frequentar os cursos de Língua Inglesa como parte do curso. Ela completou o estágio supervisionado no Colégio de Aplicação da UFG, Goiânia.

Questionada sobre a Licenciatura em Inglês que fez, ela confirma que considera os conteúdos das disciplinas atualizados para a época, como mostra um excerto da primeira entrevista do dia 22/08/2014:

Para a época, em 1990, eram atualizados, quando eu comecei eu aprendi muito, de Piaget, Chomsky, eu tinha que aprender tudo. Eu comprei os livros, eu li muito, Jeremy Harmer, todas essas pessoas. Penny Ur, li todos os livros dela.

Ela também considera o período do estágio supervisionado bastante positivo, o que se reflete no seguinte excerto da primeira entrevista do dia 22/08/2014:

Eu pude trocar experiências com o professor, que era o tutor na minha classe, e os
meus colegas, porque nós tivemos que trabalhar em pares. Por isso, tivemos de
observar uns aos outros. Sentei, e a minha parceira foi para o quadro e começou a
ensinar por 20 ou 30 minutos na sala de aula real. E depois nós trocamos: Eu fui
para o quadro, e ela me observou, juntamente com o professor, o verdadeiro
professor, o nosso tutor. Acho que foi muito interessante, muito avançado para a
época, você sabe, em Goiânia, eu tinha um treinamento muito bom. [...] Lembro-me
que eu tinha um problema, eu não gostava muito de ensinar crianças, pré-
adolescentes, entre 8 e 10 anos de idade, e eu tive essa experiência, na época, eu tive
que ensinar o curso do $5^{\circ}$ ano, e foi muito interessante, porque os alunos [...]
reagiram positivamente ao meu ensino, e eu nem sabia que seria assim.

As palavras de Maria, como mostra o excerto acima do dia 22/08/2014, indicam que ela percebeu o estágio supervisionado como uma atividade bastante útil, porque lhe deu possibilidades de trocar experiências com os colegas, de conseguir resolver problemas específicos, conforme o relato de ensino às crianças e pré-adolescentes. 
Outro excerto da primeira entrevista ilustra que ela entende o curso de Letras e seus conteúdos como um acréscimo de experiência como professora de inglês, como é o caso dos estudos de psicologia:

Quando eu tinha terminado a universidade, eu tinha sido treinada por algum tempo, você sabe. Não era uma coisa totalmente nova para mim. Então, eu me senti confiante. Então, você sabe, a universidade adicionou mais informações, por exemplo, em termos de psicologia.

Por sua vez, Bárbara começou Licenciatura em Português como Segunda Língua em 2008, e Licenciatura em Língua Inglesa em 2013, ambos na Universidade de Brasília e, no momento do projeto, ainda não tinha completado todas as disciplinas obrigatórias do curso de Letras Inglês. De acordo com suas informações, seu estágio supervisionado será encurtado, devido à sua experiência como professora de inglês. Questionada sobre sua opinião em relação aos conteúdos do curso de Letras Inglês, ela relata o seguinte no excerto da primeira entrevista do dia 22/08/2014:

Sim, eu acho que é um bom currículo, e como já me formei em português como Segunda Língua eu tinha muita teoria de como ensinar o português, e aplico algumas dessas teorias no inglês também, e acho que temos um currículo completo. Claro, precisamos de mais espaço para a prática, porque, quando saímos da universidade, nós não estamos completamente preparados para a sala de aula, e talvez mais disciplinas que foquem problemas interculturais, que é um assunto que temos em Letras Português [...], seria bom em Letras Inglês também.

Embora sua avaliação do currículo do curso de Letras seja verificada como positiva em geral, ela critica a falta de prática do curso. Isto, segundo ela, daria melhor preparo para o futuro professor. Isso, como ela sugere, poderia ser realizado por meio de assuntos adicionais, conforme se observa no excerto da primeira entrevista do dia 22/08/2014:

Alguns assuntos são atualizados, outros não. Eu acho que a maioria dos meus professores são jovens, e eles tentam ser o mais atualizados possíveis. Mas temos outros professores que gostam de ensinar ao "estilo antigo", da forma mais tradicional. [...] É claro que há coisas antigas que são sempre inovadoras.

Como as palavras acima demonstram, ela considera os conteúdos ensinados no curso de Letras, em grande parte, atualizados, considerando também que alguns temas são atemporais e, por isso, aplicáveis permanentemente.

\subsection{3b Formação continuada}

Além do projeto atual, Maria não participa em quaisquer outras atividades no contexto de formação continuada. Ela afirma, todavia, que chegou a participar no passado, de 
alguns seminários oferecidos por diferentes instituições, segundo afirma no excerto da primeira entrevista do dia 22/08/2014:

Há essa coisa BRAZ/TESOL, uma organização. Isto é muito bom, e você pode realmente participar. A última foi na Casa Thomas Jefferson, geralmente eu vou a esta escola. A Casa Thomas Jefferson é a escola top aqui no Distrito Federal. É uma coisa original, e, geralmente, a cada ano, eles convidam o público, durante as férias, para participar em eventos. [...] Eles geralmente têm um tema geral, "Ensinar em um mundo globalizado", ou algo parecido. Assistimos diferentes palestras, e vamos para salas diferentes ou escolhemos um seminário interessante, uma apresentação, e participamos. Não é tão difícil. [...] Além disso, eu só falo com outros professores, informalmente.

Bárbara relata que, durante seus estudos, ela participou de um projeto em que, como resultado, teve que desenvolver um trabalho acadêmico sobre o assunto. No entanto, devido à carga de trabalho profissional que ela está enfrentando, não tem tido condições de participar de qualquer atividade extra, como mostra o excerto da primeira entrevista do dia 22/08/2014:

Eu participava, acho que quando estava no meu quarto semestre, de um projeto de literatura sobre "comunicação escrita popular" [...] mas foi há muito tempo, e desde então eu comecei a trabalhar e, com certeza, perdi por não fazer parte de grupos de estudo, desde então eu nunca fiz parte de outras atividades.

Conforme os excertos anteriores demonstram, tanto Maria quanto Bárbara têm participado de poucas atividades de formação continuada em suas vidas profissionais. Maria, no passado, parece ter gostado de eventos que ofereceram possibilidades de diálogo para trocar experiências. Bárbara só participou de um projeto no qual teve que desenvolver um trabalho acadêmico, no entanto, expressa seu pesar por não poder participar, atualmente, de outras atividades, devido à sua carga de trabalho profissional.

\subsection{3c Percepção da situação atual dos professores no Brasil}

A formação inicial e continuada parece ser um problema real ao longo da vida profissional de um professor de línguas. Tentarei analisar como as participantes percebem sua situação profissional e as condições dos professores de línguas no Brasil. Em muitos excertos, as participantes do projeto colocam suas opiniões acerca dessa problemática. Das muitas afirmações coletadas, exponho algumas.

Num excerto do diário dialogado, do dia 31/08/2014, Maria menciona o baixo salário dos professores no Brasil, que foi comentado e confirmado posteriormente por Bárbara, seguido entre parênteses: 
É difícil dizer que somos professores bem-sucedidos e felizes no Brasil, porque os nossos salários são muito baixos. Eu acho que nós não estamos muito motivados.

(nunca devemos desistir de ter esperança [...] um dia as coisas vão mudar, eu acredito nisso e você também, eu sei).

Maria considera o baixo salário uma razão para a insatisfação e a baixa motivação dos professores no Brasil. Bárbara confirma o contexto situacional em seu comentário. Outro excerto das minhas próprias notas de campo (01/11/2014) ilustra outra questão que foi levantada por Maria, durante uma de nossas sessões de coaching:

Uma afirmação de Maria realmente me surpreendeu hoje. Eu tinha enviado para
Bárbara e para ela, por email, um convite para um curso com duração de 5 semanas
chamado "reflexão na ação", organizado pelo departamento de Letras da
Universidade de Brasília, que ocorreria às quintas à tarde. Maria disse que ela
"quase ficou com raiva" quando eu propus integrá-la ao curso, dizendo: "como você
poderia supor que temos tempo numa tarde de quinta-feira - somos professoras!".
Ela apontou para o fato de que, em relação à situação dela e da Bárbara, não é
possível se ausentar, porque não há professores suplentes que possam substituir
outros professores, e que apenas em casos de necessidade comprovada é que um
professor realmente pode procurar um substituto e pagá-lo para que ele o substitua
em sala de aula. Tanto Maria como Bárbara estavam interessadas no curso sobre
pronúncia, mas estavam impossibilitadas de participar.

$\mathrm{O}$ excerto mostra as dificuldades que Maria relata para participar em atividades no contexto de formação continuada. É importante esclarecer que Maria e Bárbara trabalham em outras instituições e com horários irregulares diferentes.

Maria aborda outro ponto, quando ela menciona a falta de valorização que os professores no Brasil enfrentam, que se reflete no excerto da segunda entrevista do dia 24/10/2014: "Eu tenho certeza sobre o que eu estou falando, o Brasil tem um problema cultural com a educação, com a valorização dos seus profissionais".

\subsection{3d A reflexão crítica (no início/ao longo do projeto)}

A parte seguinte trata da autorreflexão crítica das duas participantes na sua vida profissional e ilustra como essa reflexão desenvolveu ao longo desse projeto, sob a influência das atividades conduzidas do peer coaching. Considerando o fato de que este é um projeto piloto que se baseia numa pesquisa-ação, também relato minhas próprias reflexões como pesquisador, a fim de ilustrar as contribuições ao longo do percurso da pesquisa. 


\section{- Maria}

A pergunta a Maria, se ela se considera autocrítica em relação à sua prática profissional é fundamental para se compreender algumas contribuições do peer coaching na evolução profissional de sua vida como professora, conforme se observa no excerto da transcrição da primeira entrevista do dia 22/08/2014:

Eu sou. Eu sou mais crítica comigo agora do que antes. Mas eu sei que tenho que ser. Estou mais confiante, claro. Dou aulas há mais de 25 anos. Eu comecei em 1989, mas eu sei que estou mais crítica, porque eu quero fazer as coisas melhor, você sabe. Estou tentando me corrigir, eu cometo erros e às vezes faço anotações. Eu costumo fazer anotações, mas poderia ter feito isso melhor: como eu posso fazer meus alunos falarem mais, como posso maximizar as oportunidades de falar. [...] E é isso basicamente, eu tenho que ser mais paciente comigo mesma, eu sei disso. Eu tenho que ver as reações das pessoas.

Segundo a participante, a partir dessa reflexão permanente, ela consegue identificar os pontos que ela precisa melhorar. Além disso, essa reflexão, como ela confirma na mesma entrevista, acontece não só sob a forma de autorreflexão, mas também por meio da troca de experiências com outros professores, o que se reflete no seguinte excerto da primeira entrevista do dia 22/08/2014:

Sim, quando eu tenho a chance, eu faço, quando eu tenho a chance. Eu gosto de ouvir as pessoas. E quando eu estou feliz com a situação: "Eu usei esta técnica, eu usei esta experiência", e troco isso com outra pessoa. [...] "Olha, eu já tive essa experiência muito boa", e fiz coisas interessantes, algo que surgia do nada, que nunca tinha feito antes, é muito bom quando eu tenho a chance, mas nem sempre tenho.

De acordo com a participante, ela reflete regularmente sobre sua prática em sala de aula. No entanto, reconheço que a autorreflexão, que, segundo Maria, aumentou durante a sua vida profissional, parece ser uma parte integrante da sua vida diária, enquanto a reflexão com outros profissionais é algo que acontece apenas ocasionalmente, o que, para mim, é evidenciado na repetição da expressão "quando eu tenho a chance". Reconheço também, a partir do excerto, que Maria prefere trocar apenas experiências positivas.

No que diz respeito à reflexão durante o projeto atual, um excerto do diário dialogado de Maria, do dia 12/09/2014, revela que, durante uma sessão de coaching, ela se inspirou e ficou consciente de outros tópicos que ela queria melhorar no seu próprio ensino:

Fiquei feliz em dar uma olhada na roda de coaching de Diana ${ }^{39}$. Ela escreveu que uma de suas ideias era ver seus alunos se sentirem felizes, quando eram corrigidos. Esta é uma ideia muito boa em uma área na qual nós nunca temos certeza sobre algo.

${ }^{39}$ Diana e Thomas (pseudônimos) são participantes da segunda dupla que, depois de uma participação de 3 semanas, foi desfeita. 
Eu também olhei para a roda de coaching, do Thomas [...] Eu gostei do assunto "gestão do tempo". Eu percebi que eu tenho esse problema também. Eu tenho que trabalhar isso.

Segundo esses excertos acima, a aplicação do peer coaching resultou em um aumento da conscientização da prática, como sugere Freitas (2009). Isso, por sua vez, resultou no fato de que a participante se tornou ainda mais reflexiva e crítica, percebendo a necessidade de identificar e melhorar outras áreas na sua vida profissional como professora.

\section{- Bárbara}

Similarmente ao que Maria disse, quando perguntada inicialmente se ela se considerava reflexiva em relação à sua prática docente, Bárbara também confirma que a reflexão nem sempre foi parte de sua vida profissional, conforme se demonstra na primeira entrevista do dia 22/08/2014:

Eu me tornei reflexiva. (+++) No início eu não era. (++) Eu nunca me preparei
muito bem para uma aula, e realmente aprecio quem faz isso, professores que, eu
não sei, demoram um mês ou uma semana inteira para preparar material, e eu sei que
eu tenho essa falha, eu tenho que fazê-lo com mais frequência, e isso é algo que eu
tento aprender com meus amigos que também são professores, e eles são bons
exemplos.

Nesse excerto, ela registra que ela já desenvolveu certo nível de autorreflexão durante sua vida profissional. Reconheço, da hesitação na reflexão dela, um momento de conscientização sobre a necessidade de aprofundar este processo, com a ajuda de outros professores. Nesse contexto, ela cita um workshop do qual ela participou junto com uma amiga professora, segundo se observa no excerto da primeira entrevista do dia 22/08/2014:

Sim, tivemos um seminário aqui, nos dois últimos sábados de agosto. Sim, e eu
realmente acho que devemos ter mais workshops como esse, havia muitos
professores com as mesmas dúvidas, com diferentes problemas e outras questôes, e
nós realmente trocamos experiências. Eu tenho uma boa amiga que é professora de
espanhol, às vezes eu pergunto para ela: "como você lida com esse comportamento,
ou esse tipo de problema", e eu tento obter ideias.

Em contraste com Maria, reconheço o desejo de Bárbara em buscar ativamente possibilidades de trocar experiências com colegas, pedindo conselhos ao enfrentar questões ou problemas específicos.

A constante autorreflexão de Bárbara pode ser observada em várias entradas em que ela faz em seu diário dialogado ao longo do projeto. Nessas entradas, ela reflete sobre 
situações em sua prática profissional, dentro ou fora da sala de aula que, na maioria dos casos, mostram como ela realmente é preocupada com seus alunos:

\begin{abstract}
Nós estávamos falando sobre primeiro e segundo condicional, e os meus alunos acham o último tópico o mais difícil de todas as lições. Eu tentei apresentá-lo de modo mais simples: eu mostrei alguns exemplos, como "se eu fosse você, eu teria meu cabelo solto com mais frequência" (em inglês), e lhes pedi para também criarem algumas frases. Foi um exercício proveitoso e depois eu tinha certeza de que o segundo condicional pareceria mais real e significativo para eles. [...] Nós começamos a revisar os tópicos do exame por meio de algumas folhas que eu lhes dei. Eu me arrependi de não ter entregado as folhas com antecedência. Muito tempo precioso foi desperdiçado. Eu preciso organizar melhor a minha agenda. Eu não me sentia bem, me senti culpada, para fazê-los estudar por longo tempo durante a revisão, porque eles começaram o exame já cansados. Preciso pensar melhor em como usar meu tempo em sala de aula. Provavelmente será meu próximo ponto para melhorar em minha roda de coaching.
\end{abstract}

Esse excerto do diário dialogado do dia 27/09/2014 é exemplar e ilustra como Bárbara analisa muitas situações da sua prática na sala de aula, tentando utilizar as informações para chegar a conclusões sobre como melhorar seu ensino. Suas palavras são alinhadas com Schön (1983), que explica a reflexão sobre determinadas situações como uma busca de soluções para os problemas subjacentes, assim alcançando um melhor conhecimento profissional sobre si próprio como professor.

\title{
4.1.3e O pesquisador
}

Sendo parte integrante deste projeto no papel de pesquisador, também busquei descrever minhas reflexões no início e durante sua realiz ação. Um excerto das minhas notas de campo do dia 19/09/2014 ilustra as preocupações que tive durante a primeira metade do projeto:

Estou preocupado se vou conseguir manter a motivação até o fim desses 3 meses. Ambas as participantes parecem sempre cansadas e não conseguem preparar suas tarefas, o que retarda o nosso processo. Nós ainda estamos, mais ou menos, no início do nosso projeto, e eu espero que tudo dê certo.

Além de precisar saber como manter a motivação, a minha outra preocupação era com as participantes, que não tinham integralmente cumprido suas tarefas no processo de coaching até aquele momento. Outro excerto das minhas notas de campo do dia 10/10/2014 mostra minhas reflexões quando as participantes me perguntaram sobre minha opinião acerca do andamento do projeto:

Hoje as participantes me perguntaram se eu estou feliz com a forma como o projeto está indo em relação a elas. Sou grato, mas acho que eu deveria ser ainda mais grato. 
Planejar tudo em detalhe e esperar que as participantes façam exatamente como eu imagino é, definitivamente, "demais" da minha parte.

Fica evidente nesse excerto que, no momento da reflexão, compreendo que o projeto está indo bem, ainda que não estivesse sendo conduzido do jeito como eu imaginei antes. Outro excerto, também das minhas notas de campo (13/10/2014), mostra a minha preocupação com relação à obtenção de resultados concretos durante o projeto:

Agora estamos quase atingindo a metade do tempo do nosso projeto. Nós tentamos
várias coisas até agora, no entanto, eu ainda estou em dúvida se minha pesquisa vai
mostrar quaisquer resultados concretos... Eu tenho a sensação de que temos
praticamente perdido a parte "reflexiva" da pesquisa-ação até agora, as atividades
que foram apresentadas aos pares e experimentadas ainda não foram revistas em
detalhe. Eu preciso mudar isso! Também tenho que "insistir" com as participantes
para escreverem seus diários dialogados até sexta-feira. Nós também vamos
reescrever as rodas de coaching.

Minha intuição, registrada nessa nota de campo, a propósito da não occorência da reflexão como parte integrante do projeto manteve-se até o final da pesquisa.

\subsection{Coaching}

Esta seção da minha análise trata das associações espontâneas e das experiências que as participantes desse projeto têm em relação ao termo coaching. As associações espontâneas ilustram a ligação das professoras no que diz respeito ao termo coaching e, por outro lado, as experiências descrevem quais práticas desse procedimento elas conheceram durante sua vida profissional. Considero essas informações importantes, uma vez que elas refletem percepções das participantes de pesquisa a propósito do conceito de coaching bem como as possíveis preocupações em relação à pesquisa aqui relatada.

\subsubsection{Associações espontâneas e experiências}

Um excerto da primeira entrevista com a Maria, do dia 22/08/2014, mostra as associações espontâneas que ela relaciona com a palavra coaching:

Espontaneamente? Esporte! Futebol! Definitivamente o tênis, eu me lembro. Primeira vez que ouvi essa palavra foi quando eu estava na Inglaterra, porque eu queria jogar tênis, e eu tinha um coach de tênis. E, em seguida, coach de futebol. Mas nunca veio à minha mente coach em termos educacionais.

Segundo a professora, ela fez suas próprias experiências profissionais de coaching em duas escolas de línguas particulares diferentes. Assim, ela descreve sua primeira 
experiência com as seguintes palavras, como um excerto da primeira entrevista do dia 22/08/2014 mostra:

\begin{abstract}
Eu estava começando a trabalhar, ah sim, eu era uma novata lá, e realmente foi a minha primeira experiência como professora, como caloura. E eu tive esse coaching, que era tipo tutoria, uma professora me observou, ela me ajudou, e então foi uma coisa engraçada nas duas primeiras semanas, nós compartilhamos as aulas. Ela deu aula por 30 min, então eu dei $50 \%$ da aula, e ela deu os outros $50 \%$. Ela geralmente começava a dar aula, e depois ficávamos juntas e conversávamos sobre tudo. Com o passar do tempo, ela interferiu menos, e eu fiz as aulas por mim. Como ganhei confiança, isso é como aconteceu. E ela me observou até o final do semestre [...] foi uma vez a cada quinze dias. E prosseguiu, isso foi um bom treinamento para professores.
\end{abstract}

Outro excerto da mesma entrevista mostra outra experiência de coaching que ela teve em outra instituição:

Eu tinha uma coordenadora que fez isso, sabe, ela realmente treinou um grupo de professores, e então nós encontramos e conversamos, desenvolvemos nossos próprios materiais, e depois de dar uma aula juntos dávamos o feedback: isso aconteceu, "isso foi bom, aquilo foi ruim etc". Foi mais interessante, porque na outra instituição, foi algo individual, aqui foi uma coisa em grupo. [...] Nós fomos convidados, a coordenadora nos encorajou: "Oh, por que você não vão assistir a aula dessa pessoa", por exemplo: "Clara, vai assistir a aula da Maria”, então eu preferi este tipo de coaching.

Como mostram os excertos acima, Maria considera ambas as experiências de coaching úteis e positivas. No entanto, ela prefere a forma de coaching que foi aplicada em grupo, que parecia ter acontecido de uma maneira mais informal e sem restrições.

No caso de Bárbara, ela também associava coaching ao esporte, como o excerto de sua primeira entrevista (22/08/2014) indica: “Time (+++) ehhhmmm, manter-se (++) ehhh, eu penso sobre futebol, handebol, hmmm, deixe-me ver, coach (++) o que mais (++) a ideia de manter o pensamento sobre o que você está fazendo, ou o que deve fazer, é isso".

A associação espontânea dela era, como no caso de Maria, esportes, mas ela escreve sobre coaching com um certo tipo de reflexão a respeito da atuação de alguém. No entanto, percebo a partir da hesitação em sua resposta que demora algum tempo até ela conseguir manifestar uma ideia mais clara sobre o que esse termo realmente significa para ela.

Barbara teve sua primeira experiência com coaching numa escola particular de línguas, no início de sua carreira que ela descreve da seguinte forma no excerto da primeira entrevista do dia 22/08/20014:

Costumávamos ter muitas aulas de observação, com um observador na sala de aula. Sim, meu supervisor costumava assistir todos os professores uma vez por semestre, às vezes era a proprietária da escola, ela costumava assistir às nossas aulas uma vez 
por semestre também. Alguns dos outros professores também assistiam, então ela recolhia todo o feedback, e costumava escrever quais eram os problemas. [...] No início da minha carreira, eu me senti muito desconfortável, e quando o coordenador ou um dos meus amigos professores estivessem na sala de aula, eu fazia confusão em tudo, tudo dava errado, eu não estava confiante, meus alunos percebiam isso, eles tentavam me ajudar, fazendo seu melhor, tentando não cometer erros, mas era horrível. Ok, algum tempo depois, algumas outras vezes em que fui observada, eu me senti mais confiante, porque o meu nível de inglês havia melhorado muito. [...] No início foi uma má experiência, porque eu não estava madura, mas nas outras vezes, eu senti como se isso fosse necessário para minha prática.

Em contraste com Maria, que descreveu todas as suas experiências de coaching como positivas, percebo a partir das palavras de Bárbara que ela, no início de sua carreira, não gostava de ser observada nem treinada, o que mudou apenas depois de algum tempo, quando ela ficou mais confiante com o que ela estava fazendo.

\subsection{Peer Coaching}

\subsubsection{Atividades de peer coaching}

Na seção seguinte, algumas dessas atividades serão apresentadas, as quais se dividem em tarefas que foram realizadas, regularmente, durante as sessões de coaching e outras que foram aplicadas de forma irregular ou somente uma vez e, às vezes, fora das sessões de coaching semanais.

\subsection{1a Atividades realizadas durante as sessões de coaching semanais}

As participantes foram convidadas a apresentar atividades que atendessem as necessidades de seu par, conforme descrito acima. Para desenvolver essas atividades, elas poderiam usar qualquer tipo de recursos, como por exemplo, suas experiências pessoais, literatura ou informações disponíveis na internet, só para citar alguns exemplos. Algumas das atividades que foram realizadas pelas participantes no decurso deste projeto são apresentadas na seção seguinte.

Bárbara descreve, em seu diário dialogado, uma atividade chamada toll time que foi sugerida por Maria e, em seguida, aplicada em sala de aula. Nessa atividade, os alunos tiveram que fazer fila, no final da aula, em frente à porta e, individualmente, pronunciar corretamente uma palavra inglesa difícil que foi apresentada pela professora. Só aqueles 
alunos que conseguiram pronunciar a palavra corretamente poderiam sair. O excerto seguinte do dia 17/09/2014 mostra a reflexão da Bárbara:

Eu apliquei uma sugestão do meu par: toll time. Eu pedi aos meus alunos para
apontarem palavras que achavam muito difícil de pronunciar e ensinei-lhes as
pronúncias corretas. No final da aula, eu fiquei na porta pedindo-lhes que
pronunciassem uma palavra corretamente, como uma "senha" para sair. Foi muito
engraçado e os alunos gostaram do desafio. Apenas dois deles tinham que retornar
para o final da linha. Alguns minutos depois, um aluno me enviou uma mensagem
no celular dizendo o quão maravilhosa a atividade foi. Eles ficaram mais motivados
quando foram embora! E eu senti isso!

Observo, a partir desse excerto, que Bárbara percebe essa atividade como muito positiva, servindo como motivação adicional e enriquecedora para os seus alunos. Isso também se reflete numa das minhas próprias anotações de campo do dia 19/09/2014: "Bárbara tinha experimentado o exercício toll time que Maria havia sugerido como atividade criativa para sala de aula [...] e ela fez uma experiência positiva, por isso temos um bom primeiro resultado desta atividade".

A fim de apoiar as participantes com o projeto, eu também preparei algumas atividades, as quais apresentei durante nossos encontros. Já durante a primeira sessão de coaching, apresentei o formulário de autoavaliação (Apêndice F), que eu havia preparado para professores, baseado no fato de que ambas as participantes apontaram a "autoavaliação" em suas rodas de coaching como algo que elas gostariam de trabalhar.

Explicitei como esse formulário seria preenchido pelas professoras e respondi às perguntas delas. Ambas confirmaram que iriam utilizá-lo depois de uma das suas próximas aulas e, em seguida, dariam-me um feedback. No entanto, como outro excerto de minhas notas de campo (19/09/2014) indica, essa ferramenta não foi utilizada pelas professoras, no decurso do projeto: "Infelizmente, elas não tinham usado o formulário de autoavaliação para professores que eu tinha introduzido durante a última sessão de coaching, mas prometeram que iriam fazê-lo na próxima semana".

Um excerto da segunda entrevista com Bárbara (24/10/2014) mostra que ela se arrepende de não ter preenchido o formulário de autoavaliação durante o projeto: "Na verdade, não o preenchi, mas eu desejo ser capaz de fazê-lo nesta semana, como uma forma de resumir tudo, ou de envolver as minhas aulas nesta semana".

Na última entrevista do dia 27/11/2014, ela explica o porquê de não ter realizado esta atividade durante o projeto, como o excerto a seguir mostra: 
Ok, o formulário de autoavaliação para professores, eu não fiz essa atividade porque eu esqueci, e depois das aulas eu sempre estava muito cansada, e eu me esqueci completamente de fazê-la, e eu pensei que se eu a fizesse mais tarde não seria bom, porque talvez eu pudesse esquecer algo, ou perder uma informação importante, então eu desisti de fazê-la.

A partir de sua resposta, constato certo pesar por não ter aplicado essa atividade. Segundo Bárbara, foram a falta de tempo para fazer a atividade depois de suas aulas e a preocupação de fazê-la incorretamente que resultaram numa certa renúncia da professora, que decidiu por não aplicar a atividade.

Outra área que Bárbara tinha marcado em sua roda de coaching como algo que queria melhorar foram as habilidades de escrita. Por isso, Maria trouxe um livro com exercícios de inglês que ela emprestou para Bárbara, até o final do projeto. Um excerto do diário dialogado, do dia 10/10/2014, mostra como Bárbara reflete sobre isso:

Maria me emprestou um livro maravilhoso chamado "5-min activities". Com certeza, eu vou usá-lo muito. Ela me recomendou fazer uma atividade de escrita como warm-up/revisão, no início da aula. Ela explicou brevemente como fazê-la. Eu queria saber mais, mas eu me esqueci de perguntar para ela depois.

Apesar de estar satisfeita com o livro de Maria e com as ideias sugeridas nele, Bárbara parece estar desapontada por não ter recebido uma melhor orientação de seu par a respeito da realização dos exercícios. No entanto, depois ela relatou ter usado vários exercícios deste livro e fez experiências positivas, como uma das minhas notas de campo do 01/11/2014 mostra:

Bárbara falou sobre as atividades que conseguiu aplicar durante as últimas duas semanas. A primeira foi um exercício de escrita do livro de Maria: primeiro, ela tocou uma canção para seus alunos a fim de fazé-los relaxar. Depois disso, eles tinham 5 minutos para escrever sobre o que eles queriam. Os resultados foram de poesia, a rotina diária e o trabalho deles, entre outros. Ela utilizou o exercício com alunos de 3 diferentes níveis de pré-intermediário e relatou que ela teve algumas experiências muito agradáveis.

É evidente que Bárbara considera o exercício positivo, no sentido de que provocou certa criatividade nos alunos ao articularem suas reflexões. É interessante vê-la, apesar de não ter recebido uma instrução inicial satisfatória quanto à atividade sugerida por seu par, ter assumido o risco e realizado os exercícios com três níveis diferentes, o que de fato valeu a pena, segundo o feedback dela. Assim, fica evidente, para mim, que o compartilhamento de informações sobre o ensino e a aprendizagem promove um ambiente que promove a experimentação e a tomada de riscos, segundo sugere Robbins (1991). 
Outra atividade que foi apresentada por mim foi a chamada Mini-saga (Anexo A) que é uma história curta de exatamente 50 palavras. O exercício compreende várias etapas e tem como objetivo desenvolver as habilidades de escrita dos alunos - tema que ambas as participantes tinham marcado como áreas para trabalhar em suas rodas de coaching.

No entanto, apesar de ambas as professoras considerarem essa atividade interessante e confirmarem que a testariam com uma de suas turmas, foi apenas Bárbara que realmente fez isso algumas semanas depois, relatando que foi bem sucedida, embora tenha sido uma atividade considerada difícil por seus alunos.

Uma das atividades de peer coaching utilizadas já mencionada foi a roda de coaching, uma ferramenta utilizada pelas participantes, a fim de articularem as áreas que elas queriam trabalhar. As participantes preenchiam suas respectivas rodas e, durante a sessão de coaching seguinte, apresentavam o que elas tinham preenchido. Posteriormente, discutíamos os assuntos e as atividades subsequentes. As rodas de coaching eram copiadas e trocadas entre as colegas e mim.

A primeira opinião sobre essa roda de coaching, até então desconhecida para as participantes, reflete-se em um excerto do diário dialogado de Maria, do dia 12/09/2014:

Esta semana falamos sobre nossas rodas de coaching. Achei as ideias de Bárbara
interessantes, mas bastante vagas - eu queria mais detalhes. E eu sinceramente
pensei que a minha roda não adicionou qualquer ideia nova, pelo menos para mim,
não.
(Sim, eu concordo. Eu tenho uma dificuldade em ser objetiva e clara. Isso é algo que
eu estou lutando para mudar. Eu discordo quando você fala que sua roda não
adicionou qualquer ideia nova, suas ideias me inspiraram a escrever a minha!)

Observo, a partir desse excerto, certo ceticismo e desapontamento por parte de Maria, depois do uso inicial dessa ferramenta. No entanto, Bárbara, em parênteses, parece transformar o comentário negativo de Maria em algo positivo para si mesma: ela confirma a necessidade de ser mais clara consigo mesma sobre o que ela quer trabalhar e, ao mesmo tempo, fica inspirada pelas ideias de Maria.

O ceticismo de Maria, no entanto, parece ter mudado com o andamento do projeto, segundo ilustra o excerto da segunda entrevista com ela, do dia 24/10/2014:

A roda de coaching foi muito boa, foi nova para mim. Nunca fiz isso antes, portanto, foi ok. Eu me acostumei com a ideia. Eu me acostumei a fazer isso. A primeira vez que fiz isso eu realmente não estava, $(++)$ você sabe quando você não tem certeza sobre alguma coisa, (+) você não gosta, você a coloca de lado, mas, em seguida, a segunda roda foi muito mais interessante do que a primeira. 
É evidente que a preocupação inicial se baseia no fato de que a roda de coaching foi uma atividade nova, estranha para ela, o que também fica evidente na hesitação dela de como articular isso. No entanto, depois de familiarizar-se mais com a atividade e utilizá-la pela segunda vez, parece que a participante perdeu seu ceticismo inicial e começou a perceber os benefícios.

Por outro lado, apesar da dificuldade inicial, Bárbara entendeu a roda de coaching mais rapidamente, adquirindo gosto pela atividade, como mostra um excerto da segunda entrevista, do dia 24/10/2014: “A primeira vez que eu a vi, não gostei, porque não entendi como funcionava, mas então eu percebi que era realmente útil, e depois de alguns dias, eu comecei a gostar. É isso aí."

Como os excertos anteriores mostram, ambas as participantes, inicialmente, foram céticas sobre à roda de coaching, talvez por ser uma ideia nova para elas. Contudo, levou algum tempo até se familiarizem com essa atividade.

Em minhas notas de campo, eu também reflito sobre a roda de coaching, como um excerto do dia 09/09/2014 mostra. Nesse momento, estou muito satisfeito com os resultados da aplicação da roda de coaching e a reconheço como um grande benefício para as participantes:

Hoje eu me encontrei com Maria e Bárbara para falar sobre as rodas de coaching e
trocá-las entre as participantes. Elas foram convidadas a explicar o que tinham
preenchido nas diferentes seções das rodas em mais detalhes. [...] De qualquer
forma, em contraste com a reunião da semana passada, eu penso que hoje foi muito
produtivo, de maneira que, agora, fica muito mais claro para todos nós que
estaremos trabalhando. Então podemos realmente falar sobre medidas e ações
concretas nesta sexta-feira. Estou realmente ansioso por isso. Eu acho que a roda de
coaching seria uma boa ideia, já que as participantes tiveram que - em comparação
com "apenas" falar - entrar em mais detalhes e ser claras sobre quais são,
exatamente, os pontos que elas querem melhorar e anotá-los no papel. Isso foi
também confirmado pelas participantes que pareciam muito positivas hoje. Eu acho
que isso é essencial no que diz respeito ao projeto, pois é o ponto de partida para
outras ações. Estou feliz com isso.

4.3.1b Atividades realizadas fora das sessões de coaching semanais

Outra atividade que fez parte do projeto foi a observação em sala de aula mencionada anteriormente. Durante a pós-observação, o par, ao apresentar suas observações, não deve criticar o professor anfitrião, considerando o princípio no praise, no blame (sem elogio, sem acusação) (Gottesman, 2000). 
No entanto, este último ponto foi objeto de dúvidas por parte das participantes desde a introdução da atividade, como uma das minhas notas de campo do dia 19/09/2014 ilustra:

Eu apresentei a atividade "observação em sala de aula", passamos por ela e esclarecemos os pontos em aberto. As participantes foram orientadas a pensar em dois ou três pontos nos quais elas queriam ser observadas por seu par, na sala de aula, e anotá-los em seus documentos. Depois que eu expliquei o princípio "sem elogío, sem acusação", as participantes mostraram suas dúvidas, explicando que elas não podiam imaginar como dar feedback sem expressar sua opinião ou mostrar emoções.

As participantes desenvolveram uma atitude completamente negativa em relação a esse princípio, conforme outro excerto das minhas notas de campo do dia 03/10/2014 mostra:

Discutimos a observação de aula e especificamas os pontos nos quais elas queriam ser observadas. No entanto, ambas "reclamaram" do fato de que não devem solicitar pareceres ou uma avaliação das suas aulas. Especialmente Maria parece não gostar do princípio de como a observação de aula deve ser realizada, segundo a literatura. Ambas as participantes querem ser observadas e avaliadas uma em relação a outra. Elas diziam coisas como: "qual o sentido da observação em sala de aula se meu colega não puder comentar sobre meu ensino?"

Cada participante observou uma das aulas de seu par, sempre com o pesquisador. Os excertos a seguir mostram como essa atividade foi percebida, em última análise. Durante a pré-observação, Bárbara definiu os três tópicos sobre os quais queria ser observada: duração da fala do professor/dos alunos, a motivação dos alunos e a sequência lógica da aula.

Quando estávamos conversando, eu percebi que eu realmente precisava melhorar minhas habilidades de objetividade. Quase tudo que eu faço, eu não defino claramente as metas ou os pontos que quero alcançar; acho esse ponto em mim realmente horrível. Estou trabalhando arduamente para ser mais precisa, mas não é tão fácil. Eu devo ser mais objetiva quando falar sobre essas coisas.

No excerto anterior do diário dialogado de Bárbara, do dia 26/09/2014, depreende-se que ela percebe dificuldades em definir claramente seus objetivos exatos ao tentar estabelecer os pontos que gostaria de ser observada durante essa atividade. Assim, reconheço a tomada de consciência relatada por Fonseca (2009) que, resultante da reflexão sobre a prática em sala de aula, possibilita um maior entendimento dos fatos e o início de tentativas de modificação.

Assim, a própria observação na sala de aula é descrita de uma forma muito mais positiva, como outro excerto do diário dialogado de Bárbara, do dia 11/10/2014, mostra:

Bernd e Maria vieram para observar minha aula. Confesso que houve momentos em que eu me senti muito nervosa e eu até gaguejei, não sei o porquê. Na verdade, eu tenho uma ideia: talvez porque eles sejam professores de inglês "experientes". No entanto, tudo deu certo. Eles participaram das discussões propostas e ajudaram meus alunos com alguns exercícios. Foi uma aula maravilhosa, principalmente porque os meus alunos não tinham medo de correr riscos quando participavam dela. Eu trouxe alguns tópicos para serem discutidos, e os meus alunos deram seu melhor para 
indicar argumentos sólidos e defender seus pontos de vista. Além disso, essas discussões geraram muitos momentos de falar e escutar.

Observo que a ansiedade inicial de Bárbara na sala de aula se baseia, segundo sua própria interpretação, na curta experiência em ensinar inglês em comparação com Maria e comigo. No entanto, ela percebe que sua aula foi muito boa e os alunos também pareciam gostar da interação com Maria e comigo, porque estávamos ativamente integrados. O excerto também mostra que ela foi particularmente feliz em ver que seus alunos participaram ativamente nas discussões e se beneficiaram com as possibilidades de falar e escutar o que surgiu da interação.

No entanto, como mostra um excerto da segunda entrevista com Bárbara do dia 24/10/2014, ela refletiu mais ainda sobre essa atividade:

Ok, o "sem elogio, sem acusação" não funciona, eu não gostei desse princípio. Sim,
isso é cultural, porque não podemos, pelo menos para mim, não podemos fazer nada
sem envolver emoções, de certa forma. Então, é claro, se eu vir algo em sua aula, eu
não simplesmente vou descrevê-lo, vou dar a minha opinião. Não tenho certeza se
isso é certo ou errado, é assim que as coisas são [...] Além disso, os seus
comentários e os de Maria me fizeram entender, sim, que eu sou capaz de me tornar
uma boa professora.

O excerto mostra que Bárbara não gostou da ideia de um feedback que mitigasse qualquer tipo de opinião pessoal. No entanto, percebe-se que a observação da aula foi um sucesso, especialmente no percurso de sua aula e no feedback assertivo. Isso teve um efeito motivacional sobre ela e, ainda mais, foi como uma confirmação de que ela está no caminho certo para se tornar uma boa professora. Outro excerto de minhas notas de campo, do dia 18/10/2014, mostra como a pós-observação foi realizada:

Ambas deram um feedback sobre as aulas que haviam observado. Maria considerou
a aula de Bárbara dinâmica, motivante, engraçada, feliz, com uma forte presença
como professora, que sempre foi atenciosa. O feedback de Maria foi muito
emocional, e é óbvio que ela ficou muito contente com Bárbara por ser uma
professora tão comprometida. [...] Bárbara também comentou sobre a aula de Maria,
descrevendo-a como envolvente, motivadadora, "os alunos falaram muito, mesmo
cometendo erros, ela fez um bom exercício de pronúncia, ela controla o tempo muito
bem e faz os alunos falarem sobre si mesmos". [...] Essa sessão de feedback não
ocorreu do jeito que deveria supostamente ser. Em primeiro lugar, as participantes
não responderam exatamente aos pontos que elas deveriam observar, segundo o
desejo de seus pares. Em segundo lugar, é impossível não dar um feedback para
alguém que o peça explicitamente. Os participantes queriam uma opinião/avaliação
honesta e aberta sobre o seu ensino. "Sem elogio, sem acusação" é algo muito difícil
de ser aplicado em uma cultura interna tão emotiva, como a que percebi nas
participantes".

As palavras mostram que, embora ofeedback das participantes sobre a aula da colega tenha sido muito positivo, sobretudo porque focou em características gerais que foram 
percebidas pelos pares, o feedback específico de modo geral sobre as áreas que as participantes tinham solicitado para ser observadas não foi efetivo. Além disso, também confirmam que "sem elogio, sem acusação", como princípio fundamental de observação, recomendado na literatura, parece não funcionar no presente contexto.

Outra atividade que fez parte do projeto foi uma palestra na escola de línguas Casa Thomas Jefferson, sugerida por mim como atividade adicional para nosso projeto, com feedback por parte das participantes bastante positivo. A palestra foi realizada por um formador de professores norte-americano que prometia tratar sobre o desenvolvimento do vocabulário e motivação dos alunos por meio do uso de skype.

No entanto, a palestra não cumpriu suas promessas quanto aos conteúdos que foram anunciados anteriormente, como um excerto do meu diário dialogado (entrada a partir de 01/10/2014) demonstra: “A atividade externa na Casa Thomas Jefferson foi um tanto decepcionante, o professor nem falou sobre a motivação dos alunos nem sobre como usar skype para a comunicação online, ele só falou sobre verbos frasais".

Bárbara, que estava realmente motivada para participar desta atividade, reflete ainda no dia do evento, 29/09/2014, no seu diário dialogado:

Finalmente o dia da palestra! Eu queria saber como seria, fantástico ou horrível. Primeiro estivemos Bernd, eu e algumas outras pessoas desconhecidas. O professor levou questões interessantes sobre o ensino de vocabulário. Ele considerou o vocabulário o aspecto mais importante para o ensino de uma língua estrangeira. Eu sempre considerei o vocabulário como algo que os alunos aprenderiam com o passar do tempo. Depois de hoje, minha opinião sobre vocabulário em sala de aula será muito diferente da atual. Eu amei os exercícios. Vou tentar aplicar alguns deles nesta semana.

As palavras mostram que Bárbara estava realmente animada sobre sua participação nesse evento e mudou seu ponto de vista sobre um tema geral, que é o ensino seletivo de vocabulário. Ela até ficou motivada para aplicar alguns exercícios, em sala de aula, que foram apresentados na palestra. Isso está em consonância com a afirmação de Freitas (1996), segundo a qual, sem aplicar uma profunda sistematização, a reflexão já pode ser alcançada ainda que por meio de mera participação em eventos.

Outro excerto do diário dialogado, do dia 29/09/2014, de Maria reflete como a palestra foi percebida por ela e por Bárbara:

Eu assisti a uma palestra de um professor norte-americano de inglês na Casa Thomas Jefferson. Não gostei muito. Eu esperava algo novo. Eu achei um pouco 
aborrecido. [...] $\mathrm{Na}$ verdade, eu olhei ao meu redor na sala e vi que as pessoas estaram adormecendo ou olhando sem entusiasmo.

(Eu gostei das dicas que nos deu sobre como trabalhar em verbos frasais, mas na verdade a palestra deixou muito a desejar. Pessoalmente, eu também esperava mais. Eu tentei desfrutar essa oportunidade para refletir sobre todas as coisas positivas e úteis que eu poderia obter).

É evidente que as professoras expressam suas decepções quanto à palestra. Enquanto Maria a considerou entediante, indicando que estava esperando novas inspirações, Bárbara mostra que, apesar de não ter ficado muito feliz com a palestra em geral, ainda conseguiu extrair alguns aspectos positivos; no entanto, é interessante perceber que esse comentário sobre o evento é significativamente menos positivo, parece que ela relativiza a afirmação positiva que havia dado em seu próprio diário dialogado (veja acima).

Na segunda entrevista, Bárbara reflete mais uma vez sobre a palestra, segundo se observa no excerto da entrevista do dia 24/10/2014:

Bem, na verdade, não era o que eu esperava, mas eu gostei da forma como o
palestrante conduziu as atividades e sugeriu como aplicá-las. Para mim, é sempre
bom ouvir as pessoas falando inglês, porque acho isso importante para mim como
professora, e ouvir a pronúncia das palavras que uso todos os dias, como, às vezes,
não as pronuncio corretamente. Acho que a própria palestra não contribuiu para
minhas aulas, mas sim para a minha vida como professora.

Nessa última avaliação, Bárbara mostra um novo ponto de vista sobre o evento, diferente daquela opinião mostrada anteriormente. Concluo que ela está confusa quanto à maneira como foi capaz de se beneficiar dessa experiência.

Outra atividade que faz parte do projeto é a aplicação do chamado diário dialogado, como instrumento para promover a autopercepção e automonitoração das participantes. Alguns excertos mostram de que forma ele foi usado pelas participantes. Depois de ler as entradas do par, as participantes deveriam comentá-lo. Durante a apresentação do diário dialogado no início do projeto, indiquei às participantes que elas eram livres para expressar tudo o que quisessem dizer com relação ao projeto, positiva ou negativamente.

Em determinados pontos ao longo do projeto, elas enviaram por email seus diários a seus pares, com cópia para o pesquisador. As participantes foram convidadas a começar a escrever seus comentários sobre o projeto desde nosso primeiro encontro. Contudo, tive de lembrá-las várias vezes para não deixarem de escrever o diário. Em minhas notas de campo do 19/09/2014, coloco um primeiro comentário sobre isso, como o excerto mostra a seguir: 
celular e que iria anotá-lo o mais breve possível. Nós concordamos em trocar os diários por email até a próxima semana (24/09/2014).

Minhas palavras deixam transparecer que eu não fiquei muito feliz com o fato de as participantes não terem começado a escrever os diários, embora eu as tivesse lembrado várias vezes a fazê-lo. Na verdade, existem vários comentários nas minhas notas de campo que mostram que, permanentemente, tinha de lembrar e pedir às participantes que escrevessem e trocassem os seus diários dialogados ao longo do projeto.

$\mathrm{Na}$ primeira entrada de Maria, em seu diário dialogado, ela reflete sobre seus pensamentos iniciais sobre esse instrumento, como o excerto do dia 31/08/2014 mostra:

Eu não gosto de escrever diários, especialmente quando tem de ser lido por outra pessoa. Você sabe, deve ser pessoal, privado. Na verdade, tenho meu próprio diário, mas apenas escrevo sobre momentos importantes, de vez em quando, mas não todos os dias. Eu não sou muito de escrever, porque dá muito trabalho.

Suas palavras mostram claramente que ela considera um diário como algo para refletir sobre coisas pessoais e, portanto, rejeita a ideia de compartilhar seus pensamentos com outros. Além disso, ela também considera muito dispendioso, em termos de tempo, escrever um diário.

Depois da primeira vez que as participantes trocaram seus diários dialogados, Bárbara comentou sobre as entradas de Maria, como mostra o excerto do dia 29/09/2014:

Seu diário dialogado é muito legal. Sua escrita flui, tornando o processo de leitura uma experiência relaxante. Eu ri muito ao ler o que você escreveu. Eu podia imaginar você me dizendo essas coisas. Outra coisa a salientar é a sua honestidade: eu pude senti-la em cada palavra. Como visão geral das nossas semanas e da nossa participação neste projeto, eu acho que você descreveu com clareza e objetividade o que está acontecendo.

Maria também comenta sobre os pensamentos do diário dialogado de Bárbara. O excerto a seguir do dia 30/09/2014 mostra as reflexões dela sobre as entradas de Bárbara:

A primeira coisa que me surpreendeu sobre o seu diário era o seu entusiasmo, mais
precisamente sua energia. Você está muito aberta sobre o que você escreve. Eu acho
que isso é positivo para uma professora de línguas, especialmente em seus primeiros
anos de experiência de ensino. Eu gostaria de agradecer a você por seus comentários
amáveis sobre minhas ideias. Isso é o que eu chamo de encorajamento. E agradeço
também por me enviar sugestões com links para vídeos sobre o ensino de inglês. O
que eu vejo em vocês dois - incluindo o Bernd - é que vocês são acessíveis e
atenciosos. Eu tenho que confessar que hoje em dia eu me sinto um pouco cansada e
ansiosa para receber este tipo de apoio.

Durante a segunda entrevista do dia 24/10/2014, Bárbara comenta sobre o diário dialogado, conforme mostra o excerto a seguir: 
Sim, o diário é útil, mas é trabalhoso, sim, porque nós realmente precisamos parar por alguns minutos, 5 minutos, mas eu realmente gosto de escrever bem as coisas, você sabe, não apenas juntar as palavras, então preciso de alguns minutos para fazêlo bem. E eu achei que era realmente útil, e gosto disso, penso que é uma maneira de refletir.

A resposta de Bárbara indica que ela gosta do princípio do diário dialogado e, também, reconhece o benefício de escrevé-lo. No entanto, ela também entende que, a fim de refletir profundamente sobre as coisas, precisa-se de algum tempo.

No caso de Maria, parece que ela mudou sua opinião sobre essa ferramenta, durante o decurso do projeto. Um excerto das minhas notas de campo do dia 03/10/2014 reflete sobre isso:

Ambas, Bárbara e Maria, disseram que vão continuar a escrever seus diários, especialmente Bárbara parece ter escrito muito. Maria "confessou" que, inicialmente, não gostava da ideia do diário dialogado, mas isso mudou agora, ela realmente gosta dele! Isso é realmente uma boa notícia.

No entanto, Maria, logo depois, decidiu não continuar a escrever seu diário dialogado, sem dar mais explicações, ela apenas coloca um último comentário do dia 20/10/2014 no diário dela: "Eu me sinto cansada e deve ser por causa da baixa umidade. Não consigo me concentrar. Eu não vou escrever mais. Só na próxima semana para comentar a aula de Bárbara".

Nesse ponto, ela explicita o fato de se sentir cansada como razão para interromper a escrita. No entanto, outro excerto da segunda entrevista com Maria do dia 24/10/2014, parece mostrar a razão real de sua decisão:

Eu não gosto de escrever diários para outras pessoas lerem. Isso deve ser privado. De jeito nenhum. Eu sei que há um fim para isso, um objetivo, você disse, eu entendo isso, mas a ideia do diário dialogado, nunca, não. [...] A troca de experiências é ok, mas então aproveita para ser um diário. Estou escrevendo para você lê-lo, então não é um diário, é outra coisa. [...] Bárbara escreveu bastante, é muito interessante o que ela escreve, e ela não está constrangida nem envergonhada. Não é que eu estou envergonhada ou constrangida. Eu só não gosto da ideia de mostrar meu diário para outra pessoa. Não, se eu quiser que alguém leia meu diário, eu vou fazer isso, vou tomar a iniciativa: “por favor. leia-o!" É outra coisa.

Maria enfatiza mais uma vez, como em sua primeira afirmação no diário dialogado, que ela não gosta da ideia de compartilhar seus pensamentos com outras pessoas. Ela entende o diário como algo que é para ser lido somente pela pessoa que o escreve. No entanto, ela considera interessante ler as entradas de seu par. 


\subsection{Relações e Motivação}

Esta seção trata das relações entre as participantes e o pesquisador desta dissertação. Uma relação de confiança entre os participantes do projeto de peer coaching é um fator importante que deve ser considerado, conforme Robbins (1991). Além disso, vou descrever como as participantes definem o papel do pesquisador no contexto prático, o que será seguido por uma descrição de como a motivação das participantes se desenvolveu ao longo do projeto. Finalmente, vou ilustrar as mudanças que foram realizadas com relação ao andamento do projeto, bem como as minhas preocupações no papel de pesquisador.

\subsubsection{Relações participante/participante, participantes/pesquisador}

A análise de dados revela que, desde o início do projeto, as participantes têm uma relação amigável e respeitosa uma com a outra. Vários excertos do diário dialogado de Bárbara, registrados ao longo da primeira metade do projeto, mostram a admiração dela por Maria, conforme se observa nos seguintes excertos:

Eu vou trabalhar com Maria, uma professora fantástica e experiente que encontrei por duas horas, mas parece que temos sido amigas há anos (28/08/2014).

Ao ouvir todas as sugestões maravilhosas de Maria, também pensei "como estou agradecida de ter Maria como par neste momento"; ela tem me ensinado coisas incríveis, e quanto mais falamos, mais eu aprecio a experiência dela. Um dia, eu realmente gostaria de ser tão incrível como ela (19/09/2014).

Estou tão feliz de tê-la como minha colega. Estou aprendendo muito e um dia eu pretendo ser tão boa como ela $(03 / 10 / 2014)$.

As nossas reuniões sempre são incríveis, e hoje foi ainda mais legal porque Maria estava mais feliz do que na semana passada. Você sabe, eu me importo muito com ela. É estranho porque acabei de conhecê-la há três meses. Tudo depende da empatia (10/10/2014).

Esses excertos indicam que, embora conheça Maria há apenas pouco tempo, Bárbara já a considera uma boa amiga e um modelo com o qual ela pode aprender muito. Ainda mais importante, ela até mesmo a considera uma inspiração nesta pesquisa, no sentido de que Maria cria novas ideias que ela gostaria de seguir para melhorar a si mesma, como mostra o excerto do diário dialogado de Maria do dia 12/09/2014, quando Bárbara comenta sobre uma entrada de Maria: “[...] sua roda de coaching me inspirou a escrever a minha. Você é uma profissional tão maravilhosa!" 
No entanto, como outro excerto da segunda entrevista com Bárbara ilustra, no dia 24/10/2014, sua admiração vai ainda mais longe, ela não se considera capaz de se ver em condições de igualdade, em nível profissional, sentindo-se menor do que Maria:

\begin{abstract}
Sim, eu estou realmente feliz com Maria. Ela é uma pessoa tão especial, mas eu realmente gostaria de ser "mais", às vezes eu acho que eu não cumpro as expectativas dela. [...] Além disso, eu não tenho a experiência para dizer para ela "Oh, isso estava ruim, e isso estava bom", eu só achei muito interessante, tudo o que ela fez foi incrível para mim, porque eu sou uma professora novata, em comparação a ela.
\end{abstract}

De suas palavras, reconheço sua completa admiração por Maria, assumindo o papel do aprendente, quase incondicional, no processo. Por outro lado, Maria também mostra várias vezes o quanto ela gosta de Bárbara e que a considera uma boa amiga. Isto se torna evidente durante a segunda entrevista com Maria, como mostram os seguintes excertos, todos da segunda entrevista do dia 24/10/2014:

Bárbara está entusiasmada, ela apenas iniciou sua carreira, ainda está terminando seu curso de Letras. Ela está animada com isso, e ela valoriza tudo o que digo, porque estou madura, tenho mais anos de experiência. Esta é a verdade, eu acho que ela é uma pessoa muito otimista, ela levanta os espíritos, e isso é muito bom. Ela é uma pessoa agradável, ela não é invejosa, ciumenta, ela não é uma pessoa negativa. Eu não sinto nenhuma inveja de Bárbara como eu senti de outros professores, que é bobagem.

Eu acho que Bárbara está mais animada do que eu, ela está muito envolvida. Ela está indo para os EUA agora e está fazendo um monte de coisas, ela trabalha para duas escolas e tem alunos particulares, ela está fazendo seu curso de Letras, meu Deus, é demais para ela, é por isso que ela está tão cansada.

Espero que Bárbara mantenha seu espírito de motivação, ela tem motivação intrínseca, que é muito importante. Isso é mais importante do que a motivação extrínseca.

Foi muito bom, você sabe, compartilhar ideias com uma professora que está na fase inicial, ok, que não tem muita experiência, mas que é muito animada, dinâmica, e isso foi um estímulo para mim. Você sabe, ela tem um monte de energia, ela é impulsionada, ela é entusiasmada, algo que eu realmente estou perdendo. Esses aspectos, tive eles quando era muito jovem, mas eu não os tenho mais, porque estou perto da minha aposentadoria.

Maria atribui à Bárbara o papel de "novata", dinâmica, com pouca experiência, que traz motivação intrínseca e entusiasmo para sua profissão, esses aspectos, que ela também tinha quando era novata na profissão. No entanto, ela mostra que perdeu a maior parte destas características, por ter trabalhado muito e agora se preparar para a aposentadoria. Ela também está ciente do fato de que, para Bárbara, ela é um modelo, de quem todas as experiências são valiosas. 
Em seu último comentário sobre as entradas de Bárbara em seu diário dialogado, Maria, mais uma vez, fala diretamente para Bárbara e resume o que pensa dela como professora.

Eu gostaria de resumir os meus comentários dizendo que você é uma profissional
que trabalha bastante. Você é uma professora humana. Você detalhou seus
sentimentos e emoções. E embora você já tenha tido seus altos e baixos, você já
conseguiu superar essas coisas com sinceridade e alegria. Eu posso ver que você está
muito envolvida com o seu ensino. É uma paixão (13/11/2014).

As palavras dela indicam seu respeito por Bárbara e, ao mesmo tempo, expressam um elogio a seu ensino e à sua dedicação profissional.

Apesar dos diferentes papéis que elas parecem assumir e as diversas características que atribuem uma à outra, a relação delas se baseia em respeito e amizade que promovem um ambiente de confiança, essencial no contexto de peer coaching, como mencionado anteriormente. A despeito dos aspectos positivos que menciono, em algumas das interações entre as participantes, fica evidente a assimetria discursiva entre elas.

\subsubsection{Motivação e participação ao longo da pesquisa}

Considerando o que diz Gottesman (2000) acerca da dedicação dos participantes como pré-requisito para uma realização bem sucedida de um projeto de peer coaching, esta seção irá mostrar a motivação das participantes para contribuir ativamente durante o projeto. Como a participação é voluntária, é importante entender como a motivação ao longo do projeto se desenvolveu e como isso influenciou a vontade delas de desempenhar ativamente um papel no projeto.

Nesse contexto, o primeiro comentário em minhas notas de campo mostra que as duas participantes tinham, inicialmente, uma grande motivação, como o excerto do dia 19/09/2014 indica: "Eu tive uma impressão muito boa da sessão, as participantes pareciam estar motivadas, e vimos alguns primeiros resultados positivos das atividades que tínhamos experimentado".

No entanto, no caso de Maria, essa alta motivação inicial mudou durante o projeto, como atesta um excerto da segunda entrevista do dia 24/10/2014:

Fui voluntária inicialmente, mas pensando bem, às vezes a sexta-feira é um dia agitado, você está cansada, você não quer ir, o processo de vir para cá é cansativo. [...] No início, eu estava mais motivada porque eu pensei que eu teria mais tempo, 
mas agora estou cansada. Há coisas acontecendo, coisas lá fora, que estão interferindo neste projeto. [...] No início eu era tipo 5, agora estou tipo 4 ((numa escala de 1 (baixo) a 5 (alto)).

Ela justifica a diminuação de motivação por uma falta de tempo, causada pela interferência de motivos particulares, e também pelo fato de que as reuniões aconteciam todas às tardes de sexta-feira, depois de uma longa semana de trabalho. Um comentário em minhas notas de campo, do mesmo dia, mostra essa afirmação: "Também foi interessante ver que ela considerava tanto sua motivação quanto sua participação menor do que no início do projeto".

Esse declínio da motivação ainda continua até o final da pesquisa, como o seguinte excerto da terceira entrevista do dia 27/11/2014 mostra, quando ela foi convidada a dar uma avaliação de sua motivação numa escala de 1 (baixo) a 5 (alto): "No início, definitivamente 5; no meio, eu diria 4; e no final, eu acho que seria 3".

Em contraste com Maria, o nível de motivação de Bárbara tem comportamento contrário. A fim de ver como sua motivação desenvolveu do início até a primeira metade do projeto, ela também foi convidada para se avaliar em uma escala de 1 (baixo) a 5 (alto). Um excerto da segunda entrevista do dia 24/10/2014 mostra sua análise: "Talvez 3, porque eu não sabia quais eram as expectativas em torno do que deveríamos fazer, mas agora eu considero 5 , às vezes 4 , porque eu consegui ver o quanto eu melhorei desde que nós começamos, e isso me motiva".

A baixa motivação de Bárbara no início do projeto está vinculada ao fato de que ela não tinha certeza sobre o que seria sua participação no projeto. No entanto, ao longo do projeto, ela percebeu um aumento na motivação que foi causado pelos aspectos positivos percebidos por ela.

Embora a sua avaliação final, que ela articula na terceira entrevista, varie ligeiramente com relação à avaliação em uma escala, ela, mais uma vez, confirma que foram os aspectos e os resultados positivos que ela pôde perceber ao longo do projeto que a motivaram a continuar, como um excerto da entrevista do dia 27/11/2014 mostra:

Foi 4-5 no início, porque eu estava lidando com algo desconhecido para mim, na metade do tempo do projeto eu estava cansada, eu estava ficando cansada e exausta, porque eu estava fazendo um monte de coisas ao mesmo tempo, era 3-4, não quero ficar com apenas um número, porque estamos sempre num processo. E agora, no final, foi 4-5 de novo. Eu estava cansada, olhando para trás e pensando em todos os aspectos positivos nos quais eu consegui melhorar. 
Com base nesses excertos, concluo que a motivação de Maria e, consequentemente, sua participação ao longo do projeto reduziram, devido, segundo ela, à falta de tempo e interferências pessoais, enquanto que a motivação de Bárbara, que era baixa no início e alta no final, atingiu o seu maior nível no final do projeto, com base nas experiências positivas e nos benefícios que ela pôde perceber.

\subsubsection{Mudanças durante o projeto/especificações dos processos}

Esta seção vai tratar de algumas modificações que foram feitas com relação a certos processos, ao longo do projeto. Como se trata de um projeto piloto, considero importante mostrar a necessidade para essas modificações e como elas foram realizadas, a fim de refletir sobre o processo cíclico como caraterística da pesquisa-ação, que já foi mencionada anteriormente (KEMMIS; MCTAGGART, 2000).

O pano de fundo para a primeira ação foi o fato de que ambas as participantes apresentaram, com base nas áreas que ficaram marcadas nas rodas de coaching dos seus colegas, uma grande variedade de atividades. No entanto, essas foram apresentadas apenas em forma verbal e, em muitos casos, com narrativas baseadas em suas próprias experiências na sala de aula.

Como Maria pode referir-se a uma experiência muito maior do que Bárbara, as conversas ficaram, por vezes, unilaterais, deixando Bárbara num papel de passividade. Isso se reflete em um excerto de minhas notas de campo do dia 12/09/2014:

Foi uma sessão de coaching unilateral, com Maria falando muito sobre suas
experiências, descrevendo várias atividades e ideias que ela tinha experimentado
durante sua longa carreira como professora de inglês. Bárbara estava no papel
"passivo", ansiosamente ouvindo o que Maria dizia e tomando notas. [...] Eu acho
que é necessário manter as sessões e, especialmente, as ações mais estruturadas,
então eu anotei as atividades nas quais concordamos e enviei um e-mail para ambas
as participantes hoje, lembrando-as do que tínhamos concordado. Sugeri também
manter as atividades que elas sugeriram pelos seus pares em apenas uma por
semana, mas esta deveria ser preparada cuidadosamente, e em formato de papel
(com cópia para o par e para mim), a fim de melhor manter o controle sobre o que
nós estamos fazendo, e as áreas que queremos trabalhar.

Depois da metade do projeto, decidimos fazer uma revisão das rodas de coaching a fim de ver quais as áreas tinham sido trabalhadas com sucesso. Depois, as participantes foram convidadas a reescrever suas próprias rodas, omitindo as áreas que consideravam resolvidas, 
ao mesmo tempo adicionando novos temas que queriam trabalhar durante o tempo restante do projeto. Isso se reflete no excerto seguinte das minhas notas de campo do dia 17/10/2014:

Como o projeto já atingiu metade do tempo agora, pedi-lhes para reescreverem suas rodas de coaching, excluindo as áreas que nós já cobrimos, adicionando novos temas, se for necessário. Elas queriam um tempo para fazer isso em casa, com calma. Eu concordei, pedindo-lhes para trocarem as rodas de coaching depois, para que elas pudessem escolher um tema e, especificamente, prepararem uma atividade para a próxima semana.

As participantes também foram questionadas quanto à satisfação com a maneira como o próprio projeto e as atividades foram realizadas, durante a segunda entrevista do dia 24/10/2014. Ambas disseram que não tinham quaisquer sugestões ou ideias para mudanças, para o resto do projeto.

\subsubsection{Preocupações sobre as participantes}

Nesse ponto, gostaria de colocar alguns pensamentos que eu, no papel de pesquisador, tive ao longo desse projeto. Refleti constantemente sobre vários aspectos que me preocupavam, e pretendo ilustrá-los com maior detalhe nesta seção.

Uma das minhas preocupações era o fato de as participantes parecerem não manifestar os verdadeiros problemas que enfrentavam na sua prática. Este era um pensamento que eu tinha desde o início do projeto. Gottesman (2000) enfatiza a necessidade de os participantes de peer coaching entenderem esse processo formativo como alternativa para melhorarem suas habilidades e não para admitirem suas fraquezas.

Essa preocupação também aparece em minhas reflexões sobre a observação da aula que foi realizada com as participantes, em que ambas conduziram boas aulas muito bem preparadas. Um excerto das minhas notas de campo do dia 24/10/2014 ilustra:

Eu continuo me perguntando há algum tempo: estamos realmente trabalhando em quaisquer tipos de "problemas" da prática docente delas, ou elas já são "muito boas perfeitas", de alguma forma? Ou é possível que elas não queiram mostrar onde estão seus verdadeiros problemas? É uma coisa cultural? Talvez seja diferente quando elas ensinam uma gramática nova, desconhecida, ou quando elas fazem exercícios de leitura ou de escuta? Eu não sei. São elas que decidem sobre o que elas querem ser observadas e as áreas/temas nos quais elas querem melhorar, não sou eu.

Outro excerto que acrescentou essa preocupação foi o fato de que Maria, ao preencher a roda de coaching, se considerava como bastante competente na maioria das áreas que ela tinha marcado, o que se reflete nas minhas notas de campo do dia 05/09/2014: 
Embora ela tenha preenchido muitas das seções na roda de coaching, ela se considera bastante competente em muitas das áreas que ela marcou, por isso a minha preocupação é se haverá coisas suficientes para trabalhar, durante os próximos 3 meses!

Outra preocupação foi que Maria nem sempre parecia mostrar a vontade de investir tempo para preparar atividades específicas para sua colega Bárbara. Esse pensamento se reflete em uma das minhas notas de campo do dia 24/10/2014:

No entanto, quando eu perguntei qual atividade ela tinha preparado para Bárbara, ela disse: "eu lhe dei o livro para que ela possa aplicar algo em qualquer momento". Isso realmente não é a questão de peer coaching. Eu e Bárbara trocamos um "olhar eloquente" que significou "ela não fez nada, de novo", e eu não tenho certeza se Maria percebeu isso, acho que sim, porque depois da entrevista seguinte ela pediu desculpas por "não contribuir muito" para o projeto.

Esta ausência de prontidão de Maria também se reflete no primeiro comentário do seu diário dialogado, quando ela comenta sobre o fato de tê-lo escrito no excerto do dia 31/08/2014. "Eu não vou escrever muito porque é muito trabalho [...] De qualquer forma estou disposta a ajudar Bernd em seu projeto".

Depois da metade do projeto, ela desistiu de escrever o diário, mas continuou a comentar o de Bárbara. Outro ponto que é importante com relação ao contexto atual é a autopercepção das participantes. Um excerto da segunda entrevista (24/10/2014) com Maria revela mais informações sobre isso, quando ela reflete sobre a palestra na Casa Thomas Jefferson:

Você sabe, Bárbara disse coisas maravilhosas sobre o cara, mas ela tem apenas 23 anos de idade, ela apenas é uma novata. Olha, nós diríamos em português: "Sou uma macaca velha". Eu não posso dizer que foi uma palestra brilhante, não foi de todo! Não para mim.

Embora demonstrem cansaço e ceticismo em relação às possibilidades de buscar o melhoramento em sua profissão, essas palavras são prova de grande experiência e conhecimento, e isso é autopercepção, um princípio muito caro ao peer coaching. Essa autopercepção reflete-se, também, em outro excerto da segunda entrevista com Maria, do dia 24/10/2014. O pano de fundo para sua afirmação foi minha pergunta por que, em sua opinião, não foi possível encontrar um professor para substituir o participante da dupla que desistiu do projeto:

Sou uma exceção. Por quê? Eu dependo de mim mesma, eu quero melhorar, quero ensinar melhor. Se você vir, você fez um comentário muito interessante na observação de aula, você disse: "Ambas, você (Maria) e Bárbara, são professoras apaixonadas". Isso é verdade. Eu olho em volta para meus outros colegas, eles não são dedicados, eles não se importam, eles não estão interessados na profissão. 


\subsection{Avaliação das Atividades do Peer Coaching/Entrevistas ao longo do Projeto}

Nesta seção, apresento a avaliação das participantes sobre o projeto como um todo, bem como sobre as atividades que foram realizadas ao longo dos três meses.

\subsubsection{Opinião sobre o projeto (após a primeira metade do dele)}

Solicitei a Bárbara e Maria, durante a segunda entrevista, a compartilharem suas opiniões sobre o projeto em andamento. O excerto a seguir mostra a resposta de Bárbara do dia 24/10/2014:

Bem, eu acho que eu me sinto, de certa forma, mais preparada para ir para sala de
aula, porque eu poderia obter um feedback de outros professores que enfrentam os
mesmos problemas que eu enfrento, e eles têm soluções diferentes, e eu poderia
trabalhar com eles, poderia aplicá-las para alguns dos problemas que tenho, e
também aprendi muito durante essas seis semanas.

Ela relata estar mais confiante para enfrentar os desafios em sua vida profissional que, em sua opinião, deve-se ao fato de que ela pode experimentar diferentes soluções sugeridas por outros professores e aplicá-las, com sucesso, em sala da aula. Essa afirmação da professora se identifica com Gottesman (2000). Ela relata que o peer coaching promove o apoio mútuo bem como a transferência de conhecimentos entre professores, aumentando o autorrespeito deles.

Por outro lado, Maria menciona um único fator a essa pergunta, como mostra um excerto da segunda entrevista com ela, do dia 24/10/2014:

O aspecto que mais me atrai neste projeto é a partilha de ideias. É cansativo vir para cá numa sexta-feira à tarde. Sexta-feira deveria ser o meu dia de folga, temos outras coisas para fazer. Mas eu gosto de compartilhar ideias, eu gosto de olhar para seu rosto e o de Bárbara. [...] e eu sei que vocês são gente boa, então eu preciso partilhar ideias.

Nessa resposta, ela considera o compartilhamento de ideias e o aspecto social de fazer isso, conversando pessoalmente com outros professores, como os únicos benefícios da pesquisa aqui apresentada.

Para mim, reflete-se, na afirmação de Bárbara, que ela percebeu diferentes benefícios concretos como resultados das atividades de peer coaching até então, enquanto a resposta de Maria mostra claramente que ela atribui apenas uma baixa prioridade ao projeto. 
4.5.2 Melhoria das áreas marcadas na roda de coaching (após a primeira metade do projeto)

A pergunta se as atividades para as áreas inicialmente marcadas em sua roda de coaching ajudaram-na a melhorar, foi respondida por Maria da seguinte forma no excerto da segunda entrevista do dia 24/10/2014:

Parcialmente, sim. Eu não tinha tempo para fazer tudo, porque temos coisas,
prioridades, você sabe, você tem que fazer isso e aquilo para o teste, a coisa para a
conversação em sala de aula, você tem que fazer um monte de conversação, mas, ao
fim do dia, os alunos têm que fazer um teste, um teste escrito [...] Então, eu diria que
nós fizemos $40 \%$, ok, eu pude experimentá-lo, mas os outros $60 \%$ foram perdidos.
Não tinha tempo suficiente.

De acordo com a resposta, a baixa avaliação de Maria remonta ao fato de que ela não teve tempo suficiente durante as aulas para realizar essas atividades. Ela se refere ao fato de que os alunos são avaliados por provas escritas, e, portanto, a preparação para essas provas deixa muito pouco espaço para conversação.

Bárbara responde à mesma pergunta de uma forma diferente, como mostra um excerto da segunda entrevista do dia 24/10/2014:

Hmm (+++) (olhando para a roda de coaching) Ehm (+) sim, ela me ajudou, de uma
forma geral. (+) Mais precisamente, eu diria que os meus alunos estão muito
motivados em relação ao tempo do dia, por exemplo, quando começamos a estudar
sábado de manhã e conseguimos cumprir alguns dos pontos que eu anotei. Eu
consegui dominar melhor o meu próprio tempo de fala, e tentei falar menos, e eles
mais, porque eu quero que eles falem mais do que eu.

Eu percebo certa hesitação na resposta de Bárbara, suas palavras mostram que levou algum tempo para articular os benefícios que ela tem percebido. No entanto, ela descreve uma melhoria em algumas das áreas que tinha marcado inicialmente, em sua roda de coaching.

4.5.3 Diálogo com e feedback do colega (apòs a primeira metade do projeto)

Maria considera o diálogo e o feedback de Bárbara como muito útil no processo do peer coaching, como mostra o excerto da segunda entrevista do dia 24/10/2014: “O feedback dela foi muito útil. Bárbara está entusiasmada, ela apenas iniciou sua carreira, ainda está terminando seu curso de Letras. Ela está animada com isso, e ela valoriza tudo o que digo, porque estou madura, tenho mais anos de experiência”.

No entanto, ela não entra em detalhes, em vez disso ela elogia Bárbara e menciona que ela, como novata, demonstra um grande respeito por sua experiência. Em contraste, a resposta de Bárbara para a mesma pergunta é mais curta, mas, ao mesmo tempo, muito mais 
concisa e significativa, atribuindo à interação com Maria uma dimensão maior, como ilustra a seguinte frase da segunda entrevista do dia 24/10/2014: "CLARO QUE SIM! Isso me faz crescer profissionalmente, pessoalmente, sim".

Nessas últimas palavras, fica evidente que a partilha de experiências e ideias com outra pessoa resulta num avanço profissional, como é descrito por Almeida Filho (1995).

4.5.4 Expansão do conhecimento/melhorias/aprendizagem de novas habilidades

Quanto a saber se Maria poderia, ao longo do projeto, ampliar seus conhecimentos e melhorar ou adquirir novas habilidades, Maria se refere às atividades que foram apresentadas por Bárbara durante a sessão de coaching que aconteceu logo antes ela dar sua resposta, durante a segunda entrevista, como o excerto do dia 24/10/2014 mostra:

Sim, é muito interessante o que Bárbara acabou de mostrar para nós, as atividades diferentes que o professor do curso de Letras dela apresentou para melhorar o inglês dos estudantes! Então, é uma coisa de reciclagem, você está reciclando [...] Nós usamos esta expressão em português para tudo. Reciclagem. Reciclar ideias.

Sua resposta revela que ela acolhe novas ideias, como é o caso na situação específica que ela mencionou. No entanto, ela vê o projeto em si como algo que não fornece quaisquer novidades absolutas, ela o considera mais como oportunidade para renovar ideias existentes, conforme sua expressão "reciclagem" indica.

A resposta de Bárbara, por outro lado, mostra diferentes aspectos. O excerto da segunda entrevista do 24/10/2014 ilustra isso:

Este projeto me permite, entrar profundamente na minha prática de ensino, porque eu realmente amo o que faço, mas, por alguns anos, eu fiz isso como um trabalho, eu não estava prestando a atenção necessária, é por isso que eu gostaria de parar de trabalhar um pouco, eu não quero estudar e trabalhar tanto ao mesmo tempo, porque eu sou humana, não consigo, mas quero trabalhar bastante e estudar o que eu quero aplicar em minhas aulas.

A professora não menciona quaisquer áreas específicas de melhoria, no entanto, reconheço, em suas palavras, a compreensão da necessidade de realmente trabalhar em sua prática docente, o que, obviamente, nem sempre foi o caso durante sua carreira. 


\subsubsection{Autoavaliação (disposição/participação) durante o projeto (primeira metade)}

As professoras também foram convidadas a avaliar sua participação no projeto com relação às atividades e o envolvimento geral, numa escala de 1 (baixo) a 5 (alta). Maria respondeu da seguinte forma, como mostra o excerto da segunda entrevista do dia 24/10/2014: "Provavelmente 3,5, se eu fosse muito exigente, não 5 em tudo porque sei que, às vezes, estou atrasada, e isso conta, eu sei que, às vezes, eu não faço o dever de casa, tento ser pontual, às vezes, fico atrás do tempo, ok, as coisas são incompletas”.

Bárbara, por sua vez, deu uma resposta similar, como mostra o excerto da sua segunda entrevista, também do dia 24/10/2014:

Eu gostaria de dar um 4. Abraço este projeto como algo que é meu também, mas eu fico muito triste quando não posso aplicar todas as atividades que eu deveria, quando não posso escrever o meu diário dialogado, quando não consigo preparar as atividades.

Ambas as participantes constatam que os níveis de participação delas não são tão elevados como poderiam ser, devido a várias razões. No entanto, como as palavras de Bárbara mostram, ela parece estar mais desapontada com isso. Parece que ela atribui uma grande importância a esse projeto, o que, para mim, fica evidente no uso do verbo "abraçar".

\subsubsection{Como as participantes veem os benefícios do peer coaching}

Outra questão na terceira entrevista era como as participantes poderiam se beneficiar de seus pares. O excerto a seguir do dia 27/11/2014 mostra a resposta de Maria:

Bem, eu ouvi experiências, assisti a aula dela. Foi muito bom, você sabe, compartilhar ideias com uma professora que está na fase inicial, ok, que não tem muita experiência, mas que é muito animada, dinâmica, e isso foi um estímulo para mim. Você sabe, ela tem um monte de energia, ela é impulsionada, ela é entusiasmada, algo que eu realmente estou perdendo.

A fala de Maria revela que o benefício dela foi trabalhar com uma professora ainda iniciante que a inspirou com sua dinâmica e seu entusiasmo, coisa que ela vem perdendo ao longo da carreira. Contudo, o nível de envolvimento dela, ao longo da pesquisa, sugere que poderia ter sido incrementado mais se tivesse tido um real comprometimento com o processo de peer coaching.

Por outro lado, Bárbara articula, mais uma vez, o quanto ela pôde aprender com Maria para sua vida particular e profissional, e que ela a considera uma inspiração e um 
modelo que a motiva a seguir seu objetivo de se tornar em sua vida uma profissional tão boa quanto ela, como mostra o excerto da última entrevista do dia 27/11/2014:

Foi maravilhoso ficar próxima de Maria, porque ela tem, não sei, quase 30 anos de experiência, e eu tenho seis, então ela me ensinou muitas coisas: quando se trata de atitudes dentro ou fora da sala de aula como pessoa. Ela também me ajudou muito com meu inglês, com problemas de pronúncia, com as atividades durante alguns momentos críticos, como dias de recapitulação e outras coisas, e foi realmente gratificante compartilhar todas essas tardes com ela, porque ela pôde me mostrar, sim, que realmente vale a pena, "que você trabalha bastante, às vezes você fica cansada, muito cansada, exausta, mas se você amar o que você faz, virá bons frutos", é isso.

\subsubsection{O cumprimento das expectativas}

$\mathrm{Na}$ avaliação ao final do projeto, as participantes foram também convidadas a responder se foram cumpridas suas expectativas em relação ao projeto. $\mathrm{O}$ excerto a seguir da terceira entrevista com a Maria, do 27/11/2014, mostra sua avaliação:

Sim, a maior parte delas [...] Bem, se o projeto não for bem-sucedido, em parte, foi por minha causa, posso me culpar mesmo, porque eu não tinha muito tempo, eu estava muito cansada no final, a longo prazo. Então, eu acho que você fez um trabalho muito bom, o fato é que eu poderia ter feito muito melhor, mas eu não era tão boa quanto pensei. Desde o início, estava muito animada, provavelmente porque foi o início do semestre, e você teve sempre a esperança de acontecer algo novo, ok. [...] Basicamente, eu acho que mais de $50 \%$ foram bem sucedidos, cumpridos.

Em contraste, Bárbara responde à mesma pergunta da seguinte forma, como mostra o excerto da última entrevista do dia 27/11/2014:

Na verdade, eu não tinha muitas expectativas, porque não estava familiarizada com o projeto de verdade, eu não sabia do que se tratava, e eu dei-me a chance de conhecê-lo melhor, de saber o que deveríamos fazer, mas acho que as poucas expectativas que eu tinha, sim, elas foram cumpridas.

A resposta de Bárbara revela que suas expectativas, que, no início, eram baixas devido ao fato de que ela não sabia o que a esperava, foram cumpridas. No entanto, Maria atribui ao projeto um sucesso parcial, o que ela justifica com a diminuição da sua motivação ao longo dele e, também, em parte, por sua baixa contribuição.

\subsubsection{Aspectos que agradaram ou não as participantes}

Como parte da avaliação final, as participantes puderam responder que aspectos do projeto gostaram ou não. Na sua resposta, na última entrevista do dia 27/11/2014, Maria se exprime assim: 
Tivemos uma empatia entre nós três, ok, isso é muito importante. E nós trabalhamos bastante, tentamos fazer o nosso melhor, ok. Nós estivemos lá por uma razão, para compartilhar experiências, fazer as coisas, você sabe. Acho que foi muito interessante. Somos professores com um calendário lotado que nos impediu de trabalhar mais. Então, essa foi a principal razão, mas a coisa, no geral, foi muito interessante, eu tenho de dizer.

$\mathrm{O}$ interesse comum de trabalhar juntos e a empatia existente entre as participantes foram, para Maria, os aspectos que ela mais gostou e que ela considera como essenciais para o sucesso da pesquisa. Por outro lado, foi o tempo limitado que impediu a obtenção de um melhor resultado.

O seguinte excerto da última entrevista do dia 27/11/2014 mostra as reflexões de Bárbara, quando confrontada com a mesma pergunta:

Na verdade, eu adorei os momentos que partilhamos, porque é importante para mim como professora novata saber mais sobre outras pessoas, as experiências e os sentimentos que temos. Além disso, eu achei realmente impressionante discutir com vocês algumas questões, algumas outras questões "tabu", quando se trata de ensino de inglês, quando se trata da organização de uma escola, e aproximando-se a estas questões realmente é incrível quando nós estamos interessados em melhorar o ensino, não apenas pensando sobre como melhorar os salários, porque eu acho que, anteriormente, fui motivada por causa do dinheiro, mas agora eu realmente amo o que faço, e acho que aumentou dentro de mim uma paixão por isso.

Bárbara parece ter se beneficiado mais dos momentos de partilha entre as participantes e também da oportunidade de aprender com uma professora mais experiente. No entanto, ela também menciona um aspecto que ela não gostava de todo, que é o princípio "sem elogio, sem acusação" da observação em sala de aula, como fica evidente do seguinte excerto da terceira entrevista do dia 27/11/2014:

Não gostei muito do princípio "sem elogio, sem acusação", porque eu acho que, pelo menos para nós brasileiros, não funciona, nós somos pessoas muito emocionais e, com certeza, quando eu assistir à sua aula, eu vou lhe dar a minha opinião sincera, e eu vou lhe falar se foi ótimo ou não. Eu não sei, é quase impossível não ser parcial. Não podemos descrever se não podemos incluir nossas emoções, nossas opiniões.

\subsubsection{Reflexão crítica}

Durante a última entrevista do 27/11/2014, Maria descreve como sua reflexão mudou ao longo do projeto, o que se reflete no seguinte excerto da referida entrevista:

Me tornei mais consciente do meu ensino, isso mesmo, porque, anteriormente, eu não era. [...] Estou mais crítica. E eu percebi que tinha que melhorar algumas áreas, isso me ajudou muito, é essa a ideia, você sabe, porque você cresce em diferentes aspectos. 
Bárbara, quando solicitada, no final do projeto, a explicitar se ela percebeu uma mudança quanto à sua reflexão crítica, responde da seguinte forma no excerto da última entrevista do dia 27/11//2014:

Eu acho que mudou muito, desde o início, porque agora eu me considero mais crítica sobre a minha prática. Eu tento ser uma profissional melhor a cada dia, eu acho que, por algum tempo, tipo, não era motivada para fazer o meu melhor, eu apenas deixei tudo ir, e agora eu acho que essa energia me move, não sei, para tentar procurar mais informações, para tentar continuar.

Reconheço, a partir das respostas das professoras, que elas tiveram, ao longo desses três meses, desenvolvido certa conscientização, que resultou numa crítica mais elevada a respeito de suas práticas, segundo sugere Fonseca (2009) acerca da conscientização.

\subsubsection{Roda de coaching}

A roda de coaching, como descrita anteriormente neste trabalho, desempenha um papel importante sobre a indicação inicial das áreas que as participantes queriam trabalhar na pesquisa aqui relatada.

Por isso, é importante verificar as opiniões das professoras sobre a aplicação dessa atividade. Na última entrevista, Maria articula sua opinião sobre esse instrumento, como mostra o excerto da terceira entrevista do dia 27/11/2014:

Isso é um aspecto que achei extremamente importante, fundamental, essa roda de
coaching, porque eu nunca tinha feito isso antes, foi a primeira vez. E tenho que
dizer que eu queria ser uma professora perfeita, bem, $90 \%$ perfeita, mas eu não sou
[...], mas, você sabe, você não tem tempo suficiente para fazer tudo, esse é o
problema, eu não fiz tudo. Houve apenas um grupo de alunos onde eu consegui fazer
as quatro habilidades de forma equilibrada [...], mas com os outros, eu não acho que
tenha conseguido, estou crítica comigo mesma, então ler e falar foi tudo bem, eu
consegui fazer meus alunos falarem, mas ouvir e escrever, de jeito nenhum. Ficou
muito a desejar.

Com a ajuda da roda de coaching, as palavras de Maria revelam suas necessidades de aperfeiçoamento enquanto professora, contrariando o que ela mesma pensava anteriormente. Isto é um resultado muito positivo e fundamental, pois, mesmo com a longa experiência que sempre foi por ela enfatizada, é possível aperfeiçoar-se, principalmente se nos reportarmos aos princípios da formação continuada.

Bárbara, por sua vez, dá maiores detalhes em sua resposta, conforme o excerto da sua última entrevista, do dia 27/11/2014, mostra: 
Oh, minha maior preocupação foi a motivação dos alunos, as atividades na sala de aula, a correção de erros, o tempo de fala e a autoavaliação. Estou feliz em dizer que melhorei muito. Desde o início estava prestando mais atenção, eu estava prestando muita atenção em como eu estava lidando com questões dentro da sala de aula para envolver mais os meus alunos em tudo. [...] Eu consegui envolvê-los de maneira melhor e mudar alguns dos meus paradigmas sobre ensinar. [...] As atividades de sala de aula, deixe-me ver, sim eu dei mais oportunidades aos meus alunos para praticar o que eles estavam estudando, e isso fez toda a diferença [...] Sobre a correção de erros, acho que eu senti que os alunos ficavam mais confortáveis que antes, quando corrigidos [...] As questões de tempo de fala, eu pensava mais sobre como evitar falar mais do que eles em sala de aula, foi bom porque eu costumava fazer isso na escola onde eu trabalhei anteriormente, e agora eu voltei com essa prática de lhes dar as instruções para ler, sem apenas avisá-los, o tempo todo, sobre o que fazer. [...] E foi bom porque eles se expressaram, e isso é praticar também. [...] $\mathrm{Eu}$ acho que a roda de coaching me ajudou a organizar as dimensões que, na verdade, preciso para trabalhar, porque acho que eu sou uma professora realmente desorganizada [...].

Em comparação com seu par, Bárbara é mais específica em sua resposta, listando várias áreas que ela tinha marcado em sua roda de coaching, mostrando quais melhoras ela tem percebido. Ela também menciona outro benefício mais profundo resultante da aplicação desse instrumento, que é uma melhor organização da prática docente.

Mais uma vez, reconheço, nos excertos acima, a conscientização descrita por Fonseca (2009), no sentido de que ela possibilita às professoras, especialmente Bárbara, questionarem suas crenças e ideias sobre como ensinar e aprender línguas, e consequentemente, iniciarem tentativas de modificação.

\subsubsection{Aspectos que fizeram sucesso no peer coaching}

Outra questão da avaliação final do projeto, por parte das participantes, foi sobre quais aspectos tornaram o projeto um sucesso, e quais não o tornaram. Na sua resposta, Maria enumera uma série de fatores e explica de que forma tais fatores contribuíram para o sucesso da pesquisa, conforme se observa no excerto da última entrevista do dia 27/11/2014:

Bem, um dos aspectos que eu já tinha mencionado antes é a roda de coaching. A
autoavaliação é muito interessante para que você possa julgar a si mesma, para
ajudar a melhorar suas próprias habilidades de ensino, e eu considero a observação
de aula muito interessante para ver como os seus colegas tratam do ensino deles, a
discussão sobre muitas coisas, porque nós discutimos sobre várias coisas, tudo isso
ajudou muito. [...] Eu sou mais consciente do meu ensino, isso mesmo. Eu sou mais
crítica, porque antes eu não era. E eu percebi que eu tinha que melhorar algumas
áreas, então isso me ajudou muito, e é essa a ideia, você sabe, porque você cresce
em diferentes aspectos.

De forma semelhante, Bárbara menciona vários pontos que ajudaram a tornar o projeto bem sucedido, como sua resposta da terceira entrevista, do dia 27/11/2014, mostra: 
Acho que pude me beneficiar de tudo e de maneiras diferentes. Por exemplo, a sessão de coaching, nós estivemos lá, ficamos apaixonadas por alguns aspectos de nossa prática, e foi bom, porque eu precisava de algumas respostas, e eu também pude dar a minha opinião sobre algumas outras questões, e é bom ter voz. Então eu senti que era importante também. E a observação de aulas, foi ótimo ter vocês dois lá, porque vocês não eram os meus alunos, vocês não estavam seguindo minhas instruções, vocês estiveram me observando a fim de dar um feedback depois, e eu acho que isso é realmente necessário, quando você é uma professora. [...] Ok, o formulário de autoavaliação para professores eu não fiz essa atividade porque eu a esqueci, e depois das aulas eu sempre estava muito cansada, e me esqueci completamente de fazê-la, e pensei que se eu a fizesse mais tarde não seria bom, porque talvez eu pudesse esquecer algo, ou perder uma informação importante, então eu desisti de fazê-la. A discussão sobre determinados temas, acho que era incluída nas sessões de coaching, e as atividades propostas pelo par, amei o livro que Maria me deu, e também amei as dicas que ela me deu, como a de ligar aos alunos por telefone, você sabe, para fazê-los praticar, fora da sala de aula. O toll time foi muito engraçado, eles o adoraram, e a forma como a Maria trabalha na pronúncia me ajudou muito também.

4.5.12 Avaliação das participantes quanto à adequação do peer coaching à formação continuada

As participantes também foram questionadas se elas consideram o peer coaching como processo formativo adequado para a formação continuada de professores. Bárbara confirma isso na sua resposta, como mostra o excerto da última entrevista do dia 27/11/2014:

Claro, porque quando saímos da universidade, não somos [...] nada, porque nós realmente não sabemos como lidar com muitas coisas, e quando estiver no contexto de sala de aula real nós enfrentamos os desafios de verdade, então o peer coaching é, acho, uma ferramenta perfeita para manter os professores em movimento, porque nós nunca paramos, e nunca devemos parar, porque o conhecimento é o centro da nossa prática e o conhecimento está se movendo também. Há muitas coisas que estão, não sei, surgindo a cada dia, portanto, precisamos nos atualizar, temos de tentar melhorar a nossa prática, na minha opinião.

Depreendo desse texto que, para ela, o peer coaching é uma ferramenta excelente para os professores em serviço para desenvolverem-se melhor em suas práticas docentes, tendo em conta as mudanças permanentes que essa profissão enfrenta.

\subsubsection{A necessidade e/ou obrigatoriedade de peer coaching}

As professoras foram questionadas acerca de uma possível recomendação de um projeto de peer coaching a seus colegas professores. Além disso, se elas ainda levariam em consideração a possibilidade de uma participação obrigatória para elas mesmas e para os colegas em um projeto como este. Ambas as participantes responderam positivamente no que 
diz respeito à primeira questão, mas deram respostas diferentes em relação à segunda. A seguir, iniciamos a comparação com o excerto da entrevista de Maria, do dia 27/11/2014.

\begin{abstract}
Primeiro, eu recomendaria isso, depois, provavelmente, seria interessante se fosse obrigatório. [...] Especialmente porque já vi outros professores ensinando, e eu não gostava disso. Bárbara é muito boa, ela está no caminho certo, mas outros professores não estão. Tenho visto professores de inglês falando muito português, sobre suas vidas privadas, coisas pessoais que não eram relacionadas ao livro, é claro que há um tópico no livro, e você o expande, mas a ideia é falar inglês e falar sobre isso, você sabe, a fim de melhorar o seu inglês. Mas eu não vejo isso acontecendo muito, eu vejo professores só sentados, todos os estudantes ao redor, você sabe, ouvi um professor dizer para mim "olha, você está muito dinâmica, muito elétrica, você deveria apenas sentar e ensinar, como eu. Eu acho que você está fazendo uma coisa errada". Você sabe, ouvir isto não é muito agradável, não é muito motivador de todo.
\end{abstract}

Além de, inicialmente, propor o peer coaching para outros colegas, Maria ainda considera uma participação obrigatória como possível opção, o que ela justifica com a atuação e as atitudes em sala de aula de outros colegas professores que ela observou e não considera adequadas. Como o seguinte excerto da entrevista com Bárbara do dia 27/11/2014 mostra, ela também recomendaria o peer coaching para seus colegas:

Eu o recomendaria, porque eu acho que é uma escolha pessoal. Se você quiser melhorar a sua prática, sim, você tem que procurar soluções, como este projeto que fiz parte. E se fosse obrigatório, não daria certo, porque alguns professores não se dedicariam completamente para a prática, eles não estariam envolvidos completamente.

No entanto, de acordo com ela, o peer coaching só faz sentido se acontecer numa base voluntária, sem que os professores sejam obrigados a fazê-lo.

\title{
4.5.14 A propósito de refazer ou não outra atividade de peer coaching
}

Bárbara claramente confirma que ela novamente iria participar, no futuro, de um projeto de peer coaching semelhante, considerando-se cada vez mais madura depois desta experiência inicial. Ao mesmo tempo reconhece a necessidade de investir na sua formação contínuada, como mostra o excerto da última entrevista do dia 27/11/2014:

Sim, eu iria. E agora que eu tive essa primeira experiência, eu sei que eu tenho que poupar algum tempo para fazer essas atividades do jeito que deveriam ter sido feitas. E agora posso dizer que estou mais madura e sei que eu tenho que dedicar mais tempo para procurar ideias para melhorar, é isso.

No entanto, a resposta de Maria revela uma certa hesitação no excerto da terceira entrevista do dia 27/11/2014: "No futuro, eu provavelmente poderia, eu provavelmente faria. Provavelmente não no próximo semestre, mas no semestre seguinte". 


\subsubsection{Avaliação do pesquisador}

As professoras também tiveram a chance de fazer uma avaliação final sobre mim, no papel de pesquisador do projeto, também classificando o meu desempenho em uma escala de 1 (baixo) a 5 (alto). O primeiro excerto, do dia 27/11/2014, mostra a resposta de Maria:

Eu lhe daria 4,5. Houve um momento quando você se contradisse, e eu conversei com Bárbara: "Por que ele disse isso, se na semana anterior, ele havia dito algo totalmente diferente?". E isso me fez pensar, ou ele é muito ocupado e não anota corretamente as coisas, ou ele é esquecido [...]. É isso, me confundiu muito. Eu preciso ter a instrução certa. Ok, 4,5 para você, eu acho que você fez um trabalho muito bom, mas eu não lhe daria um 5 .

A resposta de Bárbara para a mesma questão mostra-se no excerto da última entrevista, também do dia 27/11/2014:

Eu avalio você com um 5, eu não sou "polidora", porque eu acho que você sempre preparou as coisas de antemão, você nos mostrou como fazer tudo, você foi paciente conosco, mesmo que tenhamos esquecido de fazer atividades ou de escrever o diário dialogado. Você nos lembrava por meio de e-mails amáveis [...]. Sim, eu não tenho nada a reclamar de você. Apenas nesse momento quando você disse, no início do projeto, que estaria conosco na observação de aula, e você mudou de opinião.

Embora as professoras tenham me avaliado positivamente, no meu papel de pesquisador, ambas também se referem a certo ponto ao longo do projeto que foi a observação na sala de aula. Depois de preparar essa atividade, em conjunto com as participantes, e confirmar minha participação nessa atividade, eu repensei minha decisão e as informei que eu não iria participar.

A razão para esta decisão foi simplesmente a ideia de tornar essa atividade a única sem a minha presença/participação ativa, durante todo o projeto. No entanto, esta decisão foi percebida negativamente, as participantes portaram-se como se tivessem sido ofendidas.

\subsubsection{Avaliação do projeto de peer coaching como um todo}

Ao final da terceira entrevista, as participantes tiveram a oportunidade de avaliar o projeto como um todo, e, além disso, numa escala de 1 (baixo) a 5 (alto), justificando suas respostas. O excerto da última entrevista, do dia 27/11/2014, mostra que Maria avaliou o projeto como muito bom, o que ela justifica com a boa participação de todas as partes envolvidas no processo:

O projeto foi bem-sucedido por sua causa, por causa de sua iniciativa. Eu nunca fiz um projeto como esse. E segundo, porque temos participado muito, Bárbara esteve 
muito envolvida. [...] Eu não acho que foi perfeito, mas eu daria um 4. Foi muito bom.

No entanto, a avaliação positiva do projeto como um todo por parte de Maria também contém uma reflexão muito crítica que se refere ao "sem elogio, sem acusação" como um princípio geral do peer coaching:

Bem, eu tenho a minha crítica sobre a ideia de peer coaching: não podemos fazer qualquer julgamento, isso é totalmente errado, as pessoas têm de aprender a ouvir. Olha, você não está fazendo a coisa certa, você tem que trabalhar bastante, você deveria trabalhar mais, ok, neste aspecto, é assim que tem de ser feito, com cada profissional. Você sabe "estou apenas olhando, mas eu não vou dizer se isso estiver certo ou errado" - por favor! Estamos perdendo nosso tempo, as pessoas têm que ter maturidade suficiente [...] A literatura é errada, tem que melhorar! A literatura norteamericana é errada porque não ajuda a melhorar. Eu acho que eles estão usando os princípios básicos de "Alcoólicos Anônimos", dizendo que não se pode criticar qualquer pessoa que bebe álcool. Há uma ideia psicológica por trás disso: nós nos reunimos para falar sobre o problema, mas não deveríamos chamar a atenção um ao outro. Eu acho que isso poderia funcionar para eles, mas é outra coisa. [...] Um professor deve saber o que ele ou ela está fazendo certo ou errado. Você sabe, o professor tem de melhorar neste aspecto. E alguns professores odeiam esta ideia, eles não estão preparados para aprender, mas penso que é uma característica da natureza humana, você sabe: "Eu não quero ser chamado a atenção, eu não quero ser avaliado, eu mesmo não quero ser criticado positivamente". Isso é errado, as pessoas têm de crescer, você sabe, crescer, psicologicamente.

É interessante perceber que Maria condena a literatura que promove esse princípio, comparando-a com as diretrizes dos "Alcoólicos Anônimos" que, de acordo com ela, supostamente discutem certas questões, mas, por questões psicológicas necessárias ao contexto, não estão autorizados a chamar a atenção uns aos outros. De acordo com Maria, todos os professores devem estar preparados para receber críticas diretas, a fim de melhorarem suas práticas.

Em contraste com a resposta extensa de Maria, a resposta de Bárbara é sucinta, como o excerto da última entrevista, do dia 27/11/2014, mostra: "Eu acho que eu avaliaria o projeto com um 4,5 [...]. Eu me lembro agora, esta é uma crítica para mim como participante do projeto. Eu acho que eu poderia ter me dedicado mais. Eu poderia ter participado mais". A avaliação dela atinge quase o valor máximo, no entanto, é interessante perceber que ela se responsabiliza pelos 0,5 pontos ausentes.

Após analisar os dados obtidos, vou apresentar, na seção seguinte, minhas considerações finais com relação aos resultados desta pesquisa. 


\section{REFLEXÕES FINAIS}

Investiguei, na pesquisa relatada neste texto, quais contribuições que a implementação de um programa de peer coaching como ferramenta para a educação continuada traz ao processo de desenvolvimento profissional no fazer pedagógico de professores de inglês. Ao retomar as duas perguntas orientadoras subjacentes a esta pesquisa, apresento, neste capítulo, minhas reflexões finais sobre os resultados obtidos.

\section{Como um programa de peer coaching pode ser utilizado na perspectiva reflexiva do ensino de inglês?}

A aplicação do peer coaching no contexto atual de ensino de inglês oferece diferentes possibilidades para uma perspectiva reflexiva. Ao longo do projeto, várias atividades foram vivenciadas pelas participantes, com efeitos diferentes.

A reflexão realizou-se, por um lado, em um nível individual para as participantes. A aplicação da roda de coaching, por exemplo, teve um papel importante, uma vez que contribuiu significativamente para desenvolver uma conscientização e, consequentemente, uma autorreflexão das professoras no que diz respeito à maneira de ensinar (FREITAS, 2009). Ao refletir sobre sua própria prática, cada uma delas percebeu a necessidade de melhorá-la, considerando a tomada de diferentes iniciativas.

No entanto, foram a cooperação e a influência, ainda que assimétrica, entre as participantes que possibilitaram uma reflexão colaborativa na pesquisa aqui relatada. As discussões regulares, a partilha de experiências e ideias, bem como a aplicação de várias outras atividades como a observação de aulas, por exemplo, ofereceram diferentes possibilidades para uma reflexão colaborativa.

Os esforços da reflexão individual e colaborativa as deixaram entrar em sua prática e criar vários resultados, como, por exemplo, a geração e transferência de conhecimento e a melhoria das áreas que queriam trabalhar, e, consequentemente, permitiram-lhes crescer profissionalmente.

A aplicação do peer coaching como alternativa para a formação contínua de professores em instituições educativas é um conceito aberto que não visa a seguir uma agenda rigorosa. $\mathrm{Na}$ verdade, consiste em analisar as necessidades dos participantes que estão, ao 
mesmo tempo, no foco de todos os esforços e no controle do processo de coaching, além de aplicações posteriores das atividades nas quais elas concordaram.

Essa reflexão deveria ser apoiada pela instituição na qual o peer coaching acontece, no sentido de que ela precisa mobilizar as pessoas e assegurar uma atuação sistêmica e democrática, como constata Alarcão (2004).

\section{Quais as opiniões das professoras participantes do peer coaching em relação a esse processo formativo?}

Tanto Maria quanto Bárbara tiveram, ao longo de três meses, várias oportunidades de dar opinião e de avaliar o projeto do qual elas participaram. Elas apreciaram essa oportunidade para expressar seus sentimentos positivos e negativos sobre vários aspectos do projeto.

Maria, que tem muitos anos de experiência em sala de aula, relata que ela tem se beneficiado mais das atividades colaborativas do peer coaching, como, por exemplo, da observação em sala de aula e das discussões durante as sessões de coaching. Ela gostou, especialmente, da partilha de experiências e foi inspirada pela motivação e pelo entusiasmo de seu par, Bárbara, que trouxe algumas novas ideias.

No entanto, ela também aponta que algumas outras atividades como a autoavaliação e, especialmente, a aplicação da roda de coaching permitiram-lhe ficar mais ciente sobre o fato de que, apesar de sua longa experiência, havia coisas que ela poderia melhorar em sua vida profissional. Essa reflexão, segundo ela, a levou a uma conscientização que lhe permitiu tornar-se mais crítica em relação à sua prática de ensino. Ao todo, ela considera este projeto uma experiência positiva, apesar de que, nem todas as expectativas que ela tinha inicialmente foram correspondidas.

Bárbara, como professora novata, com pouca experiência profissional, relata ter se beneficiado bastante da participação no projeto, considerando todas as atividades de peer coaching úteis, de certa maneira. Ela gostou muito da partilha de experiências e das discussões. De acordo com ela, a colaboração com seu par, que ela considera um modelo e uma inspiração para sua vida particular e profissional, deu-lhe a oportunidade de aprender e de experimentar novas atividades que a fizeram crescer profissionalmente. Ela também pôde 
melhorar algumas das áreas que tinha marcado em sua roda de coaching, o que ela também considera uma ferramenta muito útil para analisar a própria atuação.

Bárbara descreve outro ponto interessante ao dizer que se sentia como "ter uma voz", a fim de expressar que o projeto lhe deu a oportunidade de contribuir ativamente e dar sua opinião. Mesmo sendo uma professora novata, isto promoveu o sentimento de que ela é uma profissional séria. A combinação de todas as atividades de peer coaching fomentou o surgimento de uma conscientização e, consequentemente, levou a uma profunda reflexão sobre sua prática de ensino, reconhecendo a necessidade da formação contínua de professores, a fim de, constantemente, procurar novos conhecimentos. Embora nem todas as suas expectativas tenham sido cumpridas, ela considera o projeto um sucesso completo.

Houve também algumas questões ao longo desses três meses que as professoras não consideraram muito úteis ou positivas. Uma delas foi o fato de que elas mesmas tiveram de realizar a observação em sala de aula, sem a participação do pesquisador, o que elas consideraram quase uma quebra de promessa. Além disso, a palestra na Casa Thomas Jefferson foi percebida como pouco proveitosa, por não ter atendido às expectativas das participantes.

O "sem elogio, sem acusação" - como princípio basilar do peer coaching - foi considerado absolutamente irrealizável pelas participantes. Ambas as professoras questionaram fortemente essa regra e expressaram seu ressentimento sobre ela, em diversas ocasiões, afirmando que é impossível dar um feedback sem dar uma opinião pessoal. Além disso, as professoras explicitamente apontaram que elas querem receber a opinião de seu par, para obterem um ponto de vista diferente quanto ao seu ensino.

Ao avaliar as opiniões das duas professoras sobre o peer coaching, no meu papel como pesquisador, chego a conclusão de que foi Bárbara que mais aproveitou essa experiência, fato que se refletiu em diferentes situações, ao longo da pesquisa.

Por outro lado, parece que Maria, embora ela expresse por palavras, várias vezes ao longo da pesquisa, ter aproveitado a partilha de experiências e de ter sido inspirada pelo entusiasmo da colega "novata", não se beneficiou muito do peer coaching no sentido que tivesse impactado na sua prática como professora o que, a meu ver, não resultou num verdadeiro avanço profissional. 


\subsection{Contribuições da Pesquisa}

Ao implementar o peer coaching como processo formativo no fazer pedagógico de professores, busquei investigar os efeitos desse processo formativo como alternativa para a formação continuada de professores de inglês no Brasil.

Por várias razões, acredito no alto potencial dessa abordagem. Gostaria de destacar as mais importantes:

1. o peer coaching não segue orientações rigorosas. É, antes de tudo, um processo formativo flexível que também pode servir como um complemento aos esforços existentes em instituições educacionais;

2. há uma grande variedade de atividades;

3. todos podem participar;

4. o peer coaching não se limita a determinados países, instituições ou departamentos escolares;

5. a aplicação do peer coaching não depende de quaisquer decisões políticas oficiais;

6. as despesas financeiras para as instituições educacionais podem ser limitadas a valores mínimos.

Espero que as contribuições desta pesquisa sirvam como estímulo e ponto de partida para um maior desenvolvimento de práticas colaborativas na área da Educação.

\subsection{Limitações da Pesquisa e Propostas para Estudos Futuros}

Considero relevantes as pesquisas que lidam com formas alternativas para uma formação continuada de professores de línguas, a fim de encontrar novas possibilidades para se refletir sobre as práticas de ensino. Contudo, estudos que discutem formas colaborativas de aprendizagem e ensino e, particularmente, o coaching ou áreas afiliadas ainda são recentes no contexto educacional brasileiro e, por isso, merecem maior atenção.

Levando em conta o fato de que a presente pesquisa sobre peer coaching, como subcategoria do coaching, foi um projeto piloto com literatura disponível apenas em inglês, a troca de experiências com outros pesquisadores foi relativamente difícil, fato que, 
possivelmente, não contribuiu para obter resultados mais relevantes. Outros fatores como o tempo limitado das professoras ao longo do projeto, devido a grande carga de trabalho em suas vidas profissionais, a pouca experiência com relação ao coaching de todos os indivíduos envolvidos na pesquisa, a duração do projeto de apenas 3 meses e o fato de que um participante da segunda dupla desistiu do projeto, impediram-me de alcançar resultados comparativos entre as duplas e, consequentemente, mais aprofundados.

Outro aspeto que impediu a obtenção de resultados mais relevantes foi a grande diferença da experiência profissional das participantes, fato que se reflete em vários pontos da análise de dados e que, consequentemente, resultou numa constelação unilateral na interação entre as participantes, descrito por Steger (apud Dittmann, 1979, p.5-6) como "diálogo assimétrico". Isso significa que uma das participantes, no presente contexto, Maria, ficou com o privilégio de lidar com a interação no sentido de indicá-la, dirigi-la, orientá-la e conclui-la, o que, eventualmente, deixou Bárbara mais reverente, assumindo um papel mais passivo ao longo do processo de peer coaching.

Assim, apesar de todos os apectos positivos que esta pesquisa revelou sobre o peer coaching, mostra-se também que a realização de atividades colaborativas e, consequentemente, o alcance de resultados significativos, depende muito das caraterísticas pessoais dos participantes como, por exemplo, a atitude, a prontidão, o compromisso e a abertura deles para tentar novas experiências.

Alguns temas a respeito do assunto desta pesquisa, a fim de ampliar o conhecimento sobre as práticas de coaching e peer coaching, começam a surgir ao final da análise dos dados. Dentre eles, posso apresentar os seguintes:

1. medidas possíveis para instituições educacionais na colaboração com os professores no processo de peer coaching;

2. combinação do peer coaching com formas existentes de práticas colaborativas em instituições educacionais;

3. possibilidades para a implementação do peer coaching no nível institucional;

4. implementação do peer coaching em escolas públicas;

5. peer coaching para professores iniciantes vs professores experientes. 
Espero que essas sugestões e os resultados desta pesquisa sejam promissores e possam inspirar e motivar outros pesquisadores a envidar mais esforços em busca de novos caminhos que visam à melhoria do ensino de inglês no Brasil. Espero, também, que os resultados possam estimular mais o processo de formação continuada de professores não apenas de inglês, mas de outras línguas e de outras áreas, em todo o mundo. 


\section{REFERENCIAS}

ADELMAN, C. The Practical Ethic Takes Priority over Methodology. In CARR, W. (Ed.) Quality in Teaching: arguments for a reflective profession. Brighton: Falmer Press, 1989.

ALARCÃO, I. Professores reflexivos em uma escola reflexiva. São Paulo: Cortez, 2004.

ALMEIDA FILHO, J.C.P. Dimensões Comunicativas no Ensino de Línguas. Campinas: Pontes, 1993.

. Tendências na formação continuada do professor de língua estrangeira. Campinas: Unicamp: Mimeo, 1995.

O Ensino de Línguas no Brasil de 1979: e agora? Revista Brasileira de Linguística Aplicada, 1, 2001. 15-29.

Pontes, 2005.

Linguística Aplicada ao Ensino de Línguas e Comunicação. Campinas, SP:

Análise de Abordagem Como Procedimento Fundador de Autoconhecimento e Mudança Para o Professor de Língua Estrangeira. In: ALMEIDA FILHO, J.C.P. O Professor de Língua estrangeira em Formação. 3. ed. Campinas: Pontes Editores, 2009. p. 11-27.

ARAÚJO, A. Coach: um parceiro para o seu sucesso. São Paulo: Gente, 1999.

ARFUCH, L. La entrevista, uma invención dialógica. Barcelona: Paidós, 1995.

BAKER, R.; SHOWERS, B. The Effects of a Coaching Strategy on Teachers' Transfer of Training to Classroom Practice: a six-month follow-up study. Apresentado na reunião anual da American Educational Research Association, New Orleans, 1984.

BARCELOS, A.M.F. A Cultura de Aprender Língua Estrangeira (Inglês) de Alunos Formandos de Letras. Dissertação de Mestrado em Linguística Aplicada. ed. Campinas: IEL/UNICAMP, 1995.

A Cultura de Aprender Línguas (inglês) de Alunos no Curso de Letras. In: ALMEIDA FILHO, J.C.P. O Professor de Língua Estrangeira em Formação. 3.ed. Campinas: Pontes Editores, 2009. p. 157-177.

. Lugares (Im)Possíveis de se Aprender Inglês no Brasil: crenças sobre aprendizagem de inglês em uma narrativa. In: LIMA, D.C. Inglês em Escolas Públicas não Funciona: uma questão, múltiplus olhares. São Paulo: Parábola Editorial, 2011. p. 147-158.

BARKLEY, S.G. Quality Teaching in a Culture of Coaching. Lanham: Scarecrow Education, 2005.

BARTH, R. Improving Schools from Within: Teachers, Parents, and Principals Can Make the Difference. San Francisco : Jossey-Bass, 1990.

Introduction. In: GOTTESMAN, B. Peer Coaching for Educators. 2.ed. Lanham: The Scarecrow Press, 2000. p. xiii-xiv. 
BARTLETT, L. Teacher Development Through Reflective Teaching. In: RICHARDS, J.C.; NUNAN, D. Second Language Teacher Education. Cambridge: Cambridge University Press, 1990. p. 202-214.

BASSEY, M. Action Research for Improving Educational Practice. In: HALSALL, R. Teacher Research and School Improvement. Buckingham: Open University Press, 1998. p. 167-178.

BECKER, J.M. Peer Coaching for Improvement of Teaching and Learning. [S.l.]: [s.n.], 2011.

BLATYTA, D.F. Mudança de Habitus e Teoria Implícitas - uma relação dialogada no processo de educação continuada de professores. In: ALMEIDA FILHO, J.C.P. O Professor de Língua Estrangeira em Formação. 3.ed. Campinas: Pontes, 2009. p. 63-81.

BOGDAN, R.C.; BIKLEN, S.K. Qualitative Research for Education: an introduction to theory and methods. Needham Heights: Allyn \& Bacon, 1998.

BRASIL 1. Primeira Lei de Diretrizes e Bases da Educação. Disponível em: $<$ http://www2.camara.leg.br/legin/fed/lei/1960-1969/lei-4024-20-dezembro-1961-353722normaatualizada-pl.pdf $>$. Acesso em: 03. jul. 2015.

BRASIL 2. Segunda Lei de Diretrizes e Bases da Educação. Disponível em: <http://www.camara.gov.br/sileg/integras/136683.pdf>. Acesso em: 03. Jul. 2015.

BRASIL 3. Parâmetros Curriculares Nacionais: terceiro e quarto ciclos do ensino fundamental: língua estrangeira. Brasília: MEC/SEF SECRETARIA DA EDUCAÇÃO, 1998.

CANDAU, V.M. Magistério: construção cotidiana. 4. ed. Rio de Janeiro: Vozes, 2001.

. Formação Continuada de Professores: tendências atuais. In: REALI, A.M.M.R.; MIZUKAMI, M.D.G.N. Formação de Professores: tendências atuais. 2.ed. São Carlos: EdUFSCar, 2007. p. 139-152.

CARDOSO, C.A. Formação Crítico-Reflexiva: a relação teorica e prática. Integração: ensino-pesquisa-extensão, São Paulo, 01 Agosto 2002, p. 212-215. Disponível em: <http://www.usjt.br/prppg/revista/>. Acesso em: 10. nov. 2014.

CARO, D.; ROBBINS, P. Talk Walking: Thinking On Your Feet. A Strategy for Professional Enrichment, Experience and Exercise. The Developer, November 1991.

CARRUTHERS, J. The Principles and Practices of Mentoring. In: CALDWELL, B.J.; CARTER, , E.M.A. The Return of the Mentor: Strategies for Workplace Learning. London: Falmer Press, 1993.

CAVALCANTI, M.C. O discurso do professor de línguas: Implicações para a formação do professor. Mesa Redonda - Método e Discurso do Professor. Simpósio interuniversitário. Unicamp e PUC/SP: [s.n.]. 1990. 
CAVALCANTI, M.C.; MOITA LOPES, L.P. Implementação de Pesquisa na Sala de Aula de Línguas no Contexto Brasileiro. Trabalhos em Linguística Aplicada, v.17, p.133-144, 1991.

CELANI, M.A.A. Considerações Sobre a Disciplina Prática de Ensino de Inglês nos Cursos de Licenciatura. In: CELANI, M.A. Ensino de Línguas. São Paulo: Cadernos PUC, v. 17, 1984. p. 70-77.

- Um Programa de Formação Continuada. In: CELANI, M.A.A. Professores e Formadores em Mudança. São Paulo: Mercado de Letras, 2003. p. 19-33.

Prefácio. In: TELLES, J.A. Formação Inicial e Continuada de Professores de Línguas: dimensões e ações na pesquisa e na prática. Campinas: Pontes Editores, 2009. p. 912.

CELANI, M.A.A.; COLLINS, H. A formação contínua de professores em contexto presencial e a distância: respondendo a desafíos. In: BÁRBARA, L.; RAMOS, R.C.G. Reflexões e ações no ensino-aprendizagem de línguas. Campinas, SP: Mercado de Letras, 2003. p. 69-105.

CHAGAS, V. Didática especial de línguas modernas. São Paulo: Companhia Editora Nacional, 1979.

CHIZZOTTI, A. A Pesquisa Qualitativa em Ciências Humanas e Sociais. Petrópolis: Vozes, 2006.

CLUTTERBUCK, D. Coaching The Team At Work. 3.ed. London: Nicholas Brealey Publishing, 2010.

COHEN, L.; MANION, L. Research Methods in Education. London: Routledge, 1994.

COHEN, L.; MANION, L.; MORRISON, K. Research Methods in Education. 7.ed. Abingdon, UK: Routledge, 2011.

CRESWELL, J. Educational Research: planning, conducting and evaluating quantitative and qualitative research. Upper Saddle River: International Pearson Merril Prentice Hall, 2008.

CUNHA, A.G. Instructional coaching: a promising in-service foreign language teacher education experience. 2014. PhD dissertation in Applied Linguistics. Graduate Program in Linguistic Studies: Federal University of Minas Gerais, Brazil.

DENZIN, N.K.; LINCOLN, Y.S. Introduction: entering the field of Qualitative Research. In: DENZIN, N.K.; LINCOLN, Y.S. Handbook of Qualitative Research. Thousand Oaks, California: SAGE Publications, 1994. p.1-17.

Introdução: a disciplina e a prática da pesquisa qualitativa. In: DENZIN, N.K.; LINCOLN, Y.S. Planejamento da Pesquisa Qualificativa: teoria e abordagem. Porto Alegre: Artmed, 2006. p. 15-41.

DEWEY, J. The quest for certainty: a study of the relation of knowledge and action. New York: Minton, Balch \& Company, 1929. 
. How we think. In: KOLESNICK, W.B. Mental discipline in modern education. Madison: University of Wisconsin Press, 1958.

DIGGINS, J.P. The Promise of Pragmatism: Modernism and the Crisis of Knowledge and Authority, Chicago: University Of Chicago Press. 1994.

DITTMANN, J. Einleitung - Was ist, zu welchen Zwecken und wie treiben wir Konversationsanalyse? In: DITTMANN, Arbeiten zur Konversationsanalyse. Tübingen: Max Niemeyer, 1979. p. 1-43.

DUFF, P.A. Research Approaches in Applied Linguistics. In: KAPLAN, R. B. The Oxford Handbook of Applied Linguistics. New York: Oxford University, 2002. p. 13-23.

DUTRA, D.P.; MELLO, H.A. A prática reflexiva na formação inicial e continuada de professores de língua inglesa. In: ABRAHÃO, M.H.V. Prática de ensino de línguas estrangeiras: experiências e reflexões. Campinas: Pontes, 2004.

EL ANDALOUSSI, K. Pesquisas-ações: ciências, desenvolvimento, democracia. São Carlos: EdUSCar, 2004.

ERICKSON, F. Qualitative methods in research on teaching. In: WITTROCK, M.C. Handbook of research on teaching. New York: Macmillan, 1986. p. 119-161.

FELIX, A. Crenças de Duas Professoras de Uma Escola Pública Sobre o Processo de Aprender Língua Estrangeira. In: ALMEIDA FILHO, J.C.P. O Professor de Língua Estrangeira em Formação. 3. ed. Campinas: Pontes Editores, 2009. p. 93-110.

FERRANCE, E. Action Research. Providence, RI: Northeast and Islands Regional Educational Laboratory at Brown University, 2000.

FINCH, A. Action Research: empowering the teacher. Pleiades: Journal of Teaching Young Learners of English, v. 1, n. 1, , 2005. p. 30-48.

FLICK, U. An Introduction to Qualitative Research: theory, method and applications. London: Sage, 1998.

FONSECA, M.R.F.S. Prática e Teoria na (Trans)Formação de Professores de Língua Estrangeira. In: ALMEIDA FILHO, J. C. P. O Professor de Língua Estrangeira. 3.ed. Campinas: Pontes Editores, 2009. p. 83-92.

FREEBODY, P. Qualitative Research in Education: interaction and practice. London: Sage, 2003.

FREEMAN, D. Teacher training, development, decision making: A model of teaching and related strategies for language teacher education. TESOL Quarterly, v.23, n.1, p. 27-45, 1989.

FREIRE, P. A Educação na Cidade. São Paulo: Cortez, 1991.

Pedagogia de Autonomia: saberes necessários à prática educativa. 35. ed. São Paulo: Paz e Terra, 2007. 
FREITAS, H.C.L. Certificação Docente e Formação do Educador: regulação e desprofissionalização. Educação e Sociedade, Campinas, v. 24, , 2003. p. 1095-1123.

FREITAS, M.A. Uma análise das primeiras análises de abordagem de ensino do professor de língua estrangeira. Campinas UNICAMP, Dissertação de mestrado: [s.n.], 1996.

Avaliação Enquanto Análise: resultados das primeiras reflexões do professor de L.E. sobre o próprio ensino. In: ALMEIDA FILHO, J.C.P. O Professor de Língua Estrangeiras em Formação. 3. ed. Campinas: Pontes, 2009. p. 51-62.

FULLAN, M.; BENNETT, B.; ROLHEISER-BENNETT, C. Linking Classroom and School Improvement. Annual Meeting of the American Educational Research Association , San Franciso, 1990.

GALLWEY, W.T. The Inner Game of Tennis. London: PanMacmillan, 1975.

GATTI, B.A. Análise das Políticas Públicas para Formação Continuada no Brasil. Revista Brasileira de Educação, v. 13, n. 37, jan.-abr. 2008.

GENTILE, P. Professor se Forma na Escola. Revista Nova Escola, 2003. Disponivel em: <http://revistaescola.abril.com.br/formacao/formacao-continuada/professor-se-forma-escola423256.shtml>. Acesso em: 10. nov. 2014.

GERALDI, C.M.G.; MESSIAS, M.D.G.M.; GUERRA, M.D.S. Refletindo com Zeichner: um encontro orientado por preocupação política, teóricas e epistemológicas. In: GERALDI, C.M.G.; FIORENTINI, D.; PEREIRA, E.M.D.A. Cartografias do Trabalho Docente professor(a)-pesquisador(a). Campinas: Mercado das Letras, 1998.

GIMENEZ, K.M.P.; MATEUS, E. Rompendo Barreiras em um Projeto de Aprendizagem sem Fronteiras. In: TELLES, J.A. Formação Inicial e Continuada de Professores de Línguas: dimensões e ações na pesquisa e na prática. Campinas: Pontes Editores, 2009. Cap. 7, p. 113-135.

GIMENEZ, T. Por Uma Tipologia de Projetos de Formação Continuada de Professores de Inglês. In: TELLES, J.A. Formação Inicial e Continuada de Professores de Línguas: dimensões e ações na pesquisa e na prática. Campinas: Fontes Editores, 2009. p. 137-151.

GORARD, S.; TAYLOR, C. Combining Research Methods in Educational and Social Research. Berkshire: Berkshire Open University Press, 2004.

GORNALL, S.; BURN, M. Coaching and Learning Schools: a practical guide. London: SAGE Publications, 2013.

GOTTESMAN, B. Peer Coaching For Educators. 2. ed. Lanham, US: The Scarecrow Press, 2000.

GREENWOOD, D.J.; LEVIN, M. Reconstruindo as Relações Entre as Universidade e a Sociedade por Meio da Pesquisa-ação. In: DENZIN, N.K.; LINCOLN, Y.S. O Planejamento 
da Pesquisa Qualitativa: teorias e abordagens. Tradução de Sandra Regina Netz. 2. ed. Porto Alegre: Artmed, 2006. p. 91-113.

GRUNDY, S. Action Research at the School Level: possibilities and problems. Educational Action Research, Vol 2 No 1, 1994.

HARGREAVES, A. Teacher Development and Teachers' Work: Issues of Time and Control. Paper presented at the International Conference on Teacher Development, Toronto: [s.n.], 1989.

HATCH, E. (1978). Second language acquisition: A book of readings. Rowley, MA: Newbury House, 1978.

HELB 1. História do Ensino de Línguas no Brasil. Disponível em: $<$ http://www.helb.org.br/index.php?option=com_content\&view=article\&id=63:reformacapanema-pico-na-oferta-de-linguas \&catid=1016:1942\&Itemid=2>. Acesso em: 03. jun. 2015.

HELB 2. História do Ensino de Línguas no Brasil. Disponível em: $<$ http://www.helb.org.br/index.php?option=com_content $\&$ view=article\&id=32:ldb-de1961\&catid=1035:1961\&Itemid=2>. Acesso em: 10. junho 2015.

HELB 3. História do Ensino de Línguas no Brasil. Disponível em: $<$ http://www.helb.org.br/index.php?option=com_content\&view=article\&id=69:publica-dalei-de-diretrizes-e-bases-no-9394\&catid=1041:1996\&Itemid=2>. Acesso em: 10. Jun. 2015.

HOPKINS, D. A Teacher's Guide to Classroom Research. Buckingham: Open University Press, 2002.

HULT, M.; LENNUNG, S. Towards a definition of action-research: a note and bibliography. Journal of Management Studies, 1980, p. 241-250.

ICF. International Coach Federation. Disponivel em: <http://www.coachfederation.org/>. Acesso em: 20. novembro 2014.

JOYCE, B.; SHOWERS, B. Improving Inservice Training: The Messages of Research. Educational Leadership, 1980, p. 379-385.

KEMMIS, K.; MCTAGGART, R. The action research reader. Geelong, Victoria: Deakin University Press, 1988.

Participatory Action Research. In: DENZIN, N.; LINCOLN, Y. Handbook of Qualitative Research. London: Sage, 2000.

KENNEDY, A. Models of Continuing Professional Development: a framework for analysis. Journal of In-Service Education, v. 31, n. 2, 2005, p. 235-250.

KNIGHT, J. Unmistakable Impact: A partnership for Dramatically Improving Instruction. Thousand Oaks, CA: Corwin Press, 2011. 
KOSHY, V. Action Research for Improving Practice: a practical guide. London: Paul Chapman Publishing, 2005.

LANDSBERG, M. The Tao of Coaching. London: HarperCollins, 1996.

MACINTYRE, C. The Art of Action Research in the Classroom. London: David Fulton, 2000.

MARCUSCHI, L.A. Análise da Conversação. São Paulo: Ática, 2003.

MCKERNAN, J. Curriculum Action Research. London: Kogan Page, 1991.

MOK, W.E. Reflecting On Reflections: a case study of experienced and inexperienced. System, Great Britain, 22, 1994, p. 93-111.

MONTEIRO, D.C. Formando Professores de EFL: uma reflexão sobre as décadas de 80 e 90. In: DANIEL, F.G., et al. A Formação de Professores de Línguas: novos olhares. 11. ed. Campinas: Pontes Editores, v. 1, 2011. p. 17-30.

MOURA FILHO, A.C.L. Basta de Clamarmos Inocência: a formação reflexiva do rofessor contemporâneo de línguas. In: SILVA, K.A., et al. A Formação de Professores de Línguas: novos olhares. 11. ed. Campinas: Pontes Editores, v. 1, 2011. p. 49-72.

NELSON, C.; TREICHLER, P.; GROSSBERG, L. Cultural Studies: an introduction. In: NELSON, C.; TREICHLER, P.; GROSSBERG, L. Cultural Studies. New York: Routledge, 1992. p. 1-16.

NOGUEIRA, M.O.S. Práticas Colaborativas na Escola: Coaching e mentoring na (trans) formação do professor de línguas. Brasília: Departamento de Línguas Estrangeiras e Tradução, Universidade de Brasília, 2011, 145 f. Dissertação de Mestrado.

NÓVOA, A. Concepções e Práticas da Formação Contínua de Professores. In: NÓVOA, A. Formação Contínua de Professores: realidade e perspectivas. Aveiro: Universidade de Aveiro, 1991.

PAIVA, V.L.M.O. Avaliação dos cursos de Letras e a formação do professor. Revista do GELNE. João Pessoa. Vol. 5, n. 1 e 2. p. 193-200, 2004. Disponível em: <http://www.veramenezes.com/rgelne.htm>. Acesso em: 23. jan. 2015.

O Novo Perfil dos Cursos de Licenciatura em Letras. In: TOMICH, et (Orgs.). A interculturalidade no ensino de inglês. Florianópolis: UFSC, 2005. p.345-363. Disponível em: <http://www.veramenezes.com/perfil.htm>. Acesso em: 21. jan. 2015.

Memórias de Aprendizagem de Professores de Língua Inglesa. ed. 9 Contexturas, São Paulo, 2006, p.63-78. Disponível em: <http://de.scribd.com/doc/167927077/Contexturas9>. Acesso em: 15. jan. 2015.

PERRENOUD, P. A Prática Reflexiva no Ofício de Professor: Profissionalização e Razção Pedagógica. Porto Alegre: Artemed Editora, 2002. 
PESSOA, R.R. Formação crítica de professores de línguas estrangeiras. In: SILVA, K.A. da.; DANIEL, F. de G.; KANETO-MARQUES, S.M.; SALOMÃO, A.C.B.(Orgs.). A formação de professores de línguas: novos olhares. Volume 1. Campinas: Pontes, 2011. p.31-47.

PIMENTA, S.G. Professor Reflexivo: construindo uma crítica. In: PIMENTA, S.G.; GHEDIN, E. Professor Reflexivo no Brasil: gênese e crítica de um conceito. São Paulo: Cortez, 2005. p. 17-52.

PODSEN, I.J.; DENMARK, V.M. Coaching and Mentoring First-year and Studentteachers. New York: Eye on Education, 2007.

PRABHU, N.S. There is no Best Method - Why? TESOL Quarterly, 1990.

REASON, P.; BRADBURY, H. Handbook of Action Research: participative enquiry and practice. London: Sage, 2001.

RICHARDSON, L. Writing: a method of inquiry. In: DENZIN, N \& LINCOLN, Y. S. (Eds.). Handbook of qualitative research. London: Sage, 1994, p. 516-529.

ROBBINS, P. How to Plan and Implement a Peer Coaching Program. Alexandria: ASCD, 1991.

ROBERTS, A. Homer's Mentor: duties fulfilled or misconstrued. History of Education Journal, v. 64, Novembro 1999.

ROMERO, T.R.D.S. Características lingüísticas do processo reflexivo. In: MAGALHÃES, M.C.C. A Formação do Professor Como um Profissional Crítico: Linguagem e reflexão. Campinas: Mercado das Letras, 2004. p. 189- 202.

ROSA, M.V.D.F.P.D.C.; ARNOLDI, M.A.G. A Entrevista na Pesquisa Qualitativa. Belo Horizonte: Autêntica, 2006.

SABOTA, B.R. Estágio Supervisionado de LE: Um estudo de caso sobre a formação universitária de professores de íngles na UFG. Tese (Doutorado em Letras e Linguística) Faculdade de Letras, Universidade Federal de Goiás, Goiania: [s.n.], 2008.

A Utilização de Diários Dialogados na Formação Universitária de Professores de Inglês: um convite à reflexão. Polyphonía, Goiânia, v. 21/1, p. 153-166, jan./jun. 2010.

SANTOS, L.L.D.C.P. Dimensões Pedagógicas e Políticas da Formação Contínua. In: VEIGA Caminhos da Profissionalização do Magistério. Campinas: Papirus, 1998.

SCHÖN, D.A. The reflective practitioner. New York: Basic Books, 1983.

Educating the reflective practitioner: toward a new design for teaching and learning in the professions. Jossey-Bass Publishers, 1987.

Formar professores como profissionais reflexivos. In: NOVOA, A. Os professores e sua formação. Lisboa: Dom Quixote, 1992. p. 77-92. 
SHOWERS, B. Transfer of Training: the Contribution of Coaching. Eugene: Center for Educational Policy and Management, 1982.

SHOWERS, B.; JOYCE, B. The Evoluation of Peer Coaching. Improving Professional Practice, v. 53, n. 6, 1996, p. 12-16.

SHULMAN, L. Address presented at the Annual Conference of the Association for Supervision and Curriculum Development. San Francisco: [s.n.]. 1991.

SIEGEL, P.H. Using peer mentors during periods of uncertainty. Leadership and Organization, v. 21, n. 5, 2000, p. 243-253.

SILVA, A. Desafios e Prioridades na Formação e Carreira do Professor de Inglês. Revista Contexturas, ISSN 0104-7485, 2013, p. 7-25.

SILVA, T.M.T. Professor Reflexivo e uma Nova (?) Cultura Docente: uma análise a partir dos anos 90. Tese (Doutorado) - UNICAMP. São Paulo: Unicamp, 2005.

SILVEIRA, R.M.H. A Entrevista na Pesquisa em Educação: uma arena de significados. In: COSTA, M.V. Caminhos Investigativos II: outros modos de fazer pesquisa em educação. Rio de Janeiro: DP\&A, 2002. p. 119-141.

SOUZA, A.C.D.; LOPES, C.E. Formação de Professor Pesquisador Reflexivo nas Licenciaturas de Matemática. Sociedade Brasileira de Educação Matemática, 2012. 1-10.

STRINGER, E.T. Action Research. 3. ed. Thousand Oaks: Sage, 2007.

STURM, L. Conhecendo a Realidade Escolar Para uma Formação Inicial Crítica e Reflexiva de Professores de Inglês. In: DANIEL, F. G., et al. A Formação de Professores de Línguas: novos olhares. 11. ed. Campinas: Pontes Editores, v. 1, 2011. p. 73-95.

TÁPIAS-OLIVEIRA, E.M. A Construção da Identidade Profissonal do Professor e a Produção Diarista. In: KLEIMAN, A.; MATÊNICO, M. L. M. Letramento e Formação de Professores: práticas discursivas, representações e construção do saber. São Paulo: Mercado de Letras, 2005. p. 165-179.

TEDESCO, J.C.; FANFANI, E.T. Nuevos Maestros para Nuevos Estudiantes. In: PEARLMAN, M. O. Maestros en América Latina: nuevas perspectivas sobre su formación y desempeno. Washington: Preal, 2004. p. 67-96.

TELlES, J.A. Apresentação. In: TELlES, J. A. Formação Inicial e Continuada de Professores de Línguas: dimensões e ações na pesquisa e na prática. Campinas: Pontes Editores, 2009.

VEZUB, L.F. La Formación y el Desarrollo Profesional Docente Frente a los Nuevos Desafíos de la Escolaridad. Profesorado: Revista de Currículum y Formación del Profesorado, Granada, 11, n. 001, 2007. Disponivel em: <http://www.ugr.es/ recfpro/>. Acesso em: 05. novembro 2014.

VICENTI, P.P.; LUGLI, R.G. História da profissão docente no Brasil: representações em disputa. São Paulo: Cortez, 2009. 
VIEIRA ABRAHÃO, M.H. Tentativas de Construção de Uma Prática Renovada: a formação em serviço em questão. In: ALMEIDA FILHO, J.C.P. O Professor de Língua Estrangeira em Ação. 3. ed. Campinas: Pontes Editores, 2009. p. 29-50.

A Prática de Ensino e o Estágio Supervisionado Como Foco de Pesquisa na Formação do Professor de LE. Contexturas, São Paulo, v. 1, p. 49-54, 1992.

WOLK, L. Coaching: a arte de soprar brasas. Rio de Janeiro: Qualitymark, 2008.

ZEICHNER, K.M. A Formação Reflexiva de Professores: ideias e prática. Tradução de A. J. Carmona Teixeira; Maria João Carvalho e Maria Nóvoa. Lisboa: Educa, 1993.

Educational Action Research. In: REASON, P.; BRADBURY, H. Handbook of Action Research: participative Enquiry and Practice. London: Sage, 2001. 


\section{APÊNDICES}

\section{Apêndice A - Carta-convite à Diretoria da UnB Idiomas}

Brasília, I_ 2014

Prezada diretora

Como requisito parcial para o Programa de Mestrado em Linguística Aplicada da Universidade de Brasília, estou conduzindo um estudo sobre Peer Coaching (orientação entre pares). O objetivo da pesquisa é investigar uma experiência de implementação do Peer Coaching, com o apoio de um líder coach (pesquisador).

Inicialmente, os 4 participantes responderão a um questionário para que sejam coletados seus dados biográficos e sobre sua formação profissional.

A seguir, os participantes serão acompanhados durante três meses, seja em reuniões individuais ou em pares para orientação, seja na sala de aula ou outro espaço da escola apropriado à atividade. Tudo será registrado por meio de gravações e anotações feitas por mim ou por outro participante da pesquisa.

Será reservado aos participantes o direito ao anonimato em todas as informações prestadas. Além disso, eles poderão se retirar do projeto a qualquer momento, se assim desejarem.

A senhora e os professores terão acesso aos resultados antes de serem publicados, e assim, terão a oportunidade de refletir com o pesquisador, manifestando opiniões ou sugerindo modificações.

Peço, portanto, sua permissão para coletar dados no UnB Idiomas. Agradeço antecipadamente sua colaboração e acredito que o desenvolvimento deste trabalho poderá oferecer uma maior compreensão das experiências vividas pelos professores no projeto.

Atenciosamente,

Bernd Renner

Mestrando da Universidade de Brasília 


\section{Apêndice B - Termo de Consentimento Livre e Esclarecido à Diretoria da UnB Idiomas}

\section{Projeto de pesquisa: \\ Investigando os efeitos da implementação de um projeto de Peer Coaching na UnB Idiomas}

$\mathrm{Eu}$,

Coordenadora Geral da UnB Idiomas,

$\mathrm{CPF}$ , concordo que Bernd Renner, Mestrando do Programa de Pós Graduação em Linguística Aplicada da Universidade de Brasília, sob a orientação do Professor Doutor Augusto César Luitgards Moura Filho, colete dados nesta escola, para a pesquisa acima mencionada.

Estou ciente dos objetivos desse estudo e de que a identidade dos professores colaboradores será mantida em anonimato.

Autorizo a coleta de dados conforme especificado na carta-convite.

Brasília, $/ 2014$

Coordenadora Geral do UnB Idiomas 


\section{Apêndice C - Carta-convite ao (à) Professor(a)}

Brasília,_/_/2014

Prezado(a)

Como requisito parcial para o Programa de Mestrado em Linguística Aplicada da Universidade Federal de Brasília, gostaria de conduzir um estudo sobre um projeto de Peer Coaching na UnB Idiomas. Se for de seu consentimento, a coleta de dados será realizada durante o segundo semestre do ano de 2014.

Inicialmente o(a) senhor(a) responderá a um questionário, para que sejam coletados seus dados biográficos e sobre sua formação profisional. A seguir, (a) senhor(a) será acompanhado(a) durante um período de 3 meses, seja em reuniões individuais ou em pares para orientação, seja em sua sala de aula ou qualquer espaço da escola apropriado à realização da atividade. Tudo será registrado por meio de gravações e anotações feitas pelo pesquisador ou pelo outro participante da pesquisa.

Sua colaboração ajudará a documentar e investigar o processo do Peer Coaching, a qual receberá apoio do pesquisador como líder enquanto que os participantes mutuamente assumem o papel de coach e coachee um para o outro a fim de treinar e apoiar um ao outro.

São garantidos os seus direitos ao anonimato e sigilo em relação a todas as informações prestadas. Os resultados de toda a coleta de dados ficarão restritos aos objetivos da pesquisa. $\mathrm{O}$ (a) senhor(a) terá acesso aos resultados antes de serem publicados e oportunidade de refletir sobre eles com o pesquisador, manifestando sua opinião e sugerindo modificações, caso sejam necessárias.

Atenciosamente,

Bernd Renner

Mestrando do Insituto de letras da Universidade Brasília, Brasil 


\section{Apêndice D - Termo de Consentimento Livre e Esclarecido para o(a) Professor(a)}

\section{Projeto de pesquisa: \\ Investigando os efeitos da implementação de um projeto de Peer Coaching na UnB Idiomas}

$\mathrm{Eu}$, $\mathrm{CPF}$

concordo em participar, voluntariamente, da pesquisa do Mestrando Bernd Renner, acima intitulada.

Estou ciente dos objetivos do estudo bem como das necessidades que essa participação implica, disponibilizando-me a atendê- las.

Declaro ter sido devidamente informado(a) de que todas as informações prestadas serão mantidas em sigilo bem como garantido o direito ao anonimato.

Estou ciente, também, de que os dados e os resultados serão utilizados para fins acadêmicos, sendo, portanto, passíveis de publicação e divulgação no meio científico.

Compreendo que posso me retirar do projeto a qualquer momento, se assim o desejar.

Brasília, ____2014

Nome do(a) professor(a) colaborador(a) 


\section{Apêndice E - Roda de Coaching}

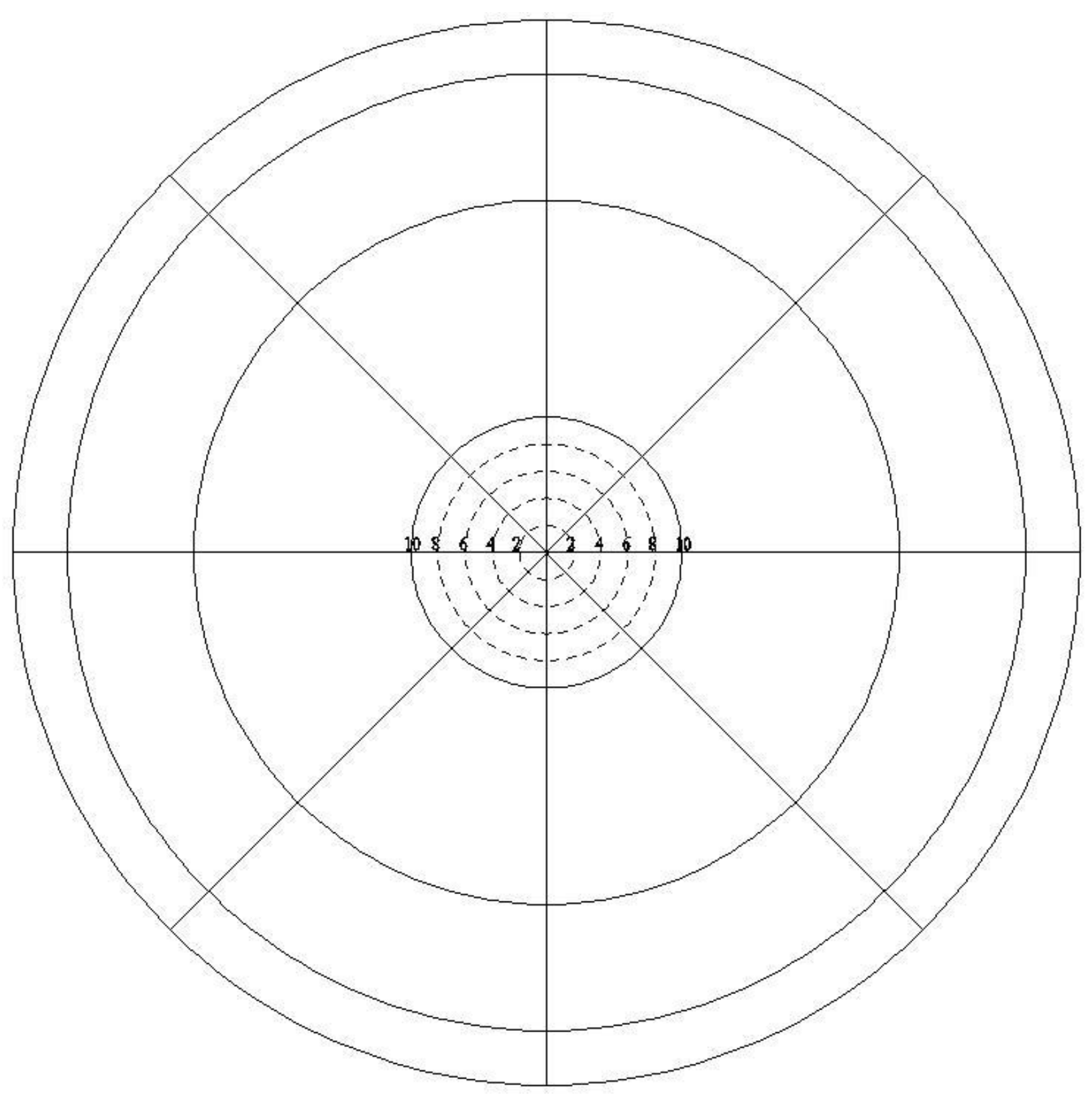

Roda de Coaching - adaptado de Gornall e Burn (2013) 


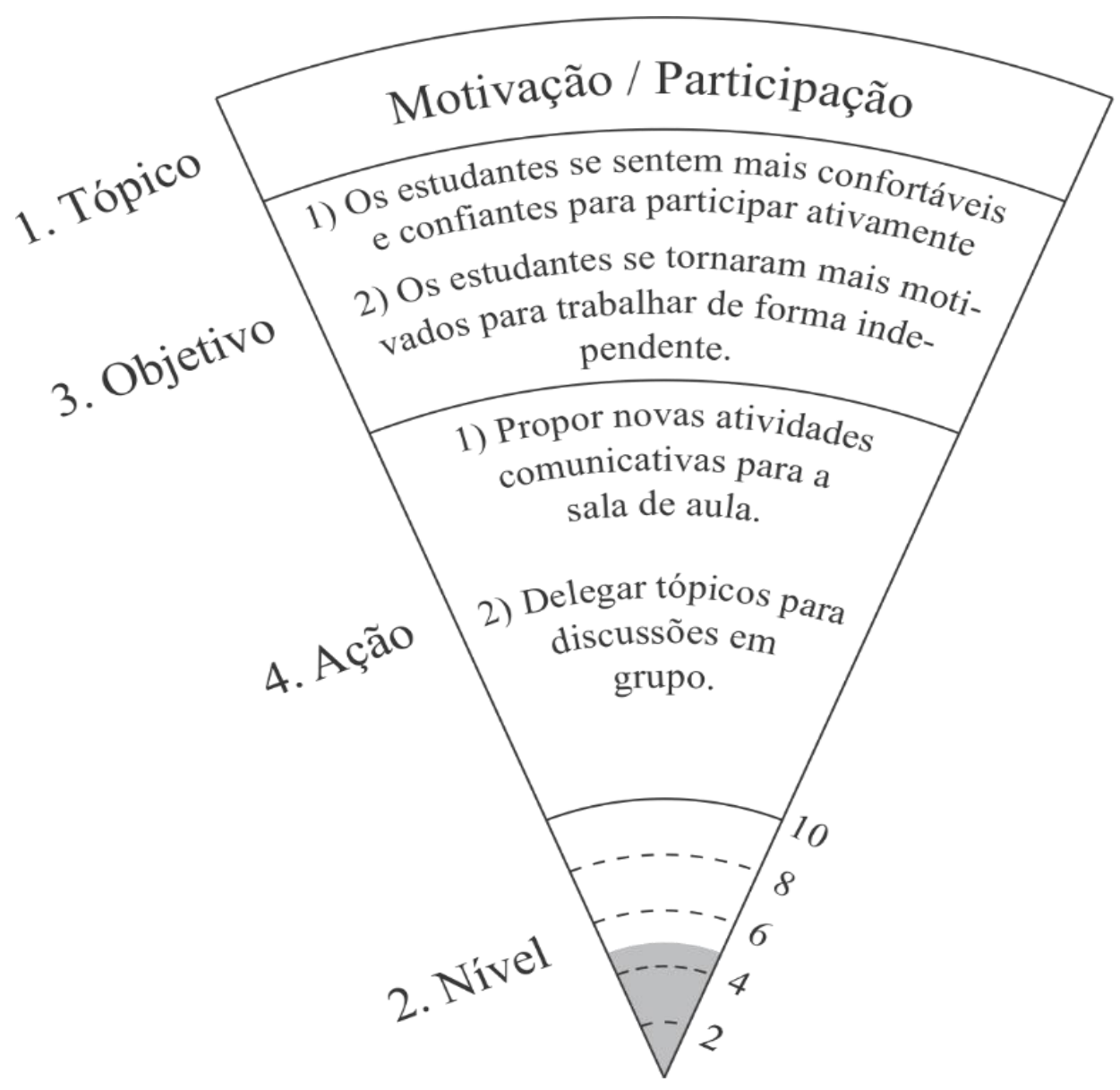

Segmento da roda de coaching - adaptado de Gornall e Burn (2013)

1. Tópico: O círculo externo, a preencher pelo coachee, representa o tópico que ele quer trabalhar;

2. Nível: No círculo central, o coachee avalia seu nível de satisfação no que diz respeito ao tópico;

3. Objetivo: Aqui, o coachee descreve seu objetivo, ou seja, a situação em que ele imagina ser a ideal para alcançar o nível "10”;

4. Ação: $\quad$ O coachee e seu par (o coach) discutem e marcam medidas apropriadas, a fim de alcançarem o objetivo. 


\section{Apêndice F - Autoavaliação do Professor}

\section{Teacher self-assessment form}

\section{Personal Qualities}

- Was my voice clearly audible to all the pupils all of the time?

- Did I speak at the right speed?

- Did I control the level of my own language to what was appropriate for the pupils?

- Did I establish and maintain good rapport with my pupils?

\section{General Shape of the Lesson}

- Did the overall shape and balance of the lesson work out as planned?

- Did I follow the stages of my lesson plan?

- Was there variation in types of activity or was there too much of one activity?

- Did the time each activity took work out as planned?

- Was the pace of each segment appropriate for that type of activity? (Was the presentation too fast? The drilling too slow?)

\section{Materials}

- Were the materials appropriate with regards to the age and level of the class:

- - in terms of their linguistic difficulty?

- - in terms of their functional difficulty and use?

- - in terms of their cultural content?

\section{Classroom Management}

- Did I have any problems in managing the class?

- Were my instructions clear and clearly understood by the pupils?

- Did any re-arrangement of seating, movement of pupils in the classroom, giving out or collecting of books, etc. happen smoothly?

\section{Errors}

- Did I cope effectively with the pupils errors which arose?

\section{Questions}

- Were the questions phrased correctly to get the answers I wanted?

- Were there variety of questions?

(Questions for specific information, for gist, inference, etc.)

- Were my questions properly graded from easy to understand to difficult?

- Did I distribute my questions among the pupils equally? (oral) 


\section{Choral Practice}

- Was there the right amount of choral repetition?

- Did I have full control of the technique?

\section{Checking}

- Did I pay enough attention to each individual in the class?

- Did I check that every pupil had grasped the main teaching point?

\section{Communication}

- Did I give the pupils an opportunity for genuine communication?

- Were the materials, exercises and situations authentic?

Aids

- Was my blackboard clear and well laid out?

- Were my visual aids necessary and clear?

- Were my audio aids necessary and clear?

- Were all the aids used effectively for the purpose envisaged?

- Were they all easy for me to use?

\section{Pupils Response}

- Were all the pupils interested all of the time? (Were there any signs of boredom, restlessness or indiscipline?)

\section{Unexpected}

Were there any unexpected things that I had to cope with?

If so, how well did I cope?

\section{Summary}

Did I succeed in achieving my aim?

Did I actually need to teach what I wanted to teach?

How much did the pupils actually gain from my lesson?

Adaptado de Finocchiaro, M. and M. Bonomo,

The Foreign Language Learner, New York: Regents Publishing Company, 1973. 


\section{Apêndice G - Roteiro de Questionário}

\section{Questionnaire}

Brasília, 2014

Dear participant,

the purpose of this questionary is to collect information about your educational and academic background, as well as your professional experience.

This information will complement the analysis of the research data and it will be important for assessing and understanding those.

Your identity and the data will be kept confidential.

Thank you for your cooperation!

Kind regards,

Bernd Renner, researcher (Master student of the PGLA/UnB) 


\section{PERSONAL DATA}

Name:

Date of birth:

E-mail:

Telephone:

PROFESSIONAL FORMATION AND WORK EXPERIENCE

\begin{tabular}{|c|c|c|c|}
\hline LEVEL & $\begin{array}{c}\text { Type of school } \\
\text { (Private/Public) }\end{array}$ & Name of Institution & (From_r_to__ \\
\hline Fundamental & & & \\
\hline Médio & & & \\
\hline Superior & & & \\
\hline Other & & & \\
\hline
\end{tabular}

4. How many lessons/level/week will you teach this semester, at UnB Idiomas? (Regular/thematic classes)?

Level:

Level:

Level:

Level: lessons/week: lessons/week: lessons/week: lessons/week: regular ( ) thematic( ) regular ( ) thematic( ) regular ( ) thematic( ) - regular ( ) thematic ( ) 


\section{Apêndice H - Roteiro da Primeira Entrevista com as Participantes - realizada no dia 22 de agosto 2014}

1. Vamos falar sobre a formação inicial de professores de inglês aqui no Brasil. Você acha que os conteúdos da licenciatura (Letras/Inglês) cobrem todas as áreas que são relevantes no que diz respeito ao exercício da profissão de professor de inglês? Por quê?

2. Você considera os conteúdos ensinados (teorias, metodologia) atualizados?

3. Ao pensar sobre o seu estágio supervisionado ..

a) você pôde - durante o estágio - aplicar e refletir sobre o que você aprendeu nos três anos anteriores do curso de Letras?

b) você pôde trocar experiências com outros professores (em grupos de debate)?

c) você acha que o estágio ajudou para prepará-lo(a) para sua futura profissão?

4. Você se considera um(a) professor(a) autorreflexivo(a) com relação à sua prática? Por que?

5. Você troca experiências/ideias com outros professores e reflete sobre sua prática em conjunto?

6. Vamos falar um pouco sobre a formação continuada de professores. Você participa de projetos de pesquisa, grupos de estudo ou atividades semelhantes?

7. Você usa literatura ou outros recursos (internet, etc.) a fim de manter-se atualizado(a) sobre os novos desenvolvimentos em sua área?

8. Quais suas associações espontâneas ao ouvir a palavra "coaching"?

9. Você já recebeu algum tipo de treinamento em sua carreira profissional? Qual? Quais foram suas experiências?

10. Você foi informado(a) sobre os princípios e os conteúdos básicos de peer coaching. O que te motiva para participar deste projeto e quais são as suas expectativas?

\section{Obrigado!}




\section{Apêndice I - Roteiro da Segunda Entrevista com as Participantes - realizada no dia 24 de outubro 2014}

1. Ao pensar nas últimas seis semanas, como você se sente sobre o projeto?

2. Considerando as diferentes atividades que foram realizadas até agora, quais você gostou e quais não? Por quê?

3. Considerando as áreas específicas que você inicialmente marcou na "roda de coaching", você acha que as atividades lhe ajudaram a melhorar suas práticas de ensino até o momento? Quais e como?

4. Você considera o diálogo com os comentários do seu peer úteis? Você pode descrever de que forma?

5. Você acha que você já pôde expandir seus conhecimentos e melhorá-los, ou até mesmo aprender novas habilidades durante o projeto? De que forma?

6. Existe alguma coisa que você gostaria de mudar para as próximas semanas? Você tem sugestões ou críticas?

7. Como você classifica sua participação no processo de peer coaching, em uma escala de 1 (baixo) a 5 (alto) (atividades, envolvimento, etc), desde o início do projeto até agora?

\section{Obrigado!}




\section{Apêndice J - Roteiro da Terceira Entrevista com as Participantes - realizada no dia 27 de novembro 2014}

1. Por favor, reflita um momento sobre os últimos três meses. As expectativas que você tinha no início foram cumpridas?

2. De quais aspectos do processo de peer coaching você gostou ou não? Por quê?

3. Em nossa primeira entrevista, falamos sobre a autorreflexão do professor. Sua autorreflexão mudou durante o projeto? Como?

4. Considerando as diferentes áreas que você tinha marcado em sua roda de coaching, quais você pôde melhorar? Como?

5. Como é que você pôde se beneficiar de seu peer, durante os últimos três meses?

6. Você considera peer coaching um instrumento adequado para uma formação continuada de professores? Por quê?

7. Você recomendaria aos seus colegas professores participarem de um projeto de peer coaching? Na sua opinião, isso deveria ser obrigatório para todos os professores ou não? Por que?

8. Você tomaria parte em outro programa de peer coaching, se você tivesse a chance? Por quê?

9. Numa escala de 1 a 5, você poderia tentar avaliar a sua motivação no início do projeto, após a metade do tempo e no final do projeto?

10. Sobre meu papel de pesquisador, como você me avalia neste projeto, em uma escala de 1 a 5 ? (preparação/estrutura do projeto, instruções claras, orientações, etc).

11. Imagine que você tenha a oportunidade de criar, sozinho(a), um projeto de peer coaching para professores de inglês em uma escola de idiomas, o que você faria de maneira similar e/ou diferente da forma como foi feito este projeto?

12. Em uma escala de 1 a 5, por favor, dê uma avaliação desse projeto como um todo!

\section{Obrigado!}




\section{ANEXO - Mini-Saga}

one stopenglish

. $\mathrm{com}$

\section{WRITING LESSON}

\section{Writing a \\ Mini Saga}

\section{What is a Mini Saga?}

A mini saga is a piece of writing which has exactly fifty words, not including the title, which can have up to fifteen words. A mini saga has to tell a story and have a beginning, middle and end. It cannot just be a description of something.

The first mini sagas appeared in 1982 in the Sunday Telegraph, an English newspaper. The Sunday Telegraph announced the idea of the mini saga and held a competition for the best ones.

\section{Why use mini sagas?}

Mini sagas provide an excellent vehicle for a short writing lesson. This is because:

they are easy to read

it is an easy task for the learner to understand

to the learner, writing fifty words does not sound difficult (not at first!)

they focus on accuracy (in the editing stage)

- like all creative writing, they have the potential to be very motivating

Here is a writing lesson plan based on mini sagas.

\section{Lesson Plan}

Level: Pre-intermediate (although the level can easily be adjusted)

Aim: Learners learn about mini sagas and read one, which they try to finish themselves. They then write their own mini saga. Students practice writing skills involved in process writing (brainstorming, draft-writing and editing)

Stage One: Write on the board the word saga. Ask students if they know what a saga is. A saga is a story about a group of people over a long period of time. The film series Star Wars is a saga. Tell them that today they are going to write their own saga, but a special kind of saga, a mini-saga.

Stage Two: Tell them that before they write their own, they are going to read one. Pre-teach any difficult vocabulary (ie dock). There are different ways you could exploit this stage of the lesson, using the sample mini-saga in the appendix below. 


\section{one stopenglish \\ .COII \\ Solutions for English Teaching}

1) Ask the students to read it once, turn it over and tell it to a partner in their own words.

2) Give them the mini saga without the title. Tell them to read it and write a title for it in less than 15 words. Compare titles.

3) Give them the mini saga and take out the last line. Ask them to finish the story with a short sentence. Compare sentences.

Stage Three. Tell the class that that story was a saga of a special kind. It was a mini saga. Explain the background of the mini saga (see above). Tell them that now they are going to write their own mini sagas in pairs. Give each pair a prompt to help them focus their writing. Ask them to brainstorm ideas on a piece of paper for their story.

Two kinds of prompt

- A picture or a painting is a great prompt to get students started. You can find pictures of paintings on the Internet at the following famous museum and art gallery websites. Just click on the link to Collections

\section{$\underline{\text { www.tate.org.uk }}$ \\ www.louvre.fr \\ www.moma.org}

- If you do not have access to the Internet, you could ask students to write their story based on an English proverb (the proverb could serve as a moral to the story, or the title). Here are some proverbs you could use (depending on the level of the class you may have to explain the proverbs):

The early bird catches the worm.

Look before you leap.

A rolling stone gathers no moss.

Out of sight, out of mind.

Never say die.

Let sleeping dogs lie.

Better late than never.

Stage four: Students in pairs write the first draft of a very short story based on their prompt (picture or proverb) and ideas. They don't need to worry about the number of words at this stage.

Stage Five: Ask students to swap stories with another pair. Their task now is to make corrections to the others' story. Tell them to look for spelling, grammar and punctuation mistakes. Have a dictionary on hand to help them. Circulate and help pairs as needed.

(c) onestopenglish 2002

Taken from the writing section in www.onestopenglish.com 


\section{one stopenglish \\ .COII \\ Solutions for Ennlish Teaching}

Stage Six: The pairs return the corrected drafts to each other. Now the students should prepare the final draft. They must (1) rewrite the story with corrections and (2) make sure it is between 48 and 52 words exactly (if you think they are up to the challenge, tell them to adhere strictly to the rule of 50 words!) They must also give their mini saga a title.

Stage Seven: Put the mini sagas with their corresponding titles and prompts around the class. Direct students to read each others' mini sagas. You could have the class vote on which is the best one. 


\section{Appendix 1:}

\section{one st op english \\ Solutions for English Teaching}

Sample mini-saga:

\section{WAITING FOR FATE}

The girl said she was going to come back.

The boy promised to wait.

He sat on the dock and waited.

One day while he was waiting he noticed another girl sitting and looking out to sea.

"Are you waiting too?" he asked.

"Not anymore," she said.

They both smiled. 